Argonne

\title{
Decommissioning of the Remediation Systems at Waverly, Nebraska, in 2011-2012
}

\section{Environmental Science Division}


About Argonne National Laboratory

Argonne is a U.S. Department of Energy laboratory managed by UChicago Argonne, LLC under contract DE-AC02-06CH11357. The Laboratory's main facility is outside Chicago, at 9700 South Cass Avenue, Argonne, Illinois 60439. For information about Argonne and its pioneering science and technology programs, see www.anl.gov.

\section{Availability of This Report}

This report is available, at no cost, at http://www.osti.gov/bridge. It is also available on paper to the U.S. Department of Energy and its contractors, for a processing fee, from:

U.S. Department of Energy

Office of Scientific and Technical Information

P.O. Box 62

Oak Ridge, TN 37831-0062

phone (865) 576-8401

fax (865) 576-5728

reports@adonis.osti.gov

\section{Disclaimer}

This report was prepared as an account of work sponsored by an agency of the United States Government. Reference herein to any specific commercial product, process, or service by trade name, trademark, manufacturer, or otherwise, does not necessarily constitute or imply its endorsement, recommendation, or favoring by the United States Government or any agency thereof. The views and opinions of document authors expressed herein do not necessarily state or reflect those of the United States Government or any agency thereof, Argonne National Laboratory, or UChicago Argonne, LLC. 


\section{Decommissioning of the Remediation Systems at Waverly, Nebraska, in 2011-2012}

by

Applied Geosciences and Environmental Management Section

Environmental Science Division, Argonne National Laboratory

June 2012

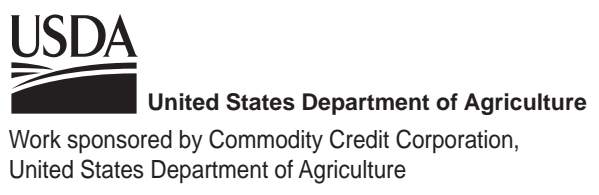




\section{Contents}

Notation.

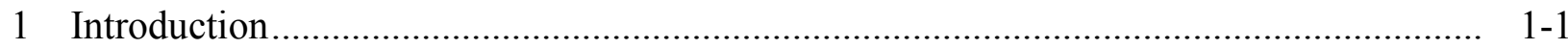

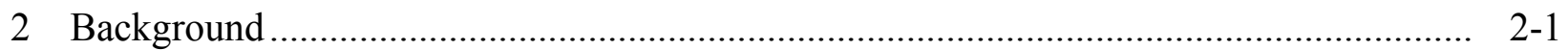

2.1 History of Contamination ..........................................................................

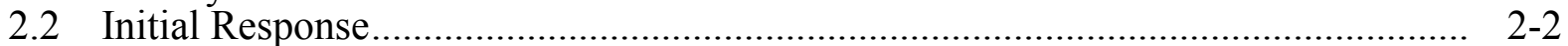

2.3 Performance Criteria ........................................................................................ 2-2

2.4 Treatment Systems and Early Operations ........................................................ 2-3

2.5 Additional Investigation and System Modifications........................................... 2-5

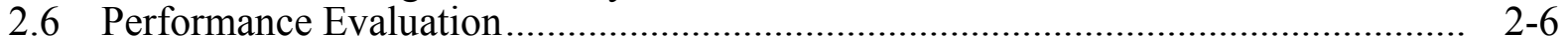

2.7 Targeted Investigations and Well Installations in 2004-2006 ............................. 2-6

2.8 Termination of Treatment System Operations ................................................... 2-7

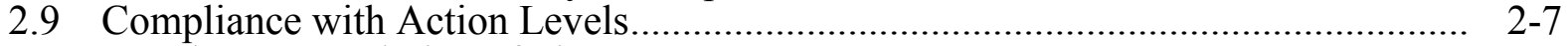

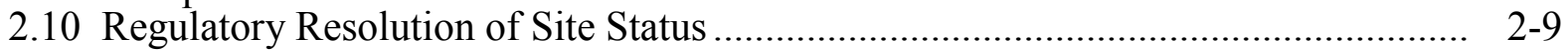

3 Decommissioning of the Remediation Systems ................................................. $3-1$

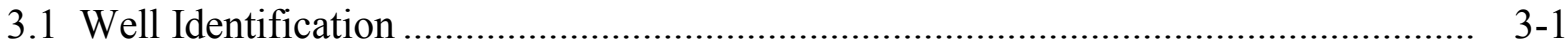

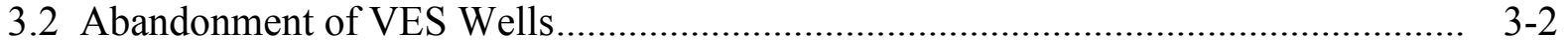

3.3 Abandonment of Groundwater Wells ............................................................. 3-2

3.4 Decommissioning of the Air Stripping System ................................................ $3-2$

3.5 Reconditioning of the Former Treatment Building .......................................... $3-3$

3.6 Beneficial Use of the Property Formerly Overlying the Groundwater Plume............. 3-3

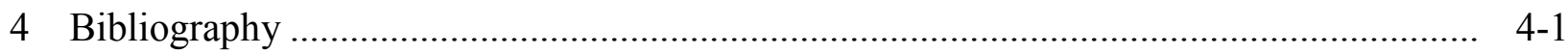

Appendix A: U.S. Environmental Protection Agency Summary, Waverly Ground Water Contamination Site, Nebraska, EPA ID\# NED980862718 ................... A-1

Appendix B: Photographs of the Decommissioning Effort......................................... B-1

Appendix C: Notice of Water Well Decommissioning Forms......................................... C-1

\section{Tables}

2.1 Performance criteria specified in the ROD .................................................. 2-10

2.2 Groundwater pumping summary for the remediation at Waverly .......................... 2-11

2.3 Timeline of site characterization and remediation activities ................................ 2-12 


\section{Figures}

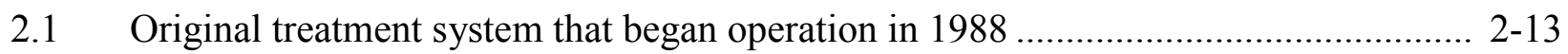

2.2 Locations of the components of the treatment and monitoring systems sitewide ........ 2-14

2.3 Locations of system components on and near the former CCC/USDA property ......... 2-15

3.1 Excavation of the cement vault for the SGWEX well ….......................................... 3-4

3.2 Former SGWEX area after well decommisioning .................................................... 3-4

3.3 Stainless steel air stripper tower in the treatment building ........................................ 3-5

3.4 Plastic spheres used for air exchange inside the air stripper tower............................ 3-5

3.5 Removal of one of the packed-column air stripping towers through the roof of the treatment building ..................................................................................................... 3-6

3.6 Removal of the second tower.............................................................................. 3-6

3.7 Dismantling of the tower support structures inside the treatment building ................. 3-7

3.8 Removal of concrete platforms inside the treatment building .................................... 3-7

3.9 Interior of the treatment building after removal of all equipment .............................. 3-8

3.10 Treatment building before and after decommissioning ........................................... 3-8

3.11 Contaminated area after redevelopment ……................................................... $3-9$ 


\section{Notation}

$\begin{array}{ll}\text { BGL } & \text { below ground level } \\ \text { CCC } & \text { Commodity Credit Corporation } \\ \text { EPA } & \text { U.S. Environmental Protection Agency } \\ \mathrm{ft} & \text { foot (feet) } \\ \mathrm{g} / \mathrm{s} & \text { gram(s) per second } \\ \mathrm{gpm} & \text { gallon(s) per minute } \\ \mathrm{GWEX} & \text { groundwater extraction well } \\ \mu \mathrm{g} / \mathrm{L} & \text { microgram(s) per liter } \\ \mu \mathrm{g} / \mathrm{m}^{3} & \text { microgram(s) per cubic meter } \\ \mathrm{MCL} & \text { maximum contaminant level } \\ \mathrm{mg} / \mathrm{kg} & \text { milligram(s) per kilogram } \\ \mathrm{mi} & \text { mile(s) } \\ \mathrm{MW} & \text { monitoring well } \\ \text { NDEQ } & \text { Nebraska Department of Environmental Quality } \\ \text { NPDES } & \text { National Pollutant Discharge Elimination System } \\ \text { NPL } & \text { National Priority List } \\ \text { PWS } & \text { public water supply } \\ \text { ROD } & \text { Record of Decision } \\ \text { SGMW } & \text { soil gas monitoring well } \\ \text { SGWEX } & \text { supplementary groundwater extraction well } \\ \text { USDA } & \text { U.S. Department of Agriculture } \\ \text { VES } & \text { vapor extraction system } \\ \text { VOC } & \text { volatile organic compounds }\end{array}$




\section{Decommissioning of the Remediation Systems at Waverly, Nebraska, in 2011-2012}

\section{Introduction}

The Commodity Credit Corporation of the U.S. Department of Agriculture (CCC/USDA) operated a grain storage facility in Waverly, Nebraska, from 1952 to 1974. During this time, the grain fumigant " $80 / 20$ " (carbon tetrachloride/carbon disulfide) was used to preserve stored grain. In 1982, sampling by the U.S. Environmental Protection Agency (EPA) found carbon tetrachloride contamination in the town's groundwater. After an investigation of the contaminant distribution, the site was placed on the National Priority List (NPL) in 1986, and the CCC/USDA accepted responsibility for the contamination. An Interagency Compliance Agreement between the EPA and the CCC/USDA was finalized in May 1988 (EPA 1990).

The EPA (Woodward-Clyde Consultants, contractor) started immediate cleanup efforts in 1987 with the installation of an air stripper, a soil vapor extraction system, a groundwater extraction well, and groundwater and soil gas monitoring wells (Woodward-Clyde 1986, 1988a,b). After the EPA issued its Record of Decision (ROD; EPA 1990), the CCC/USDA (Argonne National Laboratory, contractor) took over operation of the treatment systems. The CCC/USDA conducted a site investigation (Argonne 1991, 1992a,b), during which a carbon tetrachloride plume in groundwater was discovered northeast of the former facility. This plume was not being captured by the existing groundwater extraction system.

The remediation system was modified in 1994 (Argonne 1993) with the installation of a second groundwater extraction well to contain the contamination further. Subsequently, a detailed evaluation of the system resulted in a recommendation to pump only the second well to conserve water in the aquifer (Argonne 1995). Sampling and analysis after implementation of this recommendation showed continued decreases in the extent and concentrations of the contamination with only one well pumping (Argonne 1999).

The CCC/USDA issued quarterly monitoring reports from 1988 to 2009. Complete documentation of the CCC/USDA characterization and remediation efforts, including the quarterly monitoring reports, is on the compact disc inside the back cover of this report.

The EPA reported on the progress of the remediation systems in a series of five-year reviews (EPA 1993, 1999, 2004, 2009). These reports and other EPA documentation are also on 
the compact disc inside the back cover of this report, along with the Woodward-Clyde (1986, 1988a,b) documentation cited.

Starting in 2006, the analytical results for groundwater (the only medium still being monitored) showed no carbon tetrachloride concentrations above the maximum contaminant level (MCL) of $5.0 \mu \mathrm{g} / \mathrm{L}$. Because the cleanup goals specified in the ROD (EPA 1990) had been met, the EPA removed the site from the NPL in November 2006 (Appendix A).

In 2008 the National Pollutant Discharge Elimination System (NPDES) permit for the remediation system was deactivated, and a year later the EPA released its fourth and final fiveyear report (EPA 2009), indicating that no further action was required for the site and that the site was ready for unlimited use.

In 2011-2012, the CCC/USDA decommissioned the remediation systems at Waverly. This report documents the decommission process and closure of the site. 


\section{Background}

Waverly is located in southeastern Nebraska, approximately 10 mi northeast of Lincoln, in Lancaster County, Township 11 North, Range 8 East. The population of the city of Waverly was approximately 3,300 in 2009. The former CCC/USDA property is located along the south side of Oldfield Street, just west of North 141st Street. The legal description of the former CCC/USDA property is Lot 158, I.T., in the SW 1/4 of Section 16, Township 11 North, Range 8 East of the 6th Prime Meridian, Lancaster County, Nebraska.

Since 1975, the former CCC/USDA facility property has been owned by Lancaster County, which operates a district office and maintenance facilities on the premises. Parts of the property are covered by massive piles of road maintenance and construction materials, as well as graveled parking areas. Until recently, the land immediately north of the property had been used primarily for agriculture. A new subdivision constructed in 2008 now lies to the northeast.

The city of Waverly obtains all of its drinking water supply from municipal wells that tap the groundwater aquifer. The principal near-surface aquifer in the Waverly area occurs in fluvial sands deposited in a bedrock paleovalley. At the former CCC/USDA facility, the aquifer is divided into an upper zone and a lower zone, separated by a clay layer.

\subsection{History of Contamination}

The grain storage facility operated by the CCC/USDA in 1952-1974 consisted of approximately 100 bins and 13 Quonset huts on concrete foundations. The fumigant 80/20 (carbon tetrachloride and carbon disulfide, with possible traces of chloroform) was used at the facility in approximately 1955-1965 (EPA 1990).

In 1982, the EPA sampled the Waverly municipal wells as part of a nationwide survey and found that public water supply wells PWS-1 and PWS-3 were contaminated with carbon tetrachloride (up to $200 \mu \mathrm{g} / \mathrm{L}$ ) and chloroform (up to $7.5 \mu \mathrm{g} / \mathrm{L}$ ). Public wells PWS-1 and PWS-2 were placed on standby status, while PWS-3 was taken out of service. Additional municipal wells were subsequently installed outside the known extent of the contamination (EPA 1990). 
The former CCC/USDA grain storage facility was identified as the source of the carbon tetrachloride contamination, on the basis of an evaluation of groundwater data, soil gas analyses, and past grain fumigation practices. Concentrations of carbon tetrachloride and chloroform in private wells around the former CCC/USDA facility were as high as $3,120 \mu \mathrm{g} / \mathrm{L}$ and $37 \mu \mathrm{g} / \mathrm{L}$, respectively, in June 1984 (EPA 1990).

On October 15, 1984, because of the contamination, the EPA proposed the site for placement on the NPL. The listing became final on June 10, 1986 (Appendix A).

\subsection{Initial Response}

In May 1986, the EPA developed an Engineering Evaluation and Cost Analyses report (Woodward-Clyde 1986) outlining an expedited response action that included groundwater extraction and treatment with air stripping technology, plus soil gas extraction. Design of the system was completed in May 1987, and system operation began in February 1988 (EPA 1990). Under a compliance agreement that went into effect in May 1988, the CCC/USDA took over the operation and maintenance of the remedial system in June 1988. The ROD (EPA 1990) identified the CCC/USDA as the only potentially responsible party for the site.

The remedial action objectives were as follows (EPA 1990):

- Prevent potential exposure to contaminated groundwater.

- Protect uncontaminated groundwater for future use by preventing further migration of the contaminated groundwater plume.

- Restore the aquifer for future use as a source of drinking water by reducing the contaminant concentrations below health-based criteria.

\subsection{Performance Criteria}

The ROD (EPA 1990) established the following performance criteria: 
- For groundwater, concentrations of $5.0 \mu \mathrm{g} / \mathrm{L}$ for carbon tetrachloride and $3.8 \mu \mathrm{g} / \mathrm{L}$ for chloroform.

- For soil gas, combined carbon tetrachloride and chloroform concentrations of $6.5 \mu \mathrm{g} / \mathrm{m}^{3}$.

- For combined volatile emissions of carbon tetrachloride and chloroform from the vapor extraction system and air stripper system, a rate of $0.147 \mathrm{~g} / \mathrm{s}$.

- For air stripper effluent discharged to surface water, concentrations of $6.95 \mu \mathrm{g} / \mathrm{L}$ for carbon tetrachloride and $5.0 \mu \mathrm{g} / \mathrm{L}$ for chloroform.

- For soil, concentrations of $1.1 \mathrm{mg} / \mathrm{kg}$ for carbon tetrachloride and $1.7 \mathrm{mg} / \mathrm{kg}$ for chloroform.

These performance criteria and the monitoring requirements are summarized in Table 2.1.

\subsection{Treatment Systems and Early Operations}

The treatment systems that began operating in 1988 involved a single groundwater extraction (GWEX) well to capture contaminated groundwater and pipes to carry the water to a packed-tower air stripping system for treatment and removal of carbon tetrachloride and chloroform. The other facet of treatment was a vapor extraction system (VES) that volatilized and extracted contaminants from the soil gas (Figure 2.1).

The air stripping system was designed to accept - from the GWEX well, at a flow rate of $400 \mathrm{gpm}$ - water containing initial concentrations of 4,000 $\mu \mathrm{g} / \mathrm{L}$ (carbon tetrachloride) and $360 \mu \mathrm{g} / \mathrm{L}$ (chloroform), and to remove $99.9 \%$ of the contaminants. After it was pumped to a flow distributor at the top of the stripper, the water cascaded down through a bed of inert packing material. Clean air entered the bottom of the column and was driven upward through the packing material and water to the top of the column. The result was transfer of the volatile organic compounds (VOCs) from the water to the air. The air and VOCs exited the system through a 
stack extending to $41 \mathrm{ft}$ above grade. Emissions from the stack were not to exceed the performance standard of $0.147 \mathrm{~g} / \mathrm{s}$ (Table 2.1).

The treated effluent water from the air stripper was discharged to the ditch north of the former CCC/USDA facility and flowed westward via drainage ditches to Salt Creek. The maximum permitted contaminant concentrations in the discharge water were regulated under an NPDES permit, as specified by the Nebraska Department of Environmental Control (now the Nebraska Department of Environmental Quality [NDEQ]). The effluent standards were $6.95 \mu \mathrm{g} / \mathrm{L}$ for carbon tetrachloride and $5.0 \mu \mathrm{g} / \mathrm{L}$ for chloroform (Table 2.1). The CCC/USDA sampled the discharged water monthly, as required by the NPDES permit and the ROD (EPA 1990).

The GWEX well was installed on the north edge of the former CCC/USDA facility, in the area of maximum groundwater contamination. The well was screened over two intervals: 19-34 ft and 39-49 ft below ground level (BGL). The GWEX well was designed to have a zone of influence of 1,000-1,400 ft when pumping at $150 \mathrm{gpm}$ (EPA 1990). The locations of the treatment system and monitoring installations are shown in Figures 2.2 and 2.3.

Public well PWS-3 and the Hedrick south private well (Figure 2.2) were approximately $900 \mathrm{ft}$ and 1,200 ft from the GWEX well, respectively. In 1990, the carbon tetrachloride concentration in PWS-3 was below $5.0 \mu \mathrm{g} / \mathrm{L}$, while the Hedrick well showed concentrations of $20-50 \mu \mathrm{g} / \mathrm{L}$. As of January 1990, the only monitoring well with detectable contaminant concentrations was MW2A (Figure 2.3), a shallow well on the former CCC/USDA property (EPA 1990).

Seventeen VES wells were installed in the vadose zone above the water table, at depths of 27-29 ft BGL, with the lower 15-20 ft screened. A blower sized for an air flow rate of 160 cubic feet per minute created a vacuum in these wells. Air drawn through the soil induced the transfer of VOCs from solution into the vapor phase. The contamination was then drawn into the VES wells and exited the system from the tops of the air stripping towers described above. The radius of influence for each VES well was approximately $100 \mathrm{ft}$. The combined contaminant emissions from the VES and the air stripping system were not to exceed the performance standard of $0.147 \mathrm{~g} / \mathrm{s}$ (Table 2.1). Five nested soil gas monitoring wells (SGMWs; each with shallow, intermediate, and deep screens) were installed to monitor the progress of the VES system. 


\subsection{Additional Investigation and System Modifications}

In the fall of 1991, the CCC/USDA conducted additional site investigation activities to verify the downgradient performance of the GWEX well and to characterize the hydrogeologic setting in greater detail. Three additional monitoring wells (MW6A, MW6B, MW6C) were installed (Figure 2.3). This 1991 investigation identified a plume of carbon tetrachloride and chloroform in groundwater to the northeast of the former facility, along 141st Street and beyond the radius of influence of the existing GWEX well. This contamination was believed to have migrated from the former facility before the treatment systems began operation. Maximum concentrations detected were approximately $400 \mu \mathrm{g} / \mathrm{L}$ (carbon tetrachloride) and $200 \mu \mathrm{g} / \mathrm{L}$ (chloroform). No contamination was detected along Waverly Road, approximately 0.5 mi north of Oldfield Road and the former CCC/USDA facility (Argonne 1992a).

The results of the 1991 investigation demonstrated that the treatment systems were effective in controlling contaminant migration and were progressing toward cleanup and restoration of the aquifer. However, the newly identified plume northeast of the former CCC/USDA facility needed to be captured and treated to achieve the objectives of the ROD (EPA 1990).

To capture the northeast contaminant plume, a supplementary groundwater extraction (SGWEX) well was proposed, to be located approximately $1,735 \mathrm{ft}$ north of the centerline of Oldfield Street, along 141st Street, with a pumping rate of $150 \mathrm{gpm}$. The capture zone of the SGWEX well, which was estimated to extend about $800 \mathrm{ft}$ to the east and west, was expected to merge with the capture zone of the existing GWEX well. The SGWEX well would address the contamination at the Hedrick south private well, which had been unaffected by the GWEX at that point. Three additional monitoring wells were proposed to monitor the northeast contaminant plume and the effectiveness of the SGWEX remediation (Argonne 1993).

The three proposed monitoring wells (MW9, MW10, MW11; Figure 2.2) were installed in 1993 (Argonne 1995). The SGWEX was installed in 1994, along with a pipeline to transport the extracted water to the process building for treatment by air stripping. With the 1994 installation of the SGWEX and piping, the Waverly site achieved the EPA status of "construction complete" (EPA 2006a). The SGWEX continued operation until September 2004 (Argonne 2004b). Over the lifetime of the remediation project, the extraction wells discharged more than 1 billion gallons of groundwater (Table 2.2). 


\subsection{Performance Evaluation}

The GWEX was shut down in April 1995, and the SGWEX continued to operate alone. An evaluation in 1997 of the effectiveness of the solo SGWEX operation resulted in adjustments to the SGWEX pumping rate (Argonne 1999). A second performance evaluation led to bypassing of the air stripper and elimination of its operation in September 1999. The water produced by the SGWEX had carbon tetrachloride and chloroform concentrations below the respective NPDES discharge limits, and the air stripper was no longer needed (Argonne 1999).

\subsection{Targeted Investigations and Well Installations in 2004-2006}

Until April 2004, efforts to complete delineation of the groundwater plume were hampered by the lack of access to the Hedrick property. To determine the carbon tetrachloride distribution in this key area, the CCC/USDA proposed a targeted investigation (Argonne 2003). After access was arranged and the investigation was complete, the results demonstrated that carbon tetrachloride contamination was restricted stratigraphically to a laterally continuous, welldeveloped sand package in the upper sandy units of the local aquifer system. Carbon tetrachloride concentrations of 1.6-36 $\mu \mathrm{g} / \mathrm{L}$ were identified in this sand package, in a relatively narrow plume originating near the eastern part of the former facility and extending northward toward the SGWEX well. Carbon tetrachloride concentrations exceeding the MCL of $5.0 \mu \mathrm{g} / \mathrm{L}$ were limited to an area approximately $950 \mathrm{ft}$ long. Carbon tetrachloride was not detected in the deeper portion of the aquifer, below the sandy unit (Argonne 2004a).

In November 2004, the CCC/USDA (Argonne 2004b) recommended installation of four additional monitoring wells: MW5E and MW12 on county property along 141st Street (in the northeast plume), plus MW13 and MW14 east of 141st Street, in agricultural fields owned by Aspen Builders and targeted for residential development. Wells MW5E and MW12 were installed in the summer of 2005, but access could not be negotiated for installation of proposed wells MW13 and MW14. The installation of wells MW5E and MW12 was documented in the quarterly report for July-September 2005 (on the compact disc inside the back cover of this report).

Because proposed wells MW13 and MW14 could not be installed, the EPA requested recommendations for a one-time groundwater sampling event on the Aspen Builders property. The purpose was to determine whether contaminant migration had shifted to the northeast after 
pumping of the SGWEX well was discontinued in 2004. After access was arranged, the sampling was conducted at six locations on February 8-10, 2006, by using the track-mounted cone penetrometer unit. The samples contained no detectable carbon tetrachloride. The results were documented in the quarterly report for January-March 2006 (on the compact disc inside the back cover of this report).

\subsection{Termination of Treatment System Operations}

On the basis of the findings of the 2004 targeted investigation (Argonne 2004a) and under the terms of the ROD (EPA 1990), the EPA authorized the CCC/USDA to begin the final technical and regulatory activities required to achieve closure of the remedial action and to accomplish removal of the site from the NPL (Gilmore 2004). Operation of the treatment systems was terminated as follows, with the approval of the EPA (2006a):

- Operation of the VES was discontinued in 1993.

- Operation of the GWEX well ended in 1995.

- Operation of the air stripper ended in 1999.

- Operation of the SGWEX well was terminated on September 2, 2004.

\subsection{Compliance with Action Levels}

By 2006, cleanup goals had been achieved, and a final inspection had been completed (EPA 2006a). The following compliance milestones had been achieved as a result of the operation of the remedial systems, beginning in 1988 (EPA 2006b):

- Compliance was achieved for the combined air emissions standard for carbon tetrachloride and chloroform $(0.147 \mathrm{~g} / \mathrm{s})$ from the VES and air stripper system. The CCC/USDA discontinued operation of the VES in 1993 on the basis of achieving action levels. Overall compliance with the air standard was approved by the EPA in 1995. 
- Compliance was achieved with surface water standards $(6.95 \mu \mathrm{g} / \mathrm{L}$ for carbon tetrachloride and $5.0 \mu \mathrm{g} / \mathrm{L}$ for chloroform). After action levels were achieved, the air stripper system was shut down in 1999 (with EPA approval), and discharge to surface water ceased.

- Compliance was achieved with the groundwater standards $(5.0 \mu \mathrm{g} / \mathrm{L}$ for carbon tetrachloride and $3.8 \mu \mathrm{g} / \mathrm{L}$ for chloroform) for all compliance points in the original plume addressed by the GWEX well. The GWEX well was shut down in 1995, with EPA approval, after action levels were achieved in this portion of the plume.

- Compliance was achieved with groundwater standards $(5.0 \mu \mathrm{g} / \mathrm{L}$ for carbon tetrachloride and $3.8 \mu \mathrm{g} / \mathrm{L}$ for chloroform) for all compliance points (Table 2.1) in the remaining northeastern plume addressed by the SGWEX well. The SGWEX was shut down in 2004, with EPA approval, after action levels had been achieved throughout the entire plume.

The compliance status of soil and soil gas was resolved as follows:

- Action levels for soil were set at $1.1 \mathrm{mg} / \mathrm{kg}$ for carbon tetrachloride and $1.7 \mathrm{mg} / \mathrm{kg}$ for chloroform. Because the initial soil samples collected were in compliance with the action levels, no additional soil sampling was required.

- The soil gas compliance criterion defined in the ROD (EPA 1990) was a combined action level of $6.5 \mu \mathrm{g} / \mathrm{m}^{3}$ for carbon tetrachloride and chloroform, based on "acceptable concentrations for indoor air" as specified by the Agency for Toxic Substances and Disease Registry for residential basements (risk factor $=10^{-4}$ and hazard index $\mathrm{H}=1$ ). This criterion did not account for the soil gas-to-air attenuation factor, which can range from 0.01 to 0.001 depending of site conditions. A reevaluation the soil gas results using EPA (2002) guidance indicated that the contaminants were at sufficient depth (30-35 ft BGL) to make vapors unlikely to reach potential receptors. Consequently, no complete pathways and no potential risks to human health were associated with the soil gas levels. On this basis, the EPA issued an 
Explanation of Significant Differences (EPA 2005) deleting the soil gas compliance criterion established in the ROD (EPA 1990).

Quarterly sampling from 2007 to 2009 continued to indicate that the concentrations of carbon tetrachloride and chloroform were below the groundwater standards $(5.0 \mu \mathrm{g} / \mathrm{L}$ for carbon tetrachloride and $3.8 \mu \mathrm{g} / \mathrm{L}$ for chloroform) in monitoring wells MW5 and MW9, in the contaminated area.

\subsection{Regulatory Resolution of Site Status}

The Final Remedial Action Report, issued in June 2006 (EPA 2006a), was prepared in accordance with the EPA's Close Out Procedures for National Priorities List Sites (OSWER Directive 9320.2-09A-P). The EPA (2006a) report documented that the remedial action had been completed, cleanup goals had been achieved, and a final inspection had been completed. Subsequently, the August 2006 Final Close Out Report (EPA 2006b) documented that the cleanup goals established by the ROD (EPA 1990) had been achieved.

On September 19, 2006, with NDEQ concurrence, EPA Region VII published a Notice of Intent to Delete (Federal Register Notice FRL-8220-3). The EPA had determined that the responsible parties had implemented all appropriate actions, and therefore no further remedial actions were needed. The Notice of Intent to Delete defined a public comment period, to close on October 19, 2006 (http://www.epa.gov/superfund/sites/npl/noids/i060919.pdf).

As a result of its determination that compliance had been achieved, the EPA issued a Direct Final Notice of Deletion on November 20, 2006 (Federal Register Notice FRL-8220-4; http://www.epa.gov/superfund/sites/npl/d061120.htm).

In 2008 the NPDES permit was deactivated, and a year later the EPA (2009) released its final five-year report, indicating that no further monitoring was required for the site, and the site was ready for unlimited use.

Table 2.3 is a summary of activities at the site through the years. The EPA's summary for the Waverly Ground Water Contamination Site (ID NED980862718) is in Appendix A (and online at http://www.epa.gov/region07/cleanup/npl_files/ned980862718.pdf). 
TABLE 2.1 Performance criteria specified in the ROD (EPA 1990).

\begin{tabular}{|c|c|c|c|c|c|c|}
\hline \multirow[b]{2}{*}{ Medium } & \multirow[b]{2}{*}{ Compliance Point } & \multicolumn{2}{|c|}{ Action Level } & \multicolumn{2}{|c|}{ Monitoring Frequency } & \multirow[b]{2}{*}{ Compliance Period } \\
\hline & & $\begin{array}{c}\text { Carbon } \\
\text { Tetrachloride }\end{array}$ & Chloroform & $\begin{array}{c}\text { Initial Period, } \\
\text { Beginning 4/1/1988 }\end{array}$ & Long Term & \\
\hline \multirow[t]{2}{*}{ Air } & $\begin{array}{l}\text { Combined VOCs } \\
\text { emissions from VES and } \\
\text { air stripper system }\end{array}$ & \multicolumn{2}{|c|}{$0.147 \mathrm{~g} / \mathrm{s}$ (combined) } & Monthly for first quarter & Quarterly & During all operations \\
\hline & Ambient air & \multicolumn{2}{|c|}{$\begin{array}{c}0.125 \mu \mathrm{g} / \mathrm{m}^{3} \text { above background } \\
\text { (combined) }\end{array}$} & $\begin{array}{l}\text { Summer 1988; seasonal } \\
\text { monitoring to be discussed } \\
\text { after May } 1988\end{array}$ & As required & Not applicable \\
\hline Groundwater & All on-site monitoring wells & $5.0 \mu \mathrm{g} / \mathrm{L}$ & $3.8 \mu \mathrm{g} / \mathrm{L}$ & $\begin{array}{l}\text { Monthly if above action } \\
\text { level; other wells one time } \\
\text { during first quarter }\end{array}$ & $\begin{array}{l}\text { Quarterly if above } \\
\text { action level; other } \\
\text { wells annually }\end{array}$ & $\begin{array}{l}1 \text { year ( } 4 \text { events) } \\
\text { after GWEX wells } \\
\text { are off }\end{array}$ \\
\hline $\begin{array}{l}\text { Surface } \\
\text { water }\end{array}$ & $\begin{array}{l}\text { Air stripping system } \\
\text { discharge }^{a}\end{array}$ & $6.95 \mu \mathrm{g} / \mathrm{L}$ & $5.0 \mu \mathrm{g} / \mathrm{L}$ & Monthly for first quarter & Monthly & During all operations \\
\hline Soil & $\begin{array}{l}\text { Former federal grain } \\
\text { facility }\end{array}$ & $1.1 \mathrm{mg} / \mathrm{kg}$ & $1.7 \mathrm{mg} / \mathrm{kg}$ & Not applicable ${ }^{b}$ & Not applicable ${ }^{\mathrm{b}}$ & Not applicable \\
\hline Soil gas & $\begin{array}{l}\text { SGMW 1-5 (A, B, C) and } \\
\text { all VES wells }\end{array}$ & $6.5 \mu \mathrm{g} / \mathrm{m}^{3}($ & nbined) ${ }^{d}$ & $\begin{array}{l}\text { Monthly if above action } \\
\text { level; otherwise one time } \\
\text { during first quarter }\end{array}$ & $\begin{array}{l}\text { Quarterly if above } \\
\text { action level; otherwise } \\
\text { annually }\end{array}$ & 1 year (4 events) \\
\hline
\end{tabular}

\footnotetext{
a Air stripper system discharge was to be maintained at $\mathrm{pH}$ 6-9.

b Initial soil samples indicated that soils were in compliance with the action level; no additional sampling was anticipated.

c Individual VES wells were to be isolated from the VES system when concentrations were below the action level.

d The soil gas criterion was deleted by the Explanation of Significant Differences (EPA 2005).
} 
TABLE 2.2 Groundwater pumping summary for the remediation at Waverly.

\begin{tabular}{|c|c|c|c|}
\hline \multirow[b]{2}{*}{ Year } & \multicolumn{3}{|c|}{ Water Pumped (gal/yr) } \\
\hline & GWEX & SGWEX & Total \\
\hline 1988 & $15,030,000$ & & $15,030,000$ \\
\hline 1989 & $51,197,400$ & & $51,197,400$ \\
\hline 1990 & $46,828,400$ & & $46,828,400$ \\
\hline 1991 & $47,132,400$ & & $47,132,400$ \\
\hline 1992 & $45,513,880$ & & $45,513,880$ \\
\hline 1993 & $64,188,000$ & & $64,188,000$ \\
\hline 1994 & $51,121,440$ & $39,991,680$ & $91,113,120$ \\
\hline 1995 & $11,836,800$ & $50,391,360$ & $62,228,160$ \\
\hline 1996 & & $50,768,640$ & $50,768,640$ \\
\hline 1997 & & $44,645,760$ & $44,645,760$ \\
\hline 1998 & & $82,607,520$ & $82,607,520$ \\
\hline 1999 & & $83,124,453$ & $83,124,453$ \\
\hline 2000 & & $87,240,490$ & $87,240,490$ \\
\hline 2001 & & $76,221,526$ & $76,221,526$ \\
\hline 2002 & & $81,663,006$ & $81,663,006$ \\
\hline 2003 & & $63,239,890$ & $63,239,890$ \\
\hline 2004 & & $15,758,297$ & $15,758,297$ \\
\hline Totals & $332,848,320$ & $675,652,622$ & $1,008,500,942$ \\
\hline
\end{tabular}


TABLE 2.3 Timeline of site characterization and remediation activities.

\begin{tabular}{|c|c|}
\hline Date & Event \\
\hline $1952-1974$ & CCC/USDA grain storage operation. \\
\hline $1955-1965$ & Use of grain fumigant "80/20" at CCC/USDA facility. \\
\hline 1982 & EPA sampling finds carbon tetrachloride contamination in public wells. \\
\hline 1984 & EPA proposes site for NPL list (10/15/84). \\
\hline 1986 & EPA places site on NPL (06/10/86). \\
\hline 1987 & $\begin{array}{l}\text { EPA conducts a preliminary assessment, remedial investigation/feasibility study, and site } \\
\text { inspection. }\end{array}$ \\
\hline 1987 & EPA issues notice letters $(03 / 18 / 87)$. \\
\hline 1987 & $\begin{array}{l}\text { EPA has installed GWEX, VES, air stripper, soil gas monitoring wells, and groundwater } \\
\text { monitoring wells. Groundwater wells sampled: MW1A, MW1B, MW1C, MW2A, MW3A, MW4A, } \\
\text { MW4B, MW5A, MW5B, MW5D, MW7A, MW8A. }\end{array}$ \\
\hline 1988 & USDA-EPA compliance agreement formalized (05/27/88); CCC/USDA takes responsibility. \\
\hline 1990 & EPA issues ROD $(09 / 26 / 90)$. \\
\hline 1991 & CCC/USDA studies begin. Wells MW6A, MW6B, MW6C installed. \\
\hline 1993 & Wells MW9, MW10, MW11 installed. SGWEX installed. VES operation discontinued (08/13/93). \\
\hline 1993 & EPA five-year review (09/27/93). \\
\hline 1994 & SGWEX operation begins (end of March 1994). \\
\hline 1995 & GWEX operation discontinued (04/14/95). \\
\hline 1995 & SGMW sampling discontinued after March 1995. \\
\hline 1999 & EPA five-year review (09/30/99). \\
\hline 1999 & Air stripper shut down and bypassed (September 1999). \\
\hline 2004 & SGWEX operation discontinued $(09 / 02 / 04)$ \\
\hline 2004 & EPA five-year review, including groundwater and soil gas sampling (09/28/04). \\
\hline 2004 & Targeted groundwater sampling on Hedrick property. \\
\hline 2005 & $\begin{array}{l}\text { EPA issues Explanation of Significant Differences, which deletes the soil gas compliance criterion } \\
\text { in the } 1990 \text { ROD (03/10/05). }\end{array}$ \\
\hline 2005 & $\begin{array}{l}\text { Wells MW5E and MW12 installed. Installation of MW13 and MW14 prevented by access } \\
\text { problems. }\end{array}$ \\
\hline 2006 & $\begin{array}{l}\text { Cone penetrometer sampling on Aspen property ENE of the former facility, because of inability to } \\
\text { gain access for installing wells MW13 and MW14. }\end{array}$ \\
\hline 2006 & EPA issues closeout report $(08 / 02 / 06)$ \\
\hline 2006 & EPA deletes site from NPL (11/20/06). \\
\hline 2008 & NPDES reporting requirements terminated; NPDES permit deactivated. \\
\hline 2009 & $\begin{array}{l}\text { EPA releases report of five-year review }(08 / 13 / 09) \text {. No further monitoring is required; site is ready } \\
\text { for unlimited use. }\end{array}$ \\
\hline 2011-2012 & Decommissioning of remediation systems. \\
\hline
\end{tabular}




\section{SCHEMATIC OF REMEDIAL ACTION TREATMENT SYSTEM}

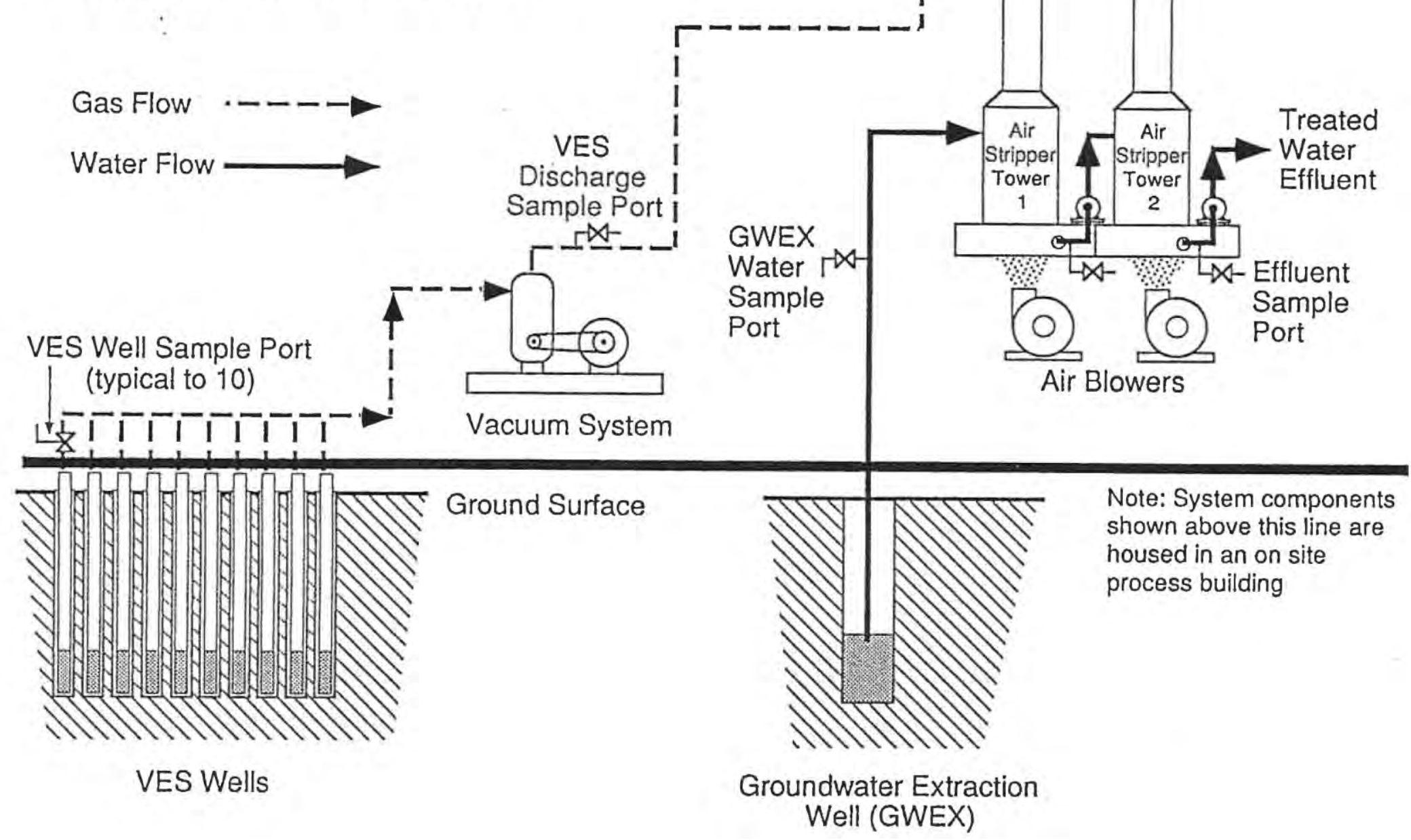

FIGURE 2.1 Original treatment system that began operation in 1988. 


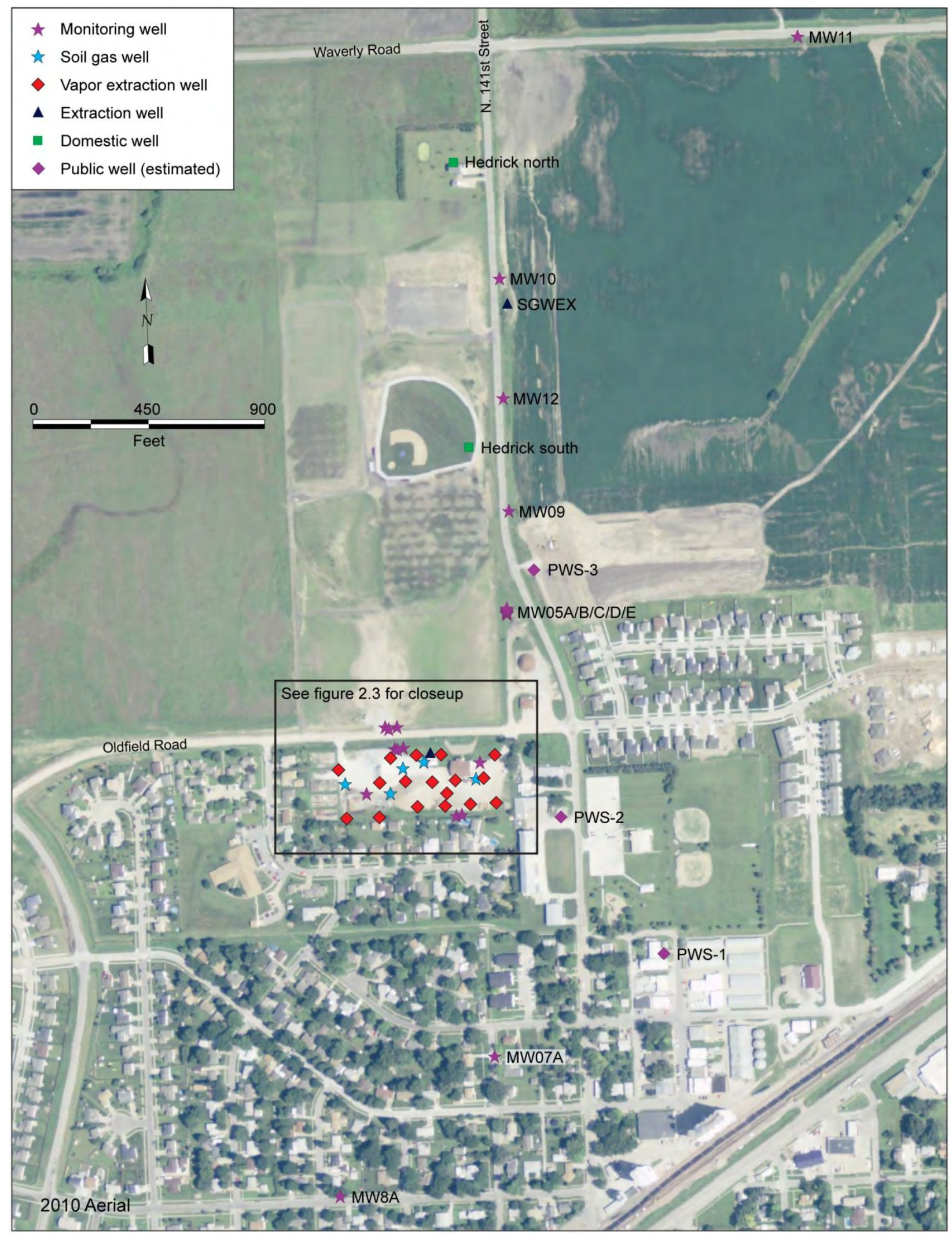

FIGURE 2.2 Locations of the components of the treatment and monitoring systems sitewide. Source of aerial photograph: FSA (2010). 


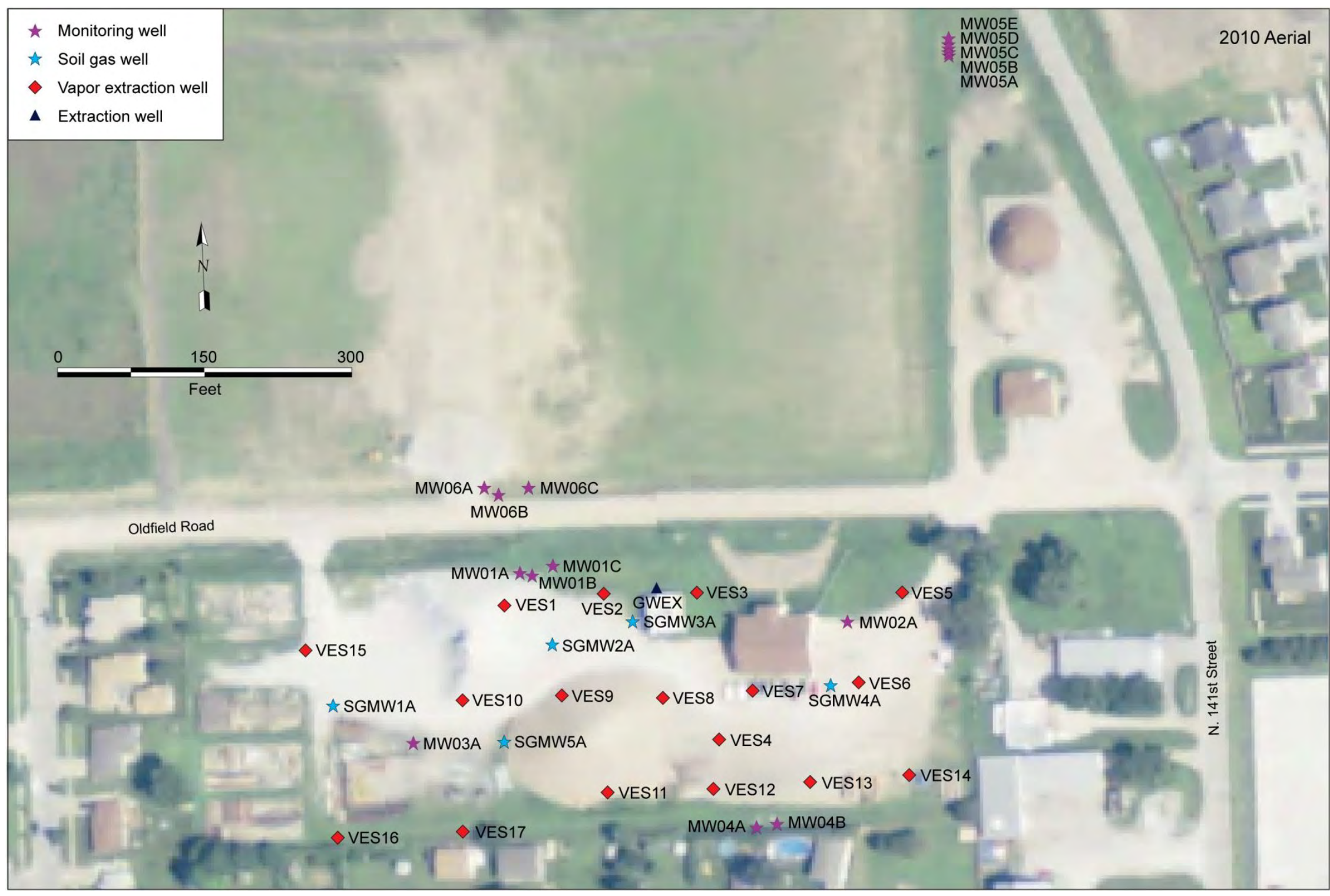

FIGURE 2.3 Locations of system components on and near the former CCC/USDA property. Source of aerial photograph: FSA (2010). 


\section{Decommissioning of the Remediation Systems}

\subsection{Well Identification}

The multistage decommissioning process at Waverly began in February 2011 with a site visit and initial identification of monitoring wells, vapor extraction wells, and groundwater extraction wells. In some cases, the well locations shown in the early maps developed by the EPA and its contractors were incorrect. Many of the VES wells were under large piles of road materials (sand and gravel) used by the Lancaster County Department of Roads in its operations. Lancaster County is the current owner of the property formerly occupied by the CCC/USDA facility.

In June 2011, excavators were used to remove and relocate the road materials, trace the VES piping network, and locate additional VES wells. In all, 17 VES wells, 5 soil gas monitoring well clusters (3 wells per cluster), 2 groundwater extraction wells, and 21 groundwater monitoring wells (including clusters) were located. These represented all of the borings originally installed at Waverly.

The wells located were as follows:

- Vapor extraction system wells: VES1-VES17

- $\quad$ Soil gas monitoring wells: $\quad$ SGMW1A-C, SGMW2A-C, SGMW3A-C, SGMW4A-C, SGMW5A-C

- Groundwater extraction wells: GWEX, SGWEX

- Groundwater monitoring wells: MW1A, MW1B, MW1C, MW2A, MW3A, MW4A, MW4B, MW5A, MW5B, MW5C, MW5D, MW5E, MW6A, MW6B, MW6C, MW7, MW8, MW9, MW10, MW11, MW12

Photographs of selected wells as they were located in the field are in Appendix B. 


\subsection{Abandonment of VES Wells}

Each of the 17 VES points was plugged in June 2011 according to Nebraska regulations. Tom Christopherson was on-site during this time, observing the operations. Christopherson is the program manager for the Water Well Standards and Contractor's Licensing Program for the Nebraska Department of Health and Human Services.

\subsection{Abandonment of Groundwater Wells}

During the period July 11-25, 2011, all of the groundwater monitoring wells and the GWEX and SGWEX wells (Section 3.1) were plugged and abandoned, and the extraction well vaults were removed. All wells were decommissioned in accord with NDEQ regulations. Well abandonment documents (Appendix C) were filed with the State of Nebraska on August 16, 2011. Figure 3.1 shows the removal of the SGWEX well vault (in progress), and Figure 3.2 shows the same area after regrading and dressing of the surface. Additional photographs of removal of the SGWEX well are in Appendix B.

\subsection{Decommissioning of the Air Stripping System}

Consultation with the CCC/USDA led to a determination that salvaging of the air stripping system as a whole (or even most of its individual components) for further use was not viable. Decommissioning of the dual packed-column air stripping towers and the associated pumps and piping therefore began in November 2011 and was completed in December 2011. Before the system was dismantled, each component (and any water remaining therein) was sampled and analyzed for carbon tetrachloride and/or chloroform. No unacceptable contamination was identified. The steel and aluminum recovered from the system were either recycled (to the extent possible, as scrap metal) or discarded in a manner acceptable to the CCC/USDA and the NDEQ.

Figure 3.3 and Figure 3.4, respectively, show, one of the stainless steel stripping towers and the associated packing medium (plastic framework spheres). Figure 3.5 and Figure 3.6 illustrate removal of the towers and their vent stacks through the opened roof of the treatment building. Figure 3.7 shows the dismantling of the tower support structures in the treatment building. 


\subsection{Reconditioning of the Former Treatment Building}

After removal of the air stripper and all related treatment system equipment, the concrete base that had supported these units was removed (Figure 3.8), and the concrete floor was repaired (Figure 3.9). The recovered concrete rubble was accepted by the Lancaster County Department of Roads for use as rip-rap construction material. A new roof was installed, and all unnecessary vents etc. in the walls of the building were repaired. Figure 3.10 shows the process building prior to decommissioning of the treatment system and after the reconditioning was completed in December 2011. Ownership of the building was transferred to Lancaster County in January 2012, completing the on-site closeout activities.

\subsection{Beneficial Use of the Property Formerly Overlying the Groundwater Plume}

The land overlying the carbon tetrachloride plume was an agricultural field during treatment. Now that cleanup is complete and unlimited use is allowed, that land has been sold and redeveloped for housing and recreation, including athletic fields and an airport for radiocontrolled hobby aircraft. These developments are visible to the north of Oldfield Road in the 2010 aerial photograph in Figure 3.11. 


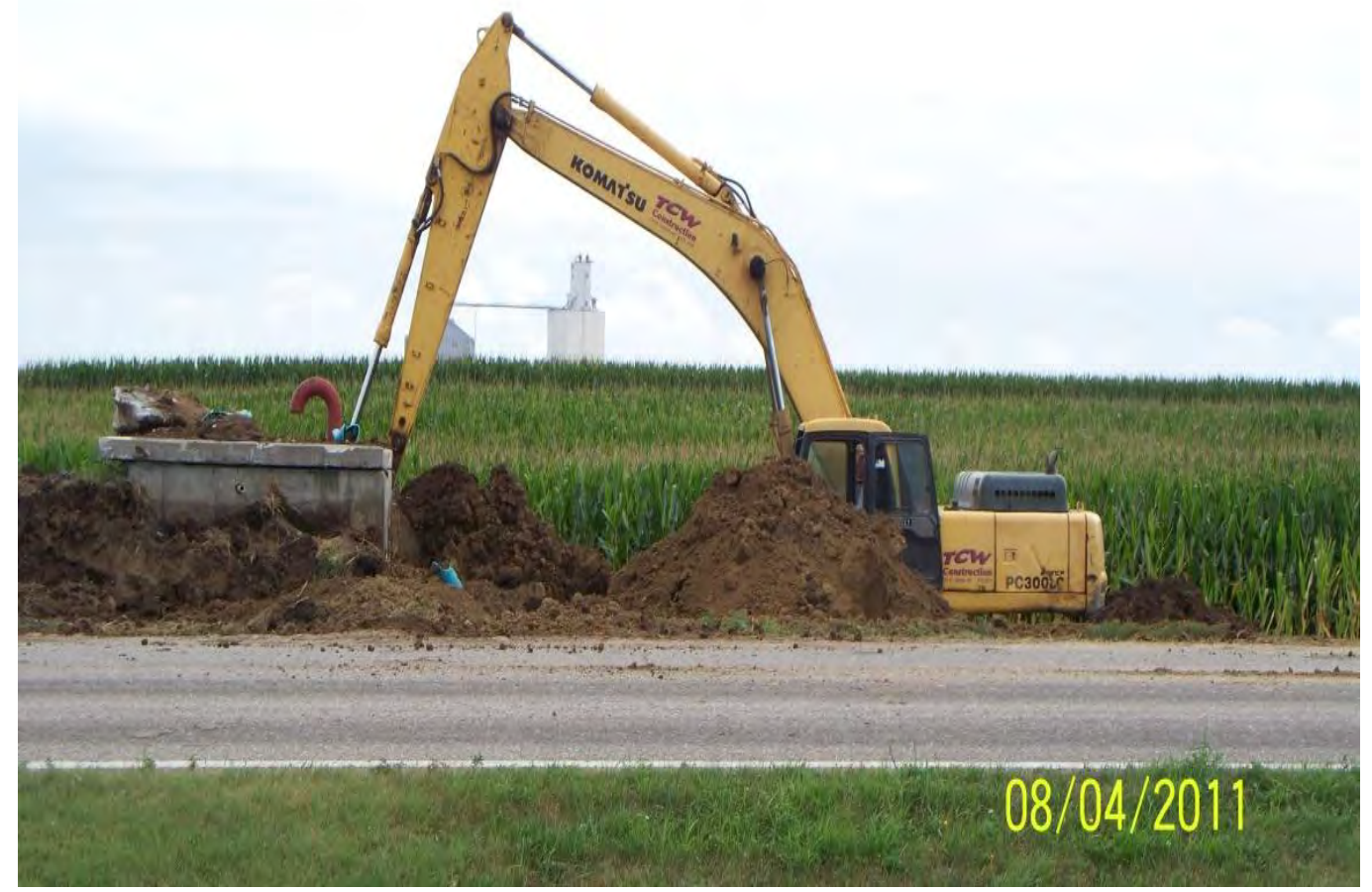

FIGURE 3.1 Excavation of the cement vault for the SGWEX well.

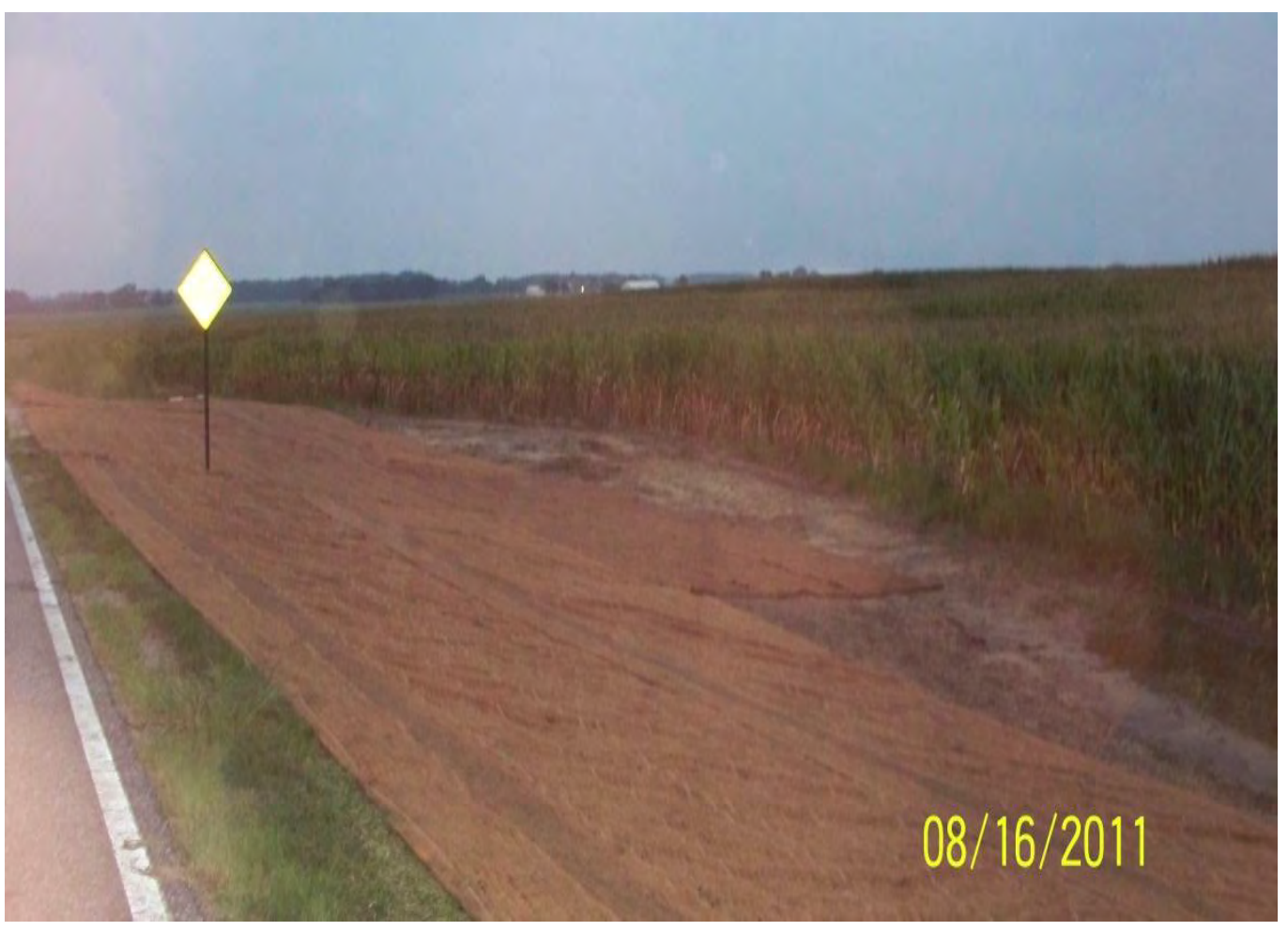

FIGURE 3.2 Former SGWEX area after well decommisioning. 


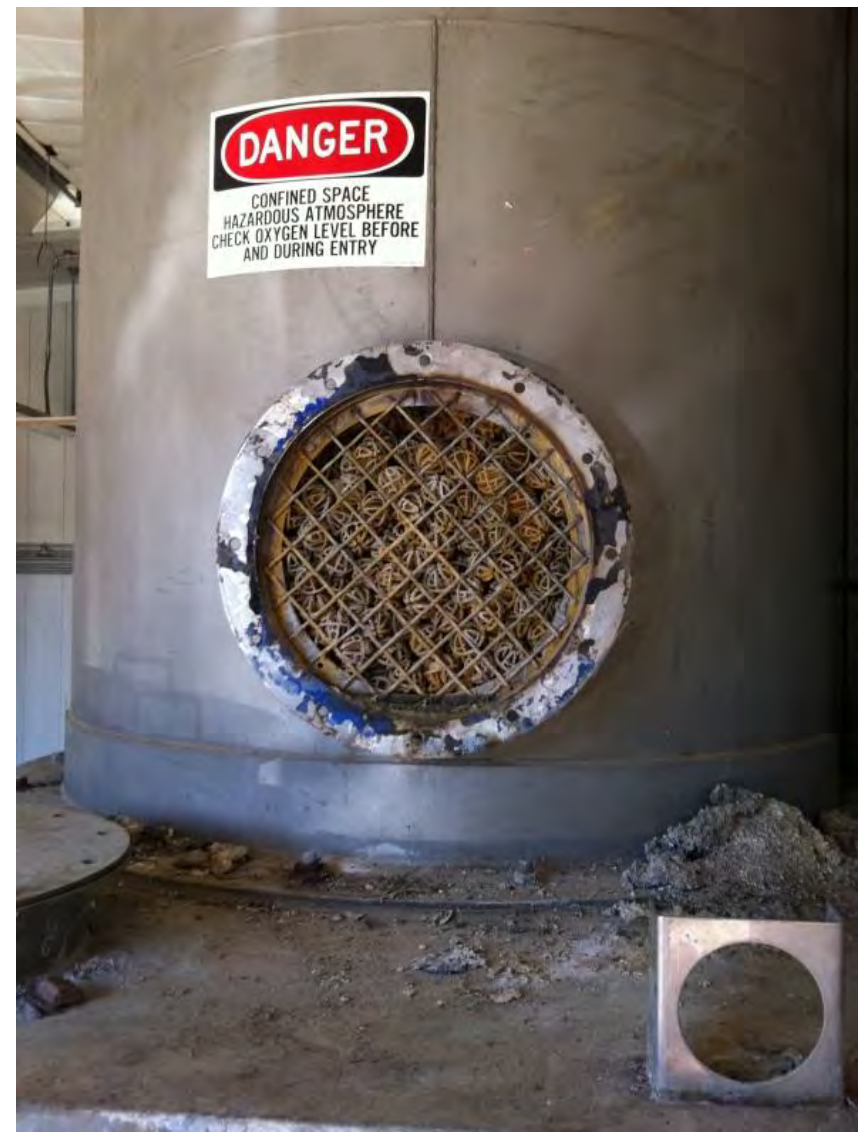

FIGURE 3.3 Stainless steel air stripper tower in the treatment building.

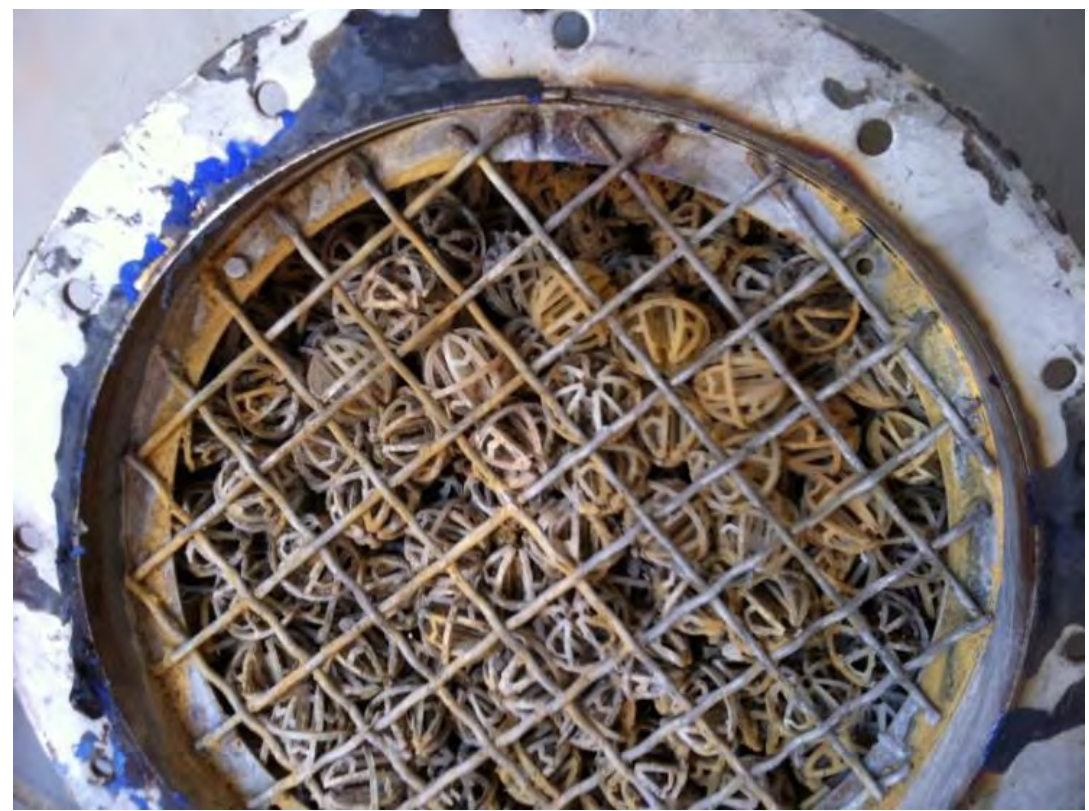

FIGURE 3.4 Plastic spheres used for air exchange inside the air stripper tower. 


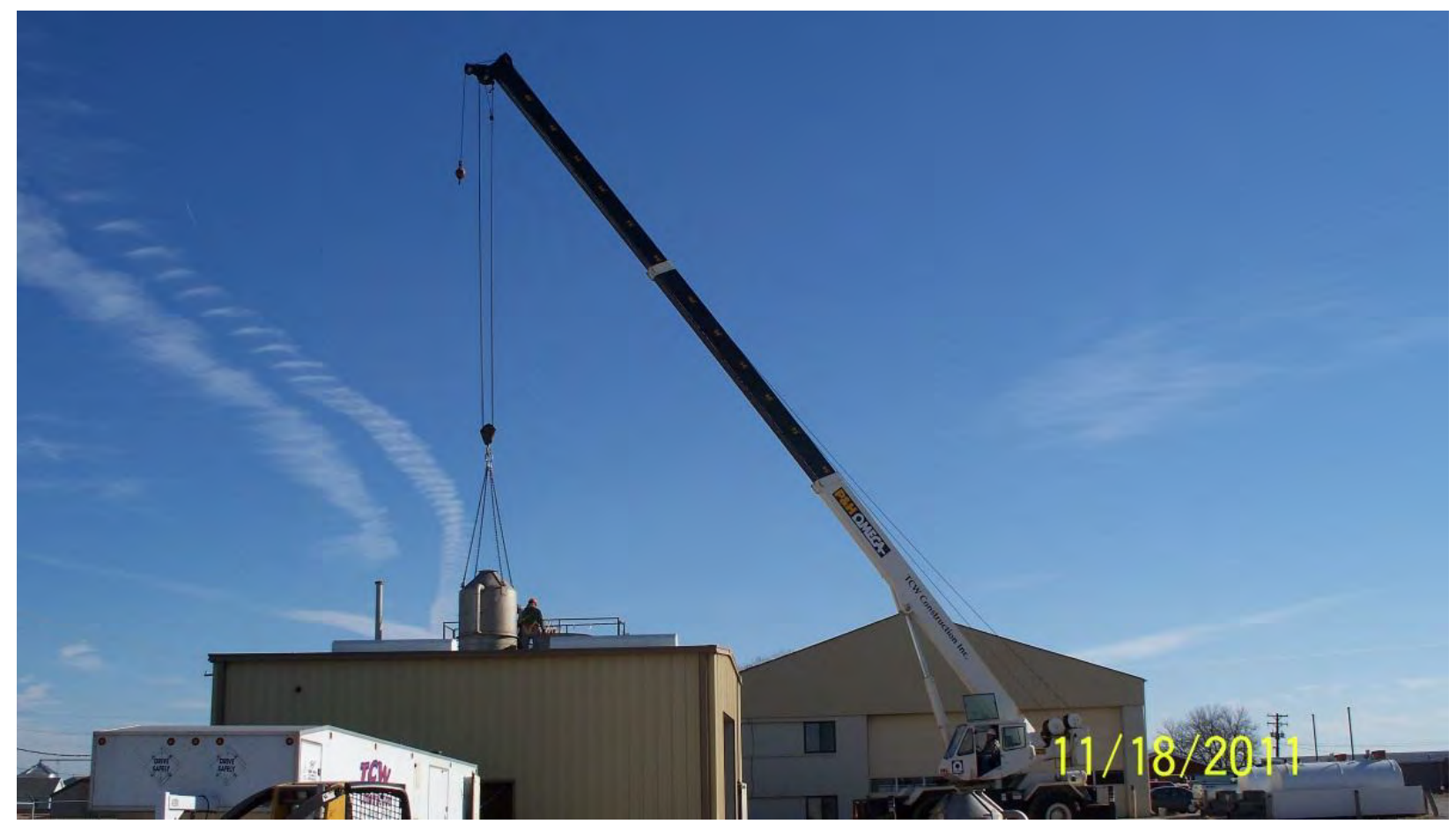

FIGURE 3.5 Removal of one of the packed-column air stripping towers through the roof of the treatment building.

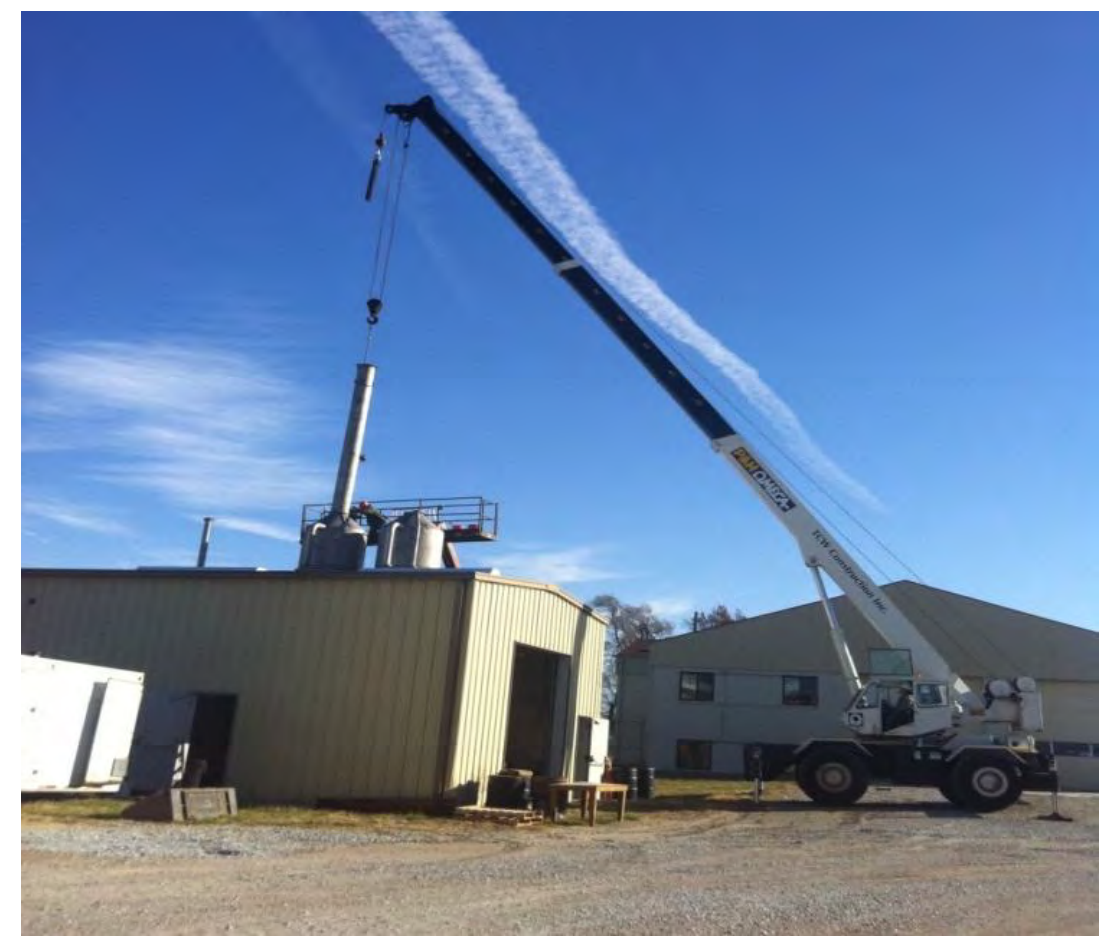

FIGURE 3.6 Removal of the second tower. 


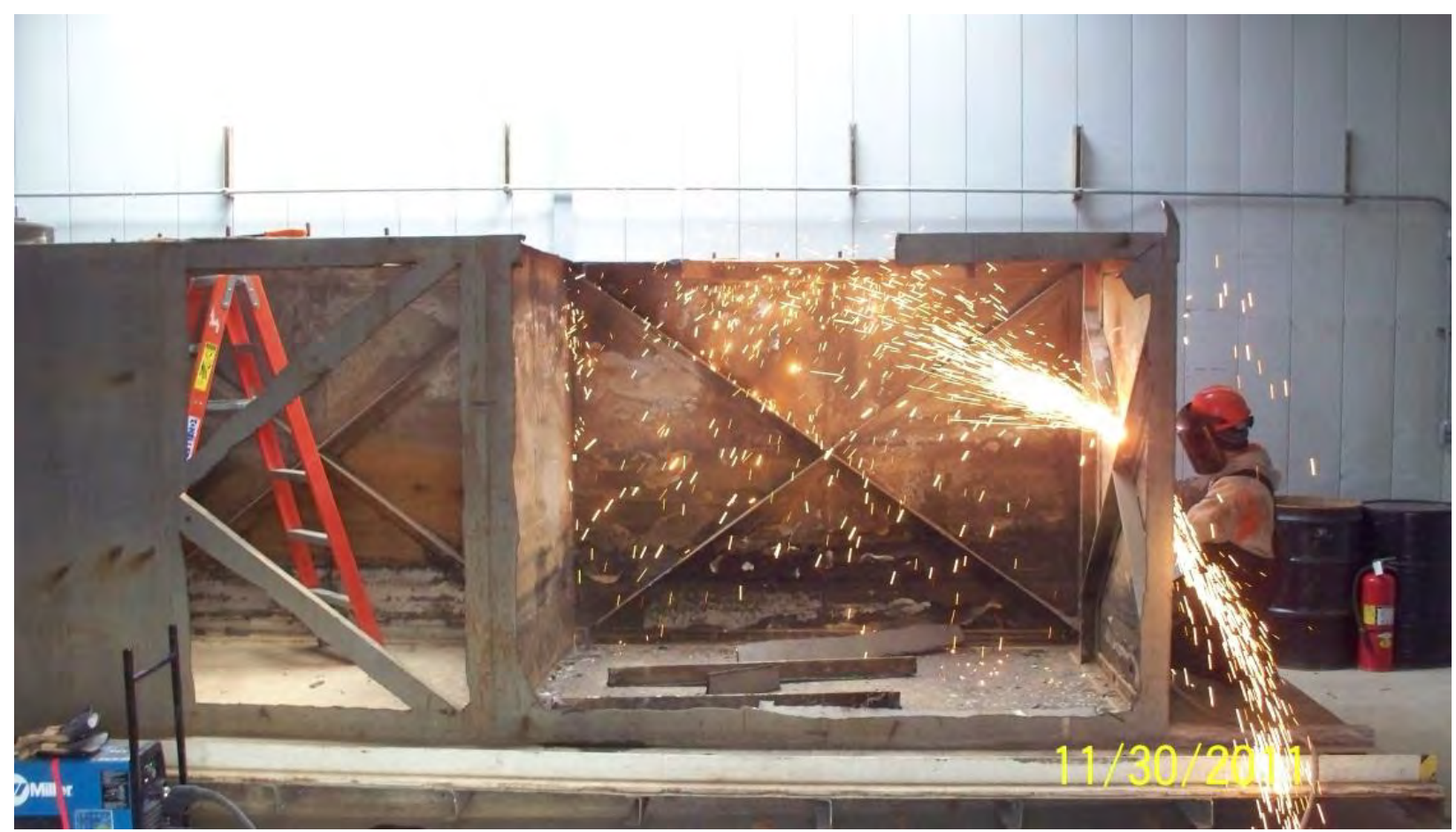

FIGURE 3.7 Dismantling of the tower support structures inside the treatment building.

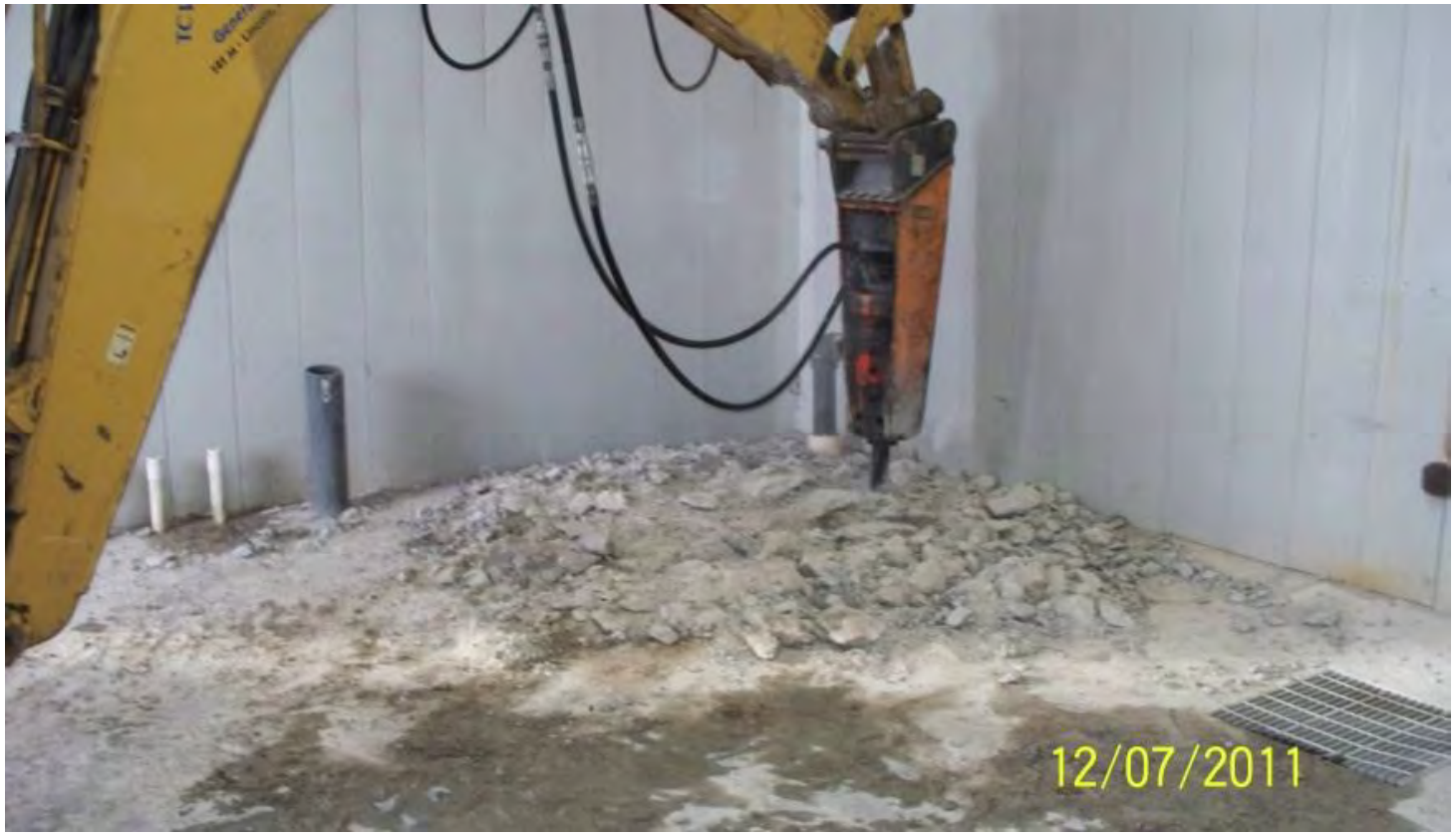

FIGURE 3.8 Removal of concrete platforms inside the treatment building. 


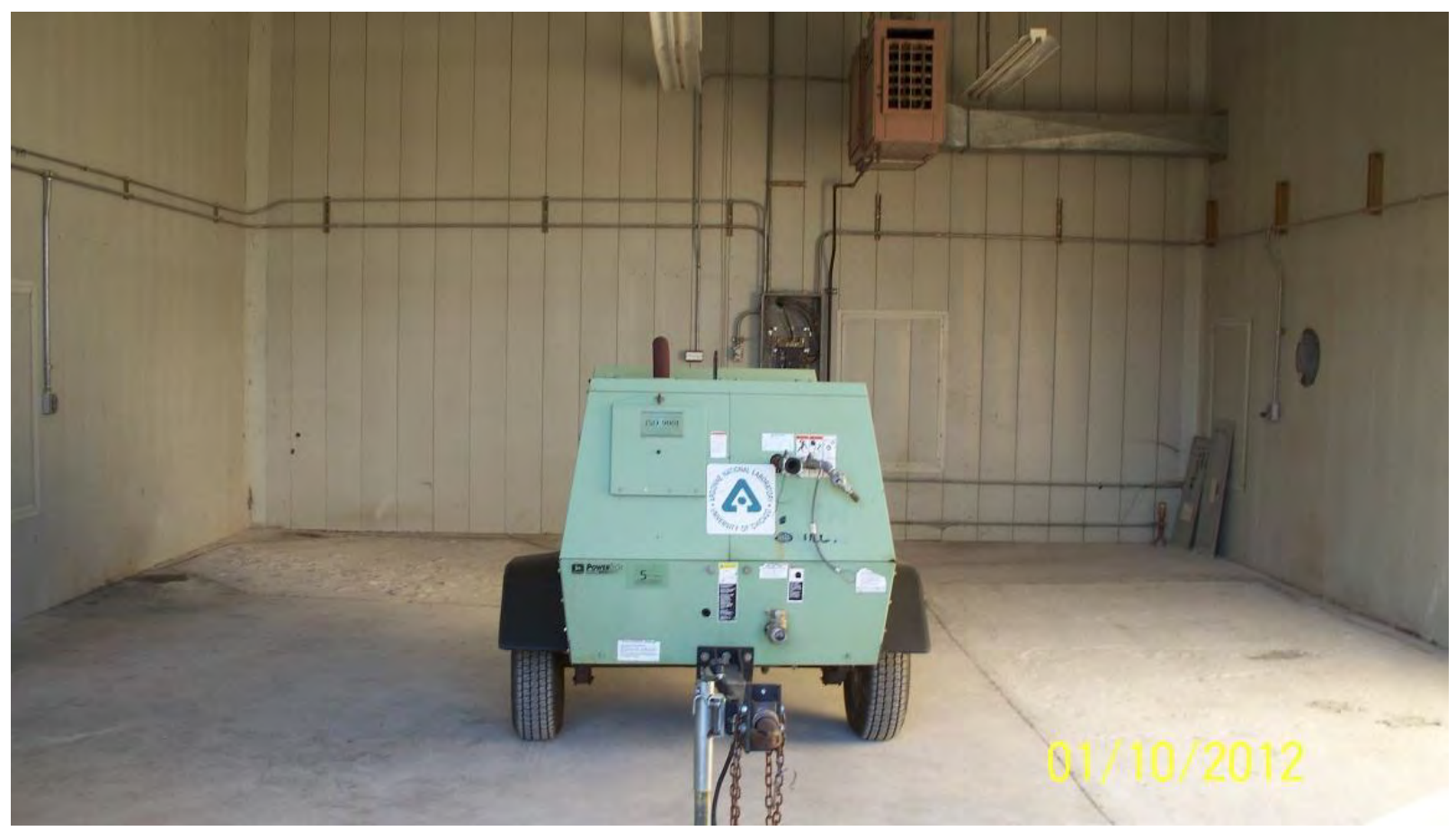

FIGURE 3.9 Interior of the treatment building after removal of all equipment.

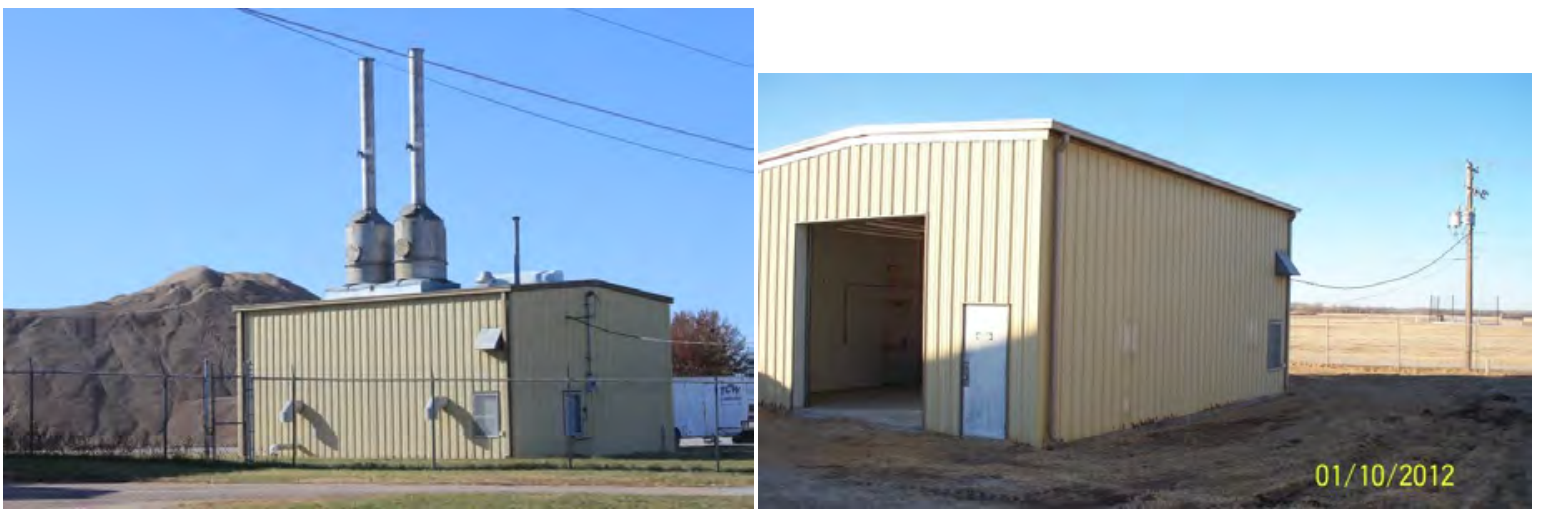

FIGURE 3.10 Treatment building before (left) and after (right) decommissioning. 


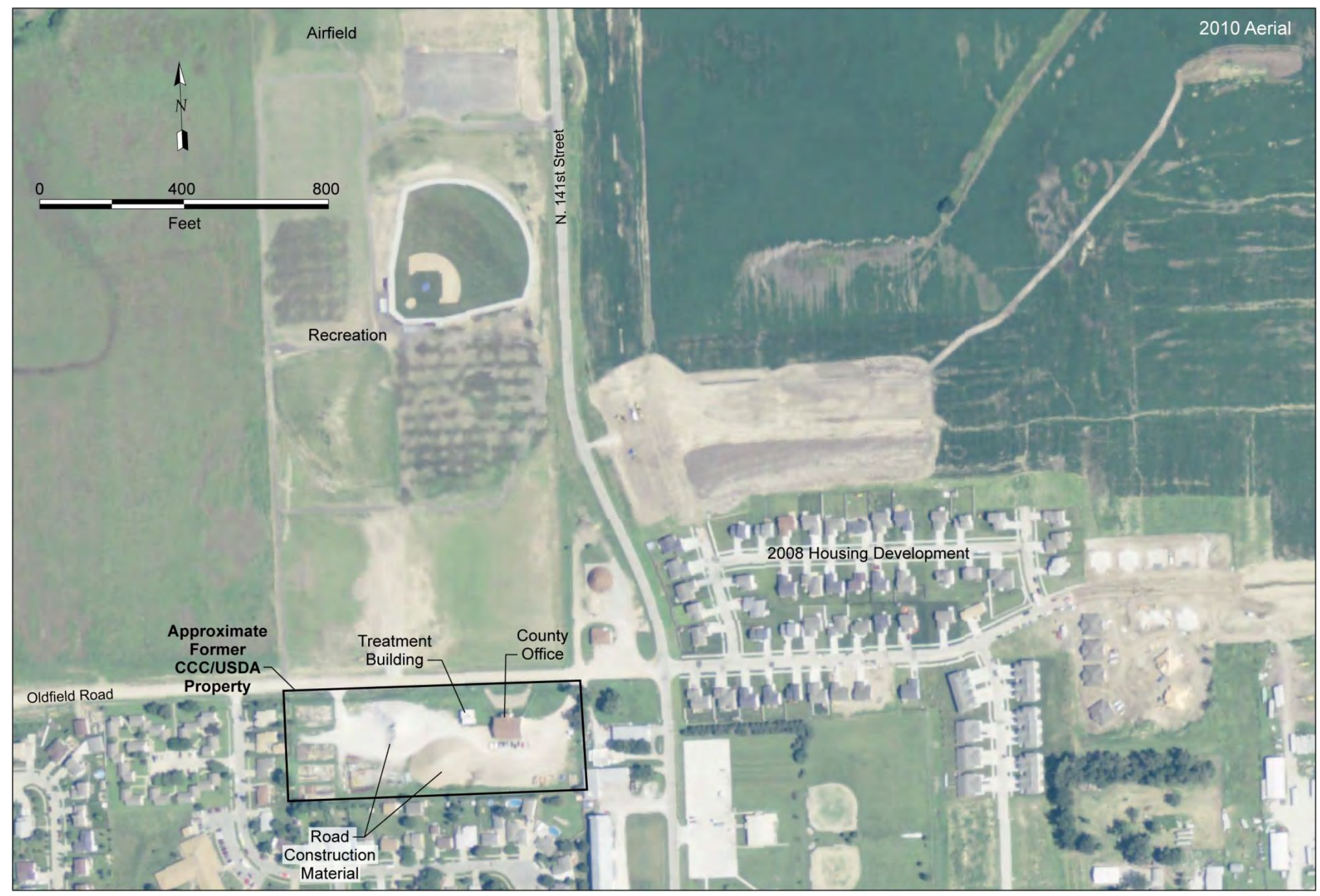

FIGURE 3.11 Contaminated area after redevelopment. Land north of Oldfield Road has been redeveloped for housing and recreation, including athletic fields and an airport for radio-controlled hobby aircraft. Source of aerial photograph: FSA (2010). 


\section{Bibliography}

Argonne, 1991, Final Work Plan: Expedited Removal Action, Waverly Contaminated Groundwater Site, Waverly, Nebraska, prepared for the Commodity Credit Corporation, U.S. Department of Agriculture by Argonne National Laboratory, Argonne, August.

Argonne, 1992a, Final Record of Decision Site Characterization Report, Waverly, Nebraska, prepared for the Commodity Credit Corporation, U.S. Department of Agriculture by Argonne National Laboratory, Argonne, Illinois, June.

Argonne, 1992b, Supplement to Final Record of Decision Site Characterization Report, Waverly, Nebraska, prepared for the Commodity Credit Corporation, U.S. Department of Agriculture by Argonne National Laboratory, Argonne, Illinois, July.

Argonne, 1993, Final Design Report for Modifications to the Waverly Groundwater Treatment System, Waverly, Nebraska, prepared for the Commodity Credit Corporation, U.S. Department of Agriculture, by Argonne National Laboratory, Argonne, Illinois, July.

Argonne, 1995, Draft Remedial Action Report: Waverly Contaminated Groundwater Site, Waverly, Nebraska, prepared for the Commodity Credit Corporation, U.S. Department of Agriculture, by Argonne National Laboratory, Argonne, Illinois, May.

Argonne, 1999, Second Performance Evaluation of the Waverly Remediation Systems, Waverly, Nebraska, Expedited Response Action, prepared for the Commodity Credit Corporation, U.S. Department of Agriculture, by Argonne National Laboratory, Argonne, Illinois, May.

Argonne, 2003, Final Work Plan for Targeted Groundwater Sampling on the Hedrick Property at Waverly, Nebraska, ANL/ER/TR-03/005, prepared for the Commodity Credit Corporation, U.S. Department of Agriculture, by Argonne National Laboratory, Argonne, Illinois, November.

Argonne, 2004a, Final Report: Targeted Groundwater Sampling on the Hedrick Property at Waverly, Nebraska, ANL/ER/TR-04/005, prepared for the Commodity Credit Corporation, U.S. Department of Agriculture, by Argonne National Laboratory, Argonne, Illinois, November. 
Argonne, 2004b, Draft Recommendations for Additional Groundwater Monitoring Wells at Waverly, Nebraska, ANL/ER/TR-04/009, prepared for the Commodity Credit Corporation, U.S. Department of Agriculture, by Argonne National Laboratory, Argonne, Illinois, November.

EPA, 1990, Superfund Record of Decision: Waverly Ground Water Contamination, Nebraska, EPA/ROD/R07-90/039, Office of Emergency and Remedial Response, U.S. Environmental Protection Agency, Washington, D.C., September.

EPA, 1993, Five-Year Review, Level One, Waverly Ground Water Contamination, Waverly, Nebraska, U.S. Environmental Protection Agency, Region VII, Kansas City, Kansas, September 27.

EPA, 1999, Five-Year Review, Level One, Waverly Ground Water Contamination, Waverly, Nebraska, U.S. Environmental Protection Agency, Region VII, Kansas City, Kansas, September 30.

EPA, 2002, OSWER Draft Guidance for Evaluation the Vapor Intrusion to Indoor Air Pathways from Groundwater and Soil (Subsurface Vapor Intrusion Guidance), U.S. Environmental Protection Agency, September 19 (http://www.epa.gov/epaoswer/hazwaste/ca/eis/vapor.htm).

EPA, 2004, Third Five-Year Review Report for Waverly Groundwater Contamination Site, Lancaster County, Waverly, Nebraska, U.S. Environmental Protection Agency, Region VII, Kansas City, Kansas, September 28.

EPA, 2005, EPA Superfund Explanation of Significant Differences: Waverly Ground Water Contamination, EPA ID NED980862718, OU 01, Waverly, Nebraska, EPA/ESD/R07-05/041, U.S. Environmental Protection Agency, Washington, D.C., March 10.

EPA, 2006a, Final Remedial Action Report, Waverly Groundwater Contamination Site, Waverly, Nebraska, U.S. Environmental Protection Agency, Region VII, Kansas City, Kansas, June 28.

EPA, 2006b, Final Close-Out Report, Waverly Groundwater Contamination Site, Waverly, Nebraska, U.S. Environmental Protection Agency, Region VII, Kansas City, Kansas, August 2. 
EPA, 2009, Fourth Five-Year Review Report for Waverly Groundwater Contamination Site, Lancaster County, Waverly, Nebraska, U.S. Environmental Protection Agency, Region VII, Kansas City, Kansas, August 13.

FSA, 2010, FSA SID - State Plane (color digital image for Waverly, Nebraska, based on JulyAugust aerial photography with 1-m resolution, rectified by using existing Digital Orthophoto Quadrangles), Farm Service Agency, U.S. Department of Agriculture, Washington, D.C.

Gilmore, S., 2004, personal communication from Steve Gilmore (Commodity Credit Corporation, U.S. Department of Agriculture, Washington, D.C.) to L.M. LaFreniere (Argonne National Laboratory, Argonne, Illinois), September 1.

Woodward-Clyde, 1986, Engineering Evaluation and Cost Analyses (EECA), Waverly, Nebraska, prepared by Woodward-Clyde Consultants, Overland Park, Kansas, for the U.S. Environmental Protection Agency, Washington, D.C., May.

Woodward-Clyde, 1988a, Site Characterization Report and Description of Expedited Response Action System, Waverly Groundwater Contamination Site, Waverly, Nebraska, prepared by Woodward-Clyde Consultants, Overland Park, Kansas, for the U.S. Environmental Protection Agency, Washington, D.C., February.

Woodward-Clyde, 1988b, Treatment Plant Facility Operations and Maintenance Manual for the Expedited Response Action Systems, Waverly Groundwater Contamination Site, Waverly, Nebraska, prepared by Woodward-Clyde Consultants, Overland Park, Kansas, for the U.S. Environmental Protection Agency, Washington, D.C., February. 


\section{Appendix A:}

U.S. Environmental Protection Agency Summary, Waverly Ground Water Contamination Site, Nebraska, EPA ID\# NED980862718 
WAVERLY GROUND WATER

CONTAMINATION

NEBRASKA

\section{EPA ID\# NED980862718}

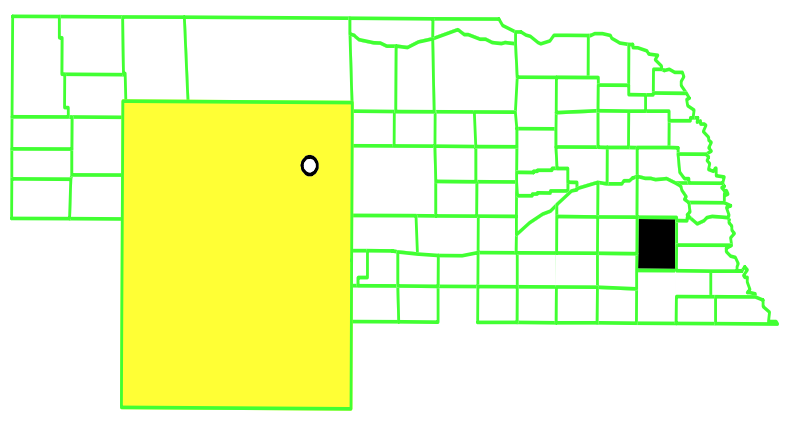

EPA Region 7

City: Waverly

County: Lancaster County

Other Names:

\section{SITE DESCRIPTION}

The Waverly Ground Water Contamination site extends over an 11-acre area underlying the City of Waverly. The U.S. Department of Agriculture operated a Federal grain facility in Waverly from 1952 to 1974. A grain fumigant consisting of carbon tetrachloride and carbon disulfide was used at the facility from 1955 to 1965. Since 1975, the property has been owned by Lancaster County, which operates a district office and maintenance facility on the premises. The EPA and the State of Nebraska sampled the municipal wells in 1982 and found them to be contaminated. One well was taken out of service, two wells were placed on standby status, and the city drilled new wells to replace them. The area surrounding the site is predominantly agricultural. The population of Waverly is approximately 1,700 people. There is a residential area adjacent to the former grain facility. Several private wells near the site are used for drinking water, livestock watering and crop irrigation. Runoff from the site drains into Salt Creek.

\section{Site Responsibility:}

This site is being addressed through Federal actions.

\section{NPL LISTING HISTORY}

Proposed Date: $\quad$ 10/15/84

Final Date:

Deleted Date: $\quad$ 11/20/2006 


\section{THREATS AND CONTAMINANTS}

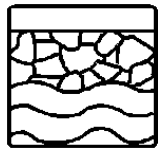

Samples taken from the municipal wells contained concentrations of heavy metals, volatile organic compounds (VOCs), nitrates, and sulfates. The soil is contaminated with VOCs including carbon tetrachloride and chloroform. Contaminants from the soil have seeped into the aquifer, the source of water for the municipal water supply. The polluted wells were taken out of service, and new wells were drilled; therefore, the municipal water supply is safe to use. The new wells are upgradient of the site and are not likely to be threatened.

\section{CLEANUP APPROACH}

\section{Response Action Status}

Immediate Actions: In 1988, as an immediate response to the ground water contamination, the EPA installed ground water monitoring wells, a system of pipes and wells in the ground connected to a pump to remove vapors contaminating soil (soil gas extraction system), and a ground water treatment system using air stripping. The ground water treatment involves forcing a stream of air through the contaminated water to evaporate the chemicals, which then are released into the atmosphere. Air monitoring is conducted to ensure that emissions are within acceptable limits. Treated ground water is discharged to a ditch near the site. The U.S. Department of Agriculture (USDA) is performing the operation and maintenance on the ground water extraction and soil gas treatment system. A supplemental groundwater extraction well (SGWEX) was added to the system in 1993 to address contamination discovered outside the influence of the original ground water extraction well.

Entire Site: The USDA completed an investigation into the nature and extent of contamination at the site. Based on the results of this investigation, the EPA recommended that the immediate actions described above be continued until cleanup of soil and ground water is achieved. Operation and maintenance of the ground water treatment system continued through 2008.

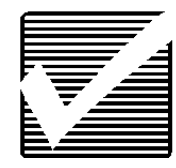

The analytical results provided in the Quarterly Report for Waverly, Nebraska, Expedited Response Action, 1st Quarter FY 2009, Reporting Period October 2008 through December 2008 indicated the contaminant levels in all sampled monitoring wells remain below the cleanup levels established in the Record of Decision. 
Site Facts: Ground water monitoring has continued on a quarterly basis since 11/20/2006 to ensure the contaminant levels remain below cleanup levels. The data gathered from these sampling activities were used in the fourth and final Five-Year Review. The fourth and final Five- Year Review was completed on August 8, 2009. The conclusion of the Five-Year Review indicated that the completed remedial action remain protective of human health and the environment and allows for unrestricted reuse of the site.

\section{ENVIRONMENTAL PROGRESS}

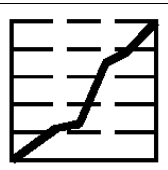
have been achieved. Therefore, the EPA has deleted this site from the NPL.

\section{COMMUNITY INVOLVEMENT}

4/2004 Fact Sheet announcing the start of the third Five-Year Review was mailed to addressees on the mailing list.

4/22/2004 Display ad announcing the start of the Five-Year Review was published in the Waverly-News .

11/2004 Fact Sheet announcing the completion of the third Five-Year Review and availability of the report was mailed to the mailing list.

11/25/2004 Display ad announcing the completion of the third Five-Year Review was published in the Waverly-News.

9/2006 Fact Sheet announcing the Proposed Deletion from the National Priorities List and the start of the Public Comment Period on the proposed delisting was mailed to the mailing list. 
9/21/2006 Display ad announcing the proposed deletion of the Waverly Site was published in the Waverly-News .

11/20/2006 Notice of Deletion appeared in the Federal Register .

12/2006 Documents relating to the deletion were added to the Site Repositories.

02/12/2009 Display ad announcing the start of the Five-Year Review was published in the Waverly News .

02/2009 Fact Sheet announcing the start of the fourth Five-Year Review was mailed.

09/2009 Display ad announcing completion of the Five-Year Review published in the Waverly News.

Congressional Districts:

U.S. Senator Ben Nelson

U.S. Senator Mike Johanns

U.S. Senator Kathy Campbell District 25

U.S. Representative Jeff Fortenberry 


\section{SITE REPOSITORY}

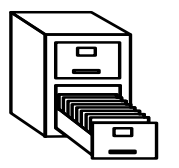

Contact the Region 7 Superfund
Community Relations Office
Superfund Records Center

901 N. 5th St.

Kansas City, KS 66101

Mail Stop SUPR

(913)551-7166

\section{REGIONAL CONTACTS}

SITE MANAGER:

E-MAIL ADDRESS:

PHONE NUMBER:

COMMUNITY INVOLVEMENT

COORDINATOR:

PHONE NUMBER:

E-MAIL ADDRESS:

STATE CONTACT:

PHONE NUMBER:
Jeff Field/SUPR/MOKS

field.jeff@epa.gov

(913) 551-7548

Dianna Whitaker

913-551-7598

whitaker.dianna@epa.gov

Mike Felix, NDEQ

402-471-2938

\section{MISCELLANEOUS INFORMATION}

STATE:

CONGRESSIONAL DISTRICT:

EPA ORGANIZATION:
NE

071X

01

SFD-SUPR/MOKS

\section{MODIFICATIONS}

$\begin{array}{llll}\text { Created by: } & \text { Karla } & \text { Created Date: } & \text { 10/17/97 02:26 PM } \\ & \text { Asberry/SUPRFUND/R7/US } & \\ & \text { EPA/US } & & \\ \text { Last Modified by: } & \text { Ben } & \text { Last Modified Date: } & \text { 10/11/2011 04:39 PM } \\ & \text { Washburn/R7/USEPA/US } & & \end{array}$




\section{Appendix B:}

Photographs of the Decommissioning Effort 


\section{Groundwater Monitoring Well Locations}

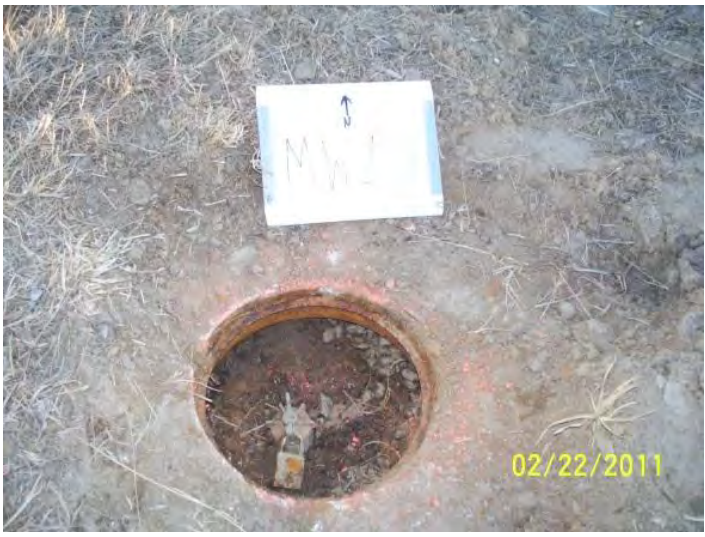

MW1A

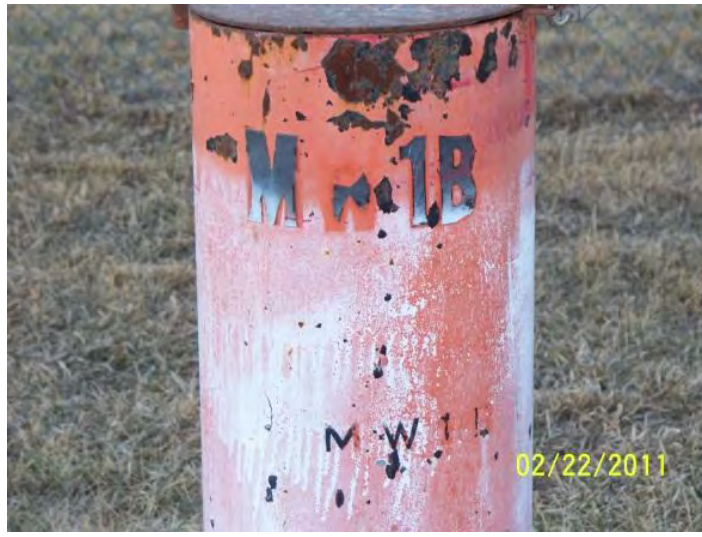

MW1B

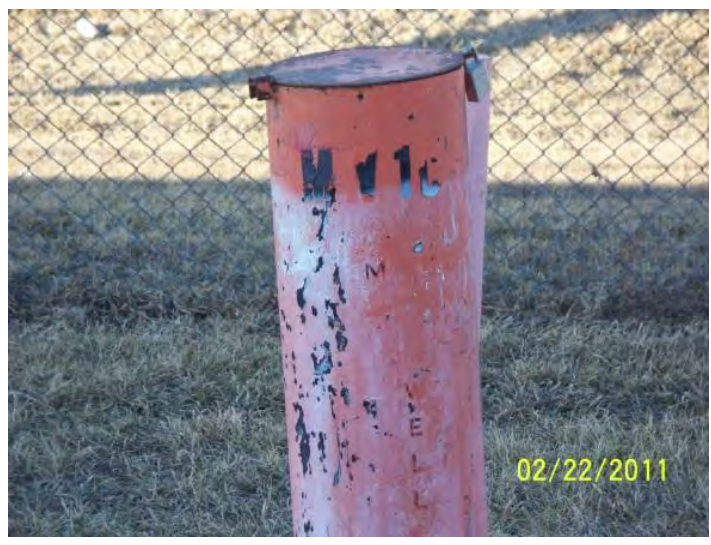

MW1C

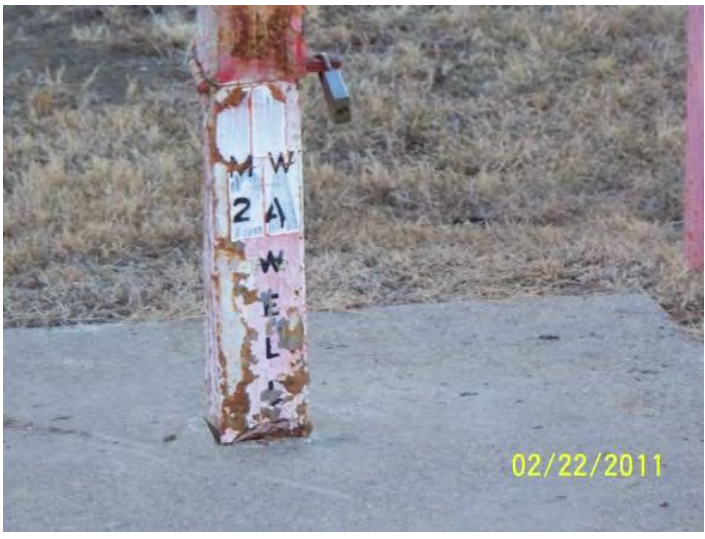

MW2A

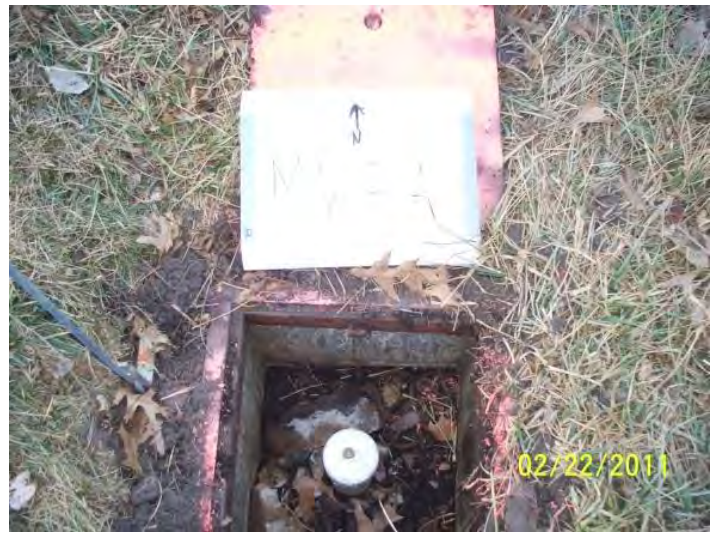

MW2A 


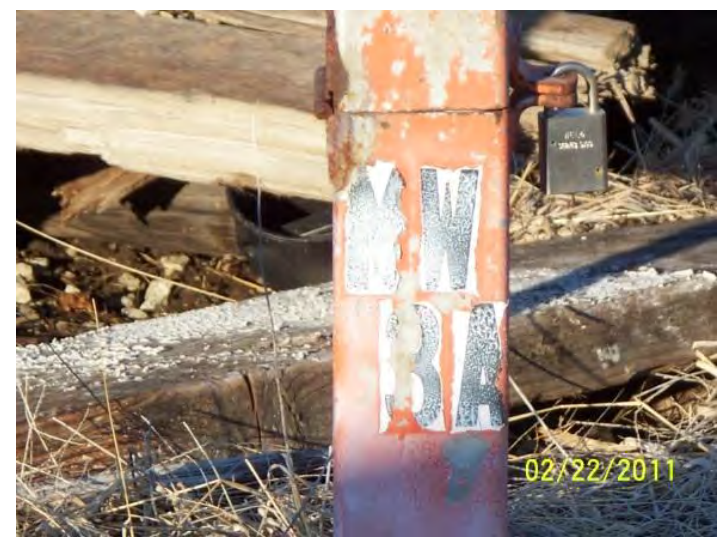

MW3A

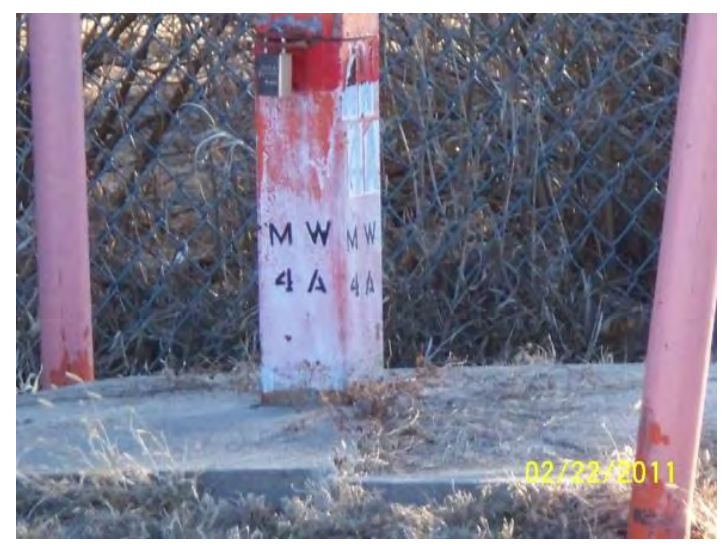

MW4A
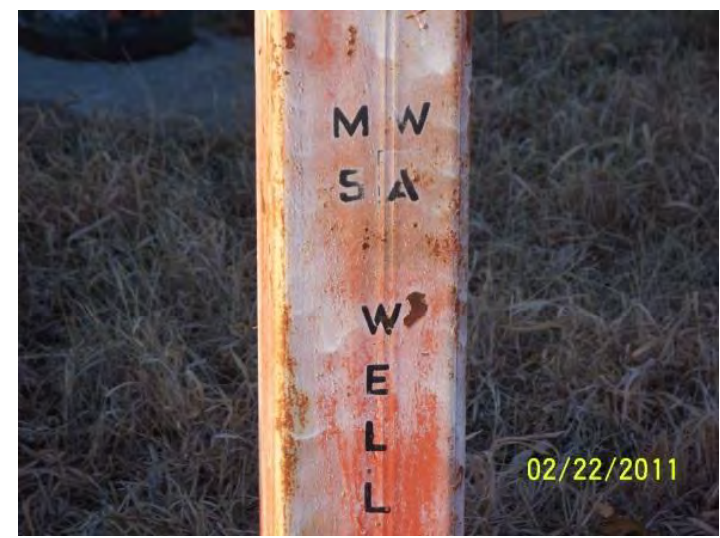

MW5A

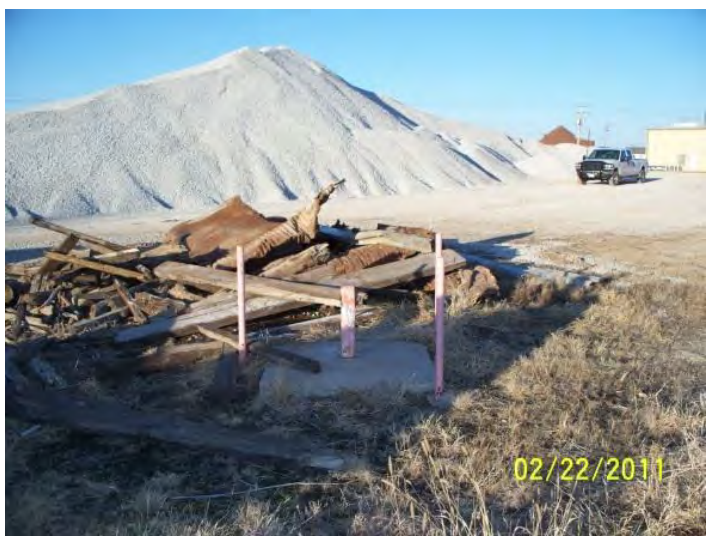

MW3A
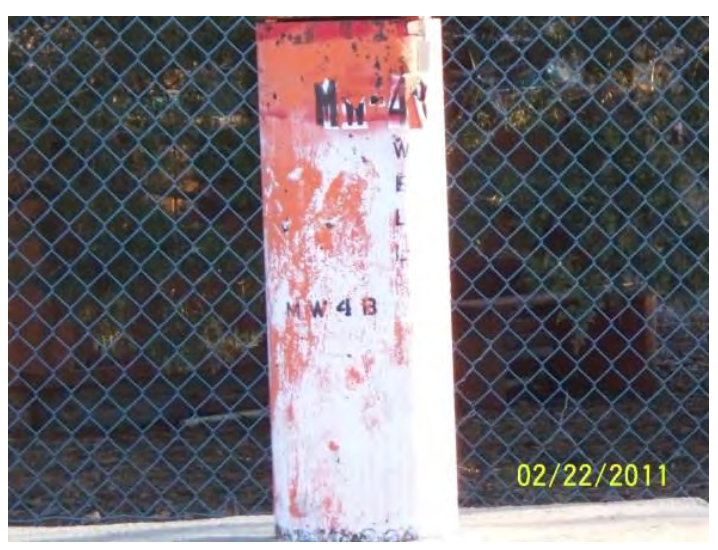

MW4B

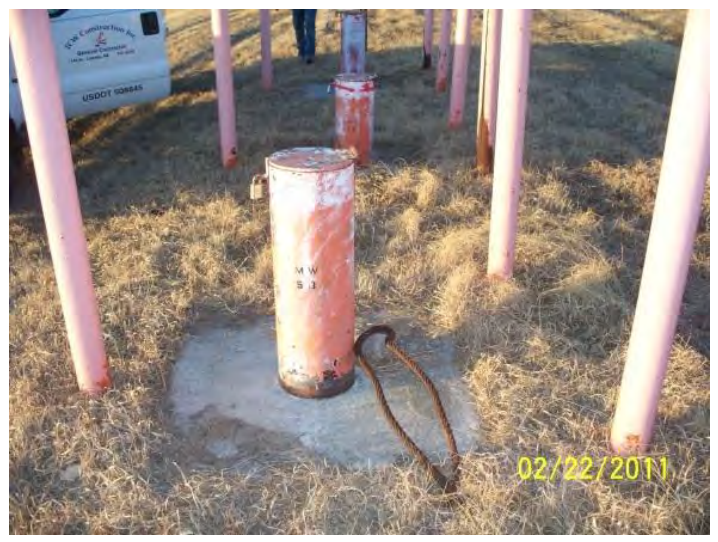

MW5B 


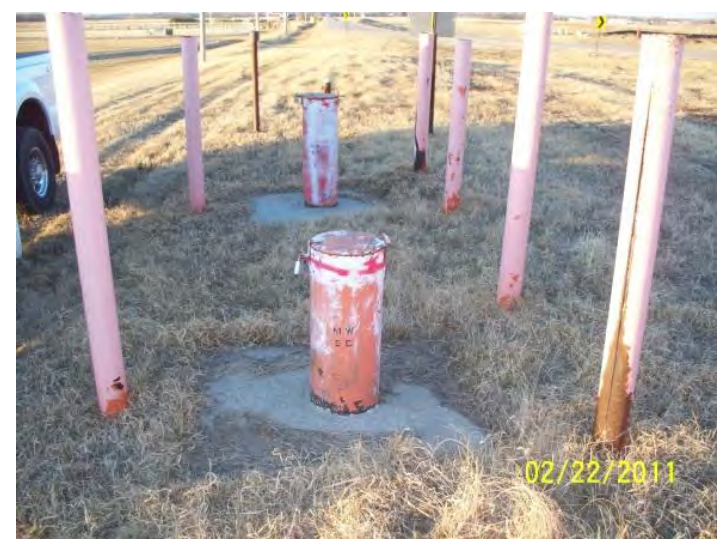

MW5C

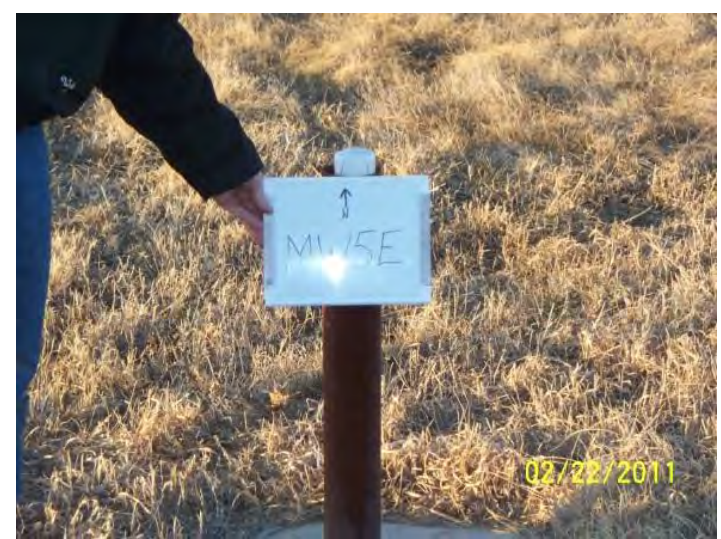

MW5E

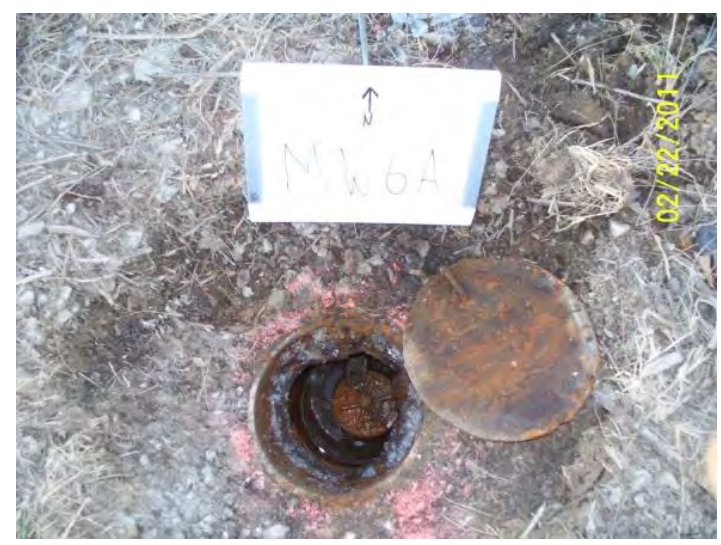

MW6A

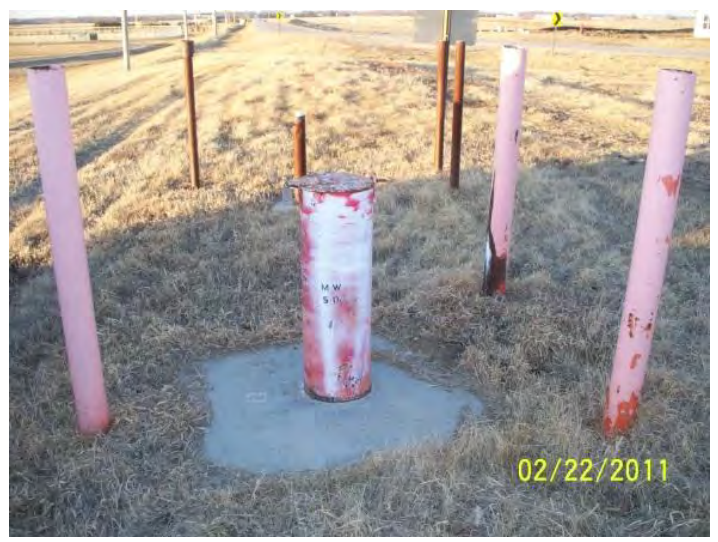

MW5D

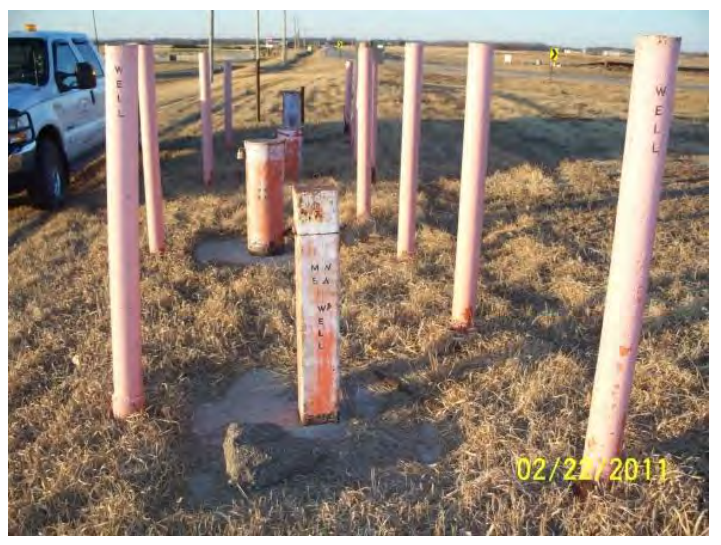

MW5A, B, C, D

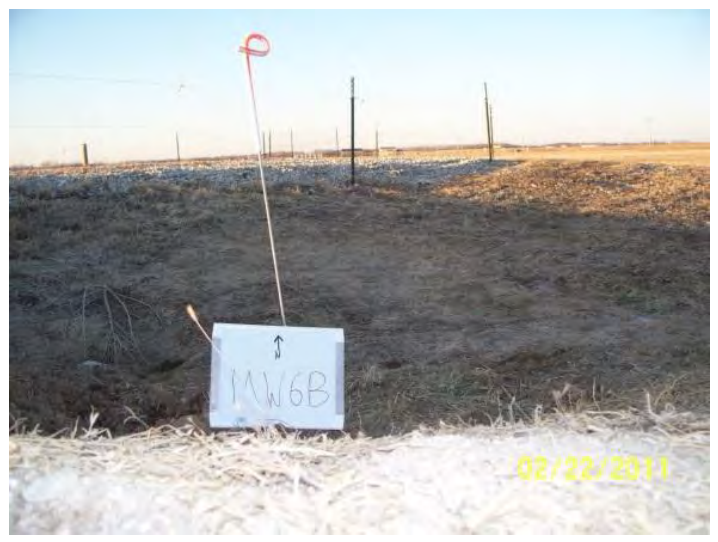

MW6B 


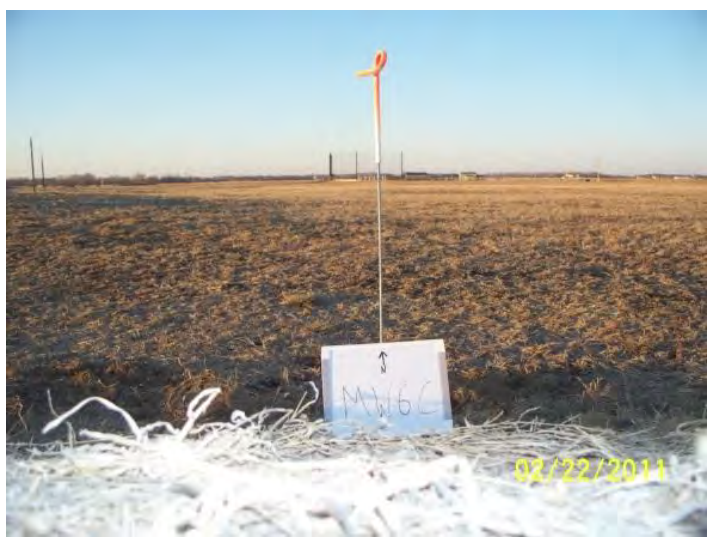

\section{MW6C}

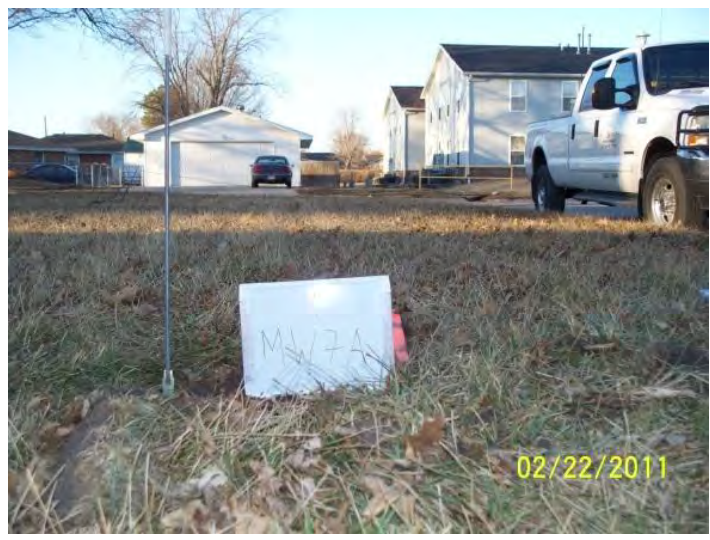

MW7

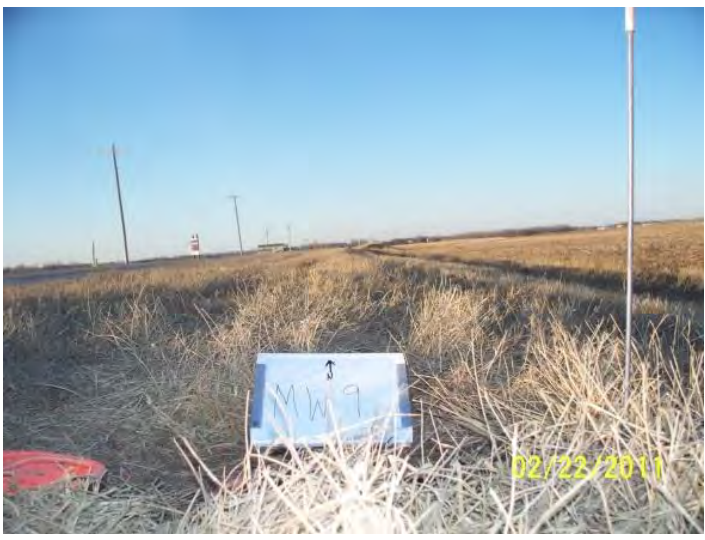

MW9

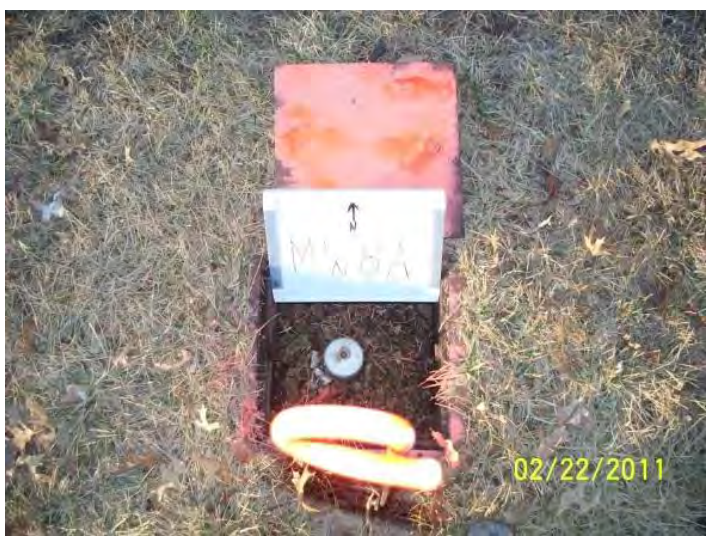

MW8

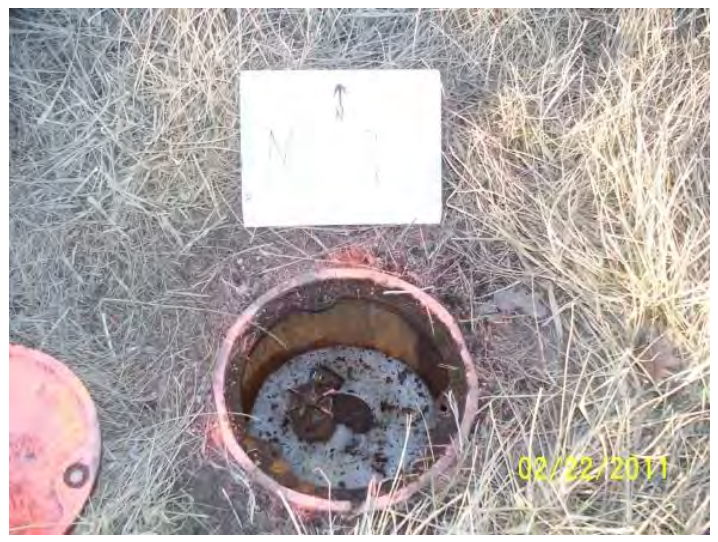

MW9 


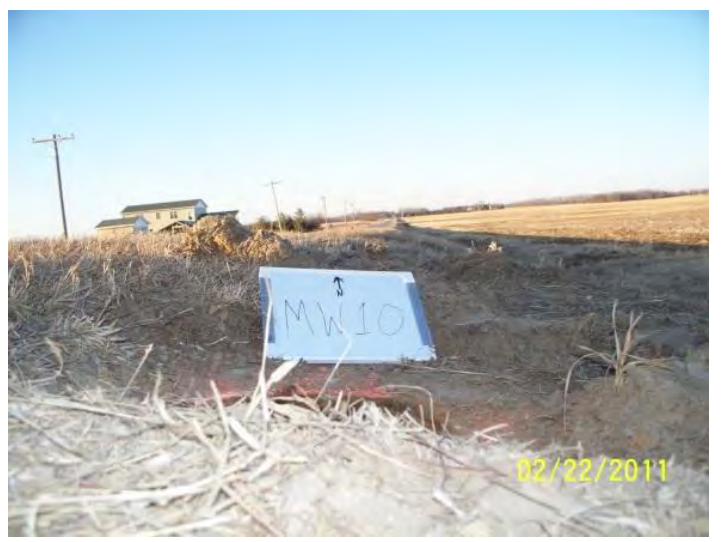

\section{MW10}

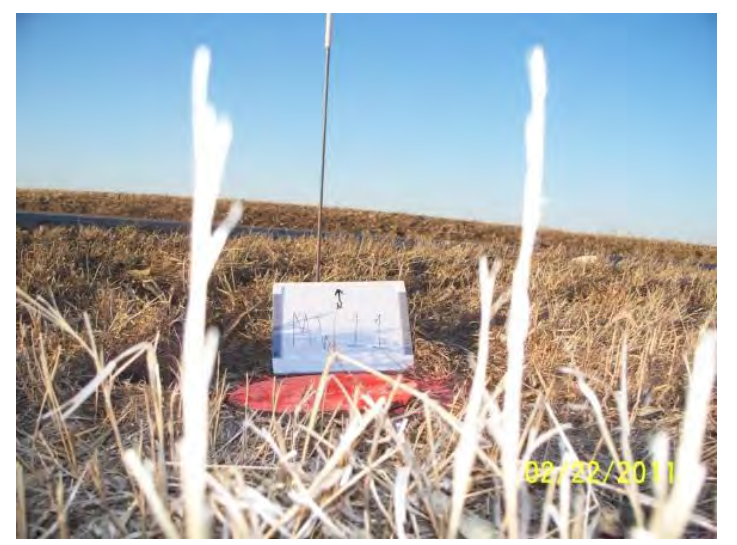

MW11

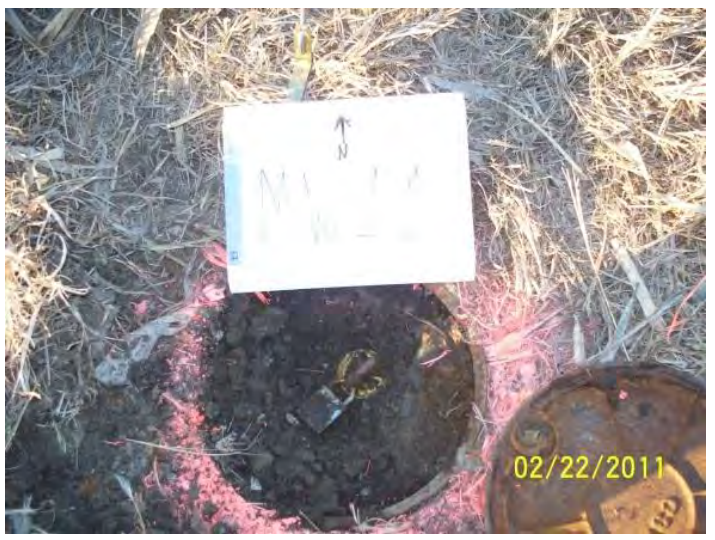

MW11

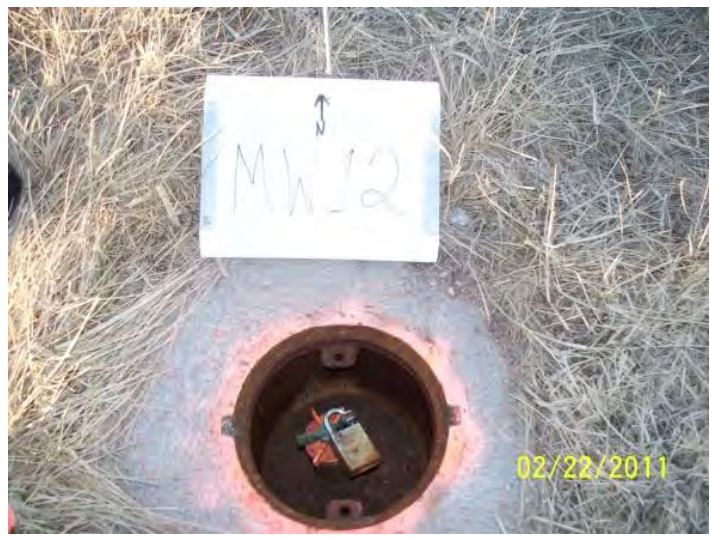

MW12 


\section{Vapor Extraction Well Locations}

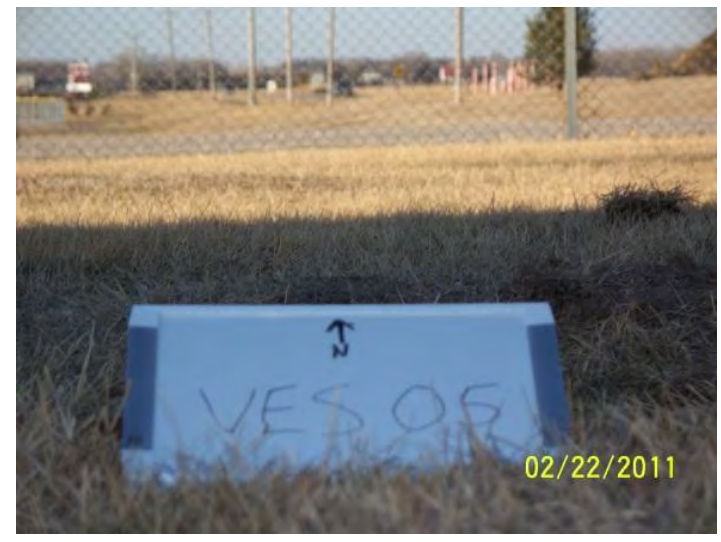

VES5

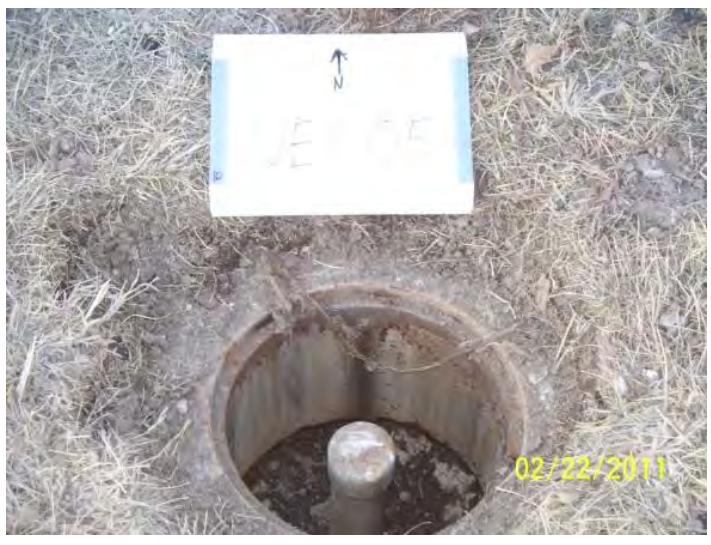

VES5

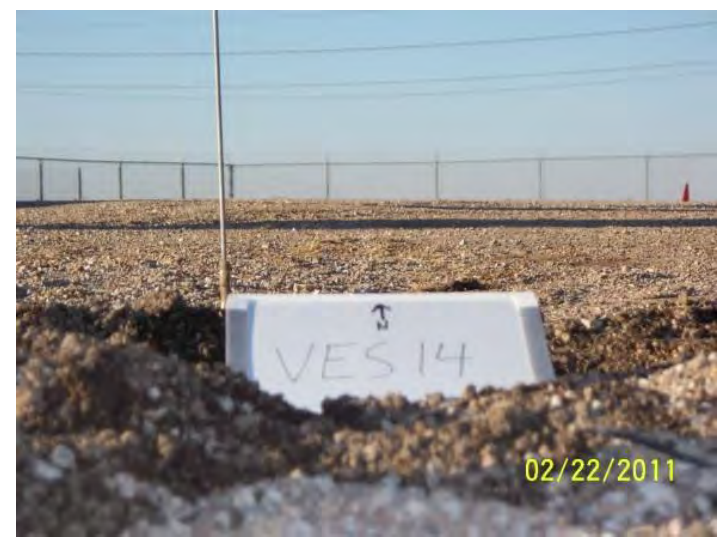

VES14

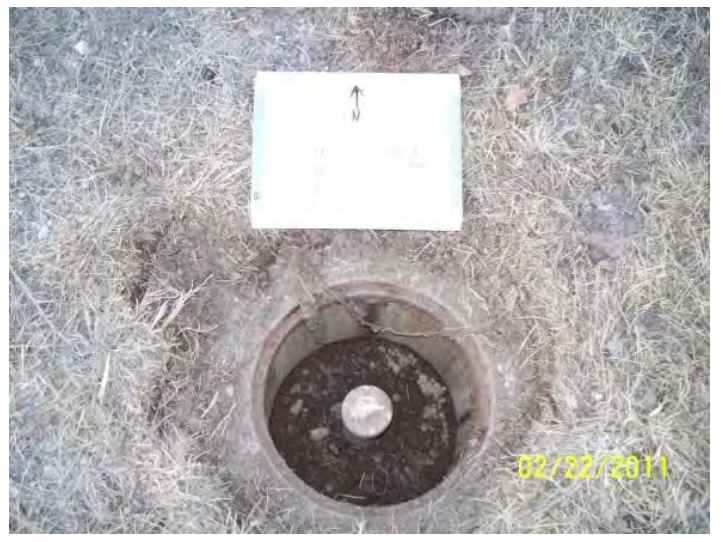

VES5

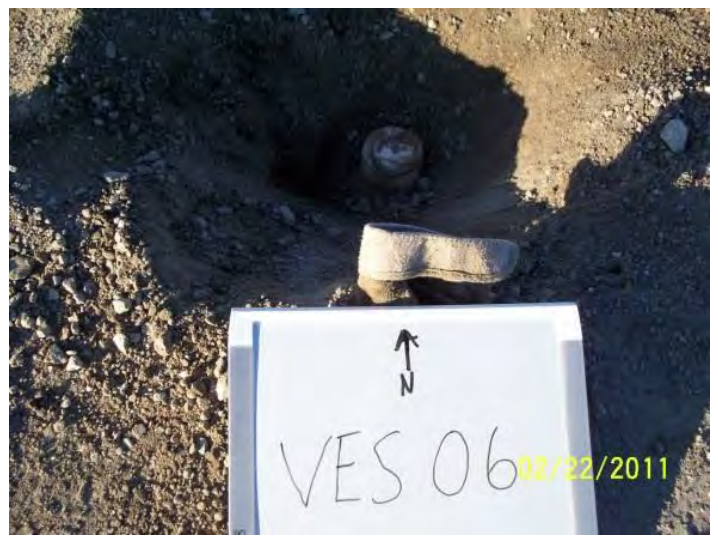

VES6

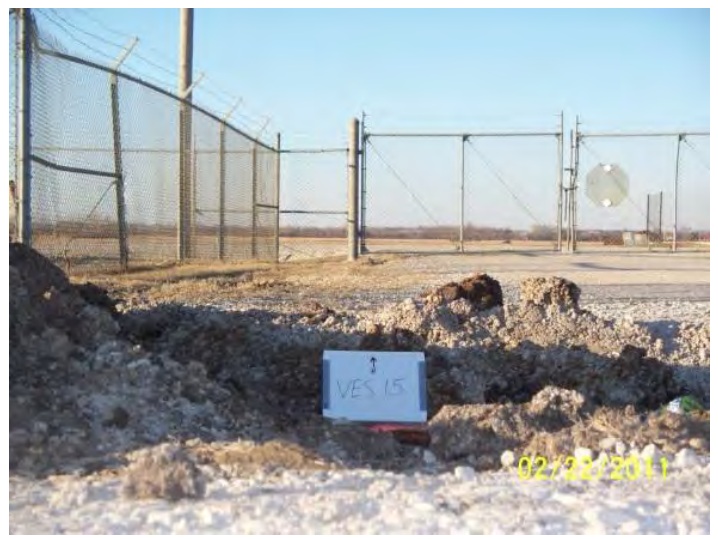

VES15 


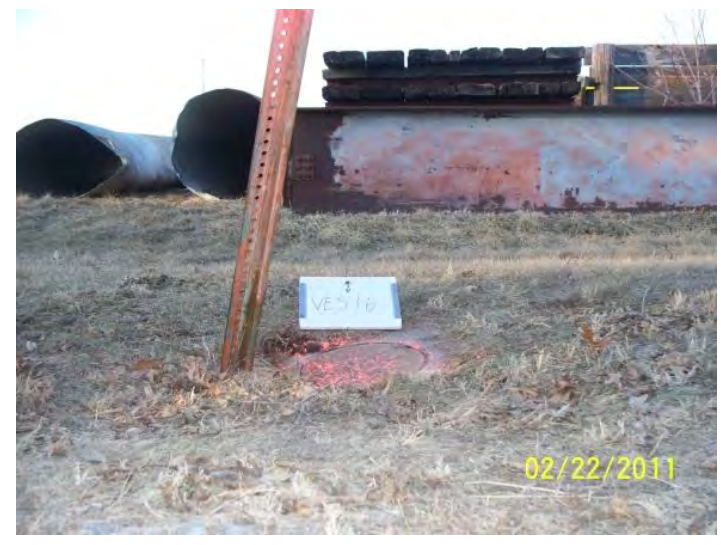

VES16

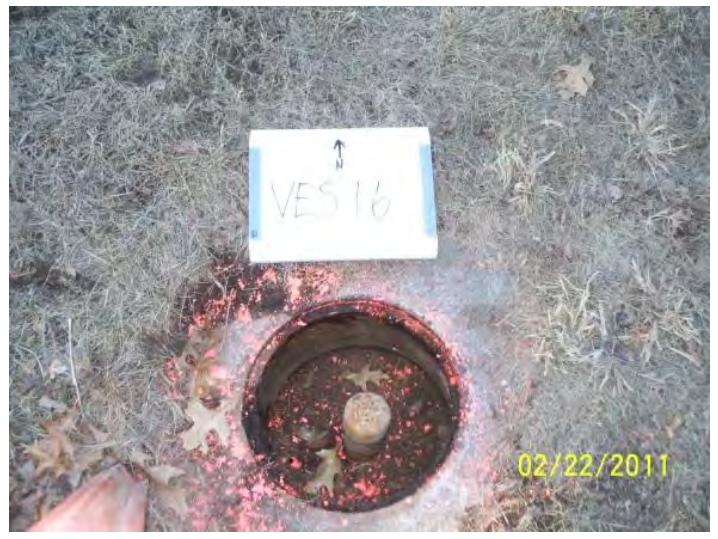

VES16

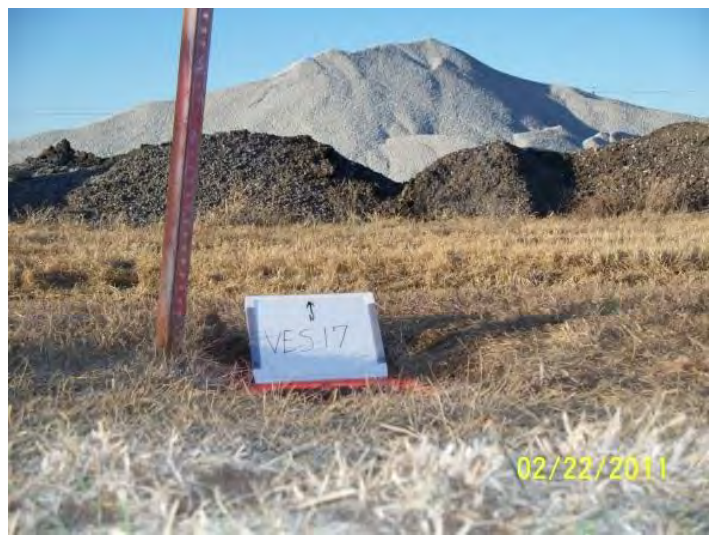

VES17 


\section{Groundwater Extraction Well Locations}

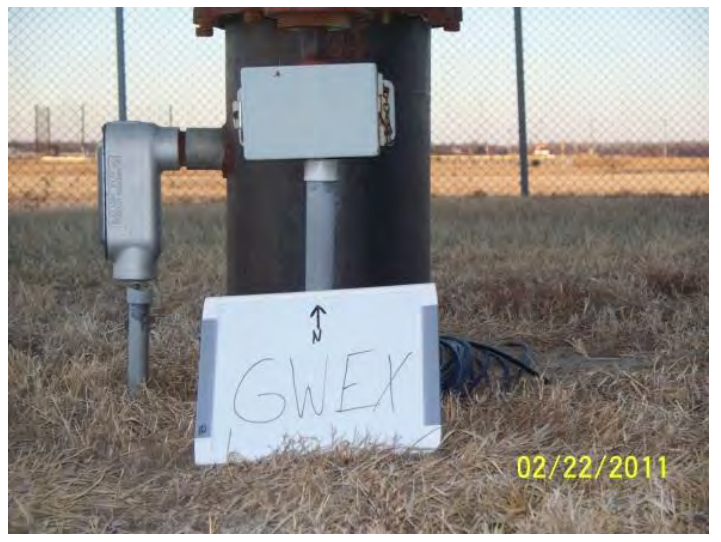

GWEX

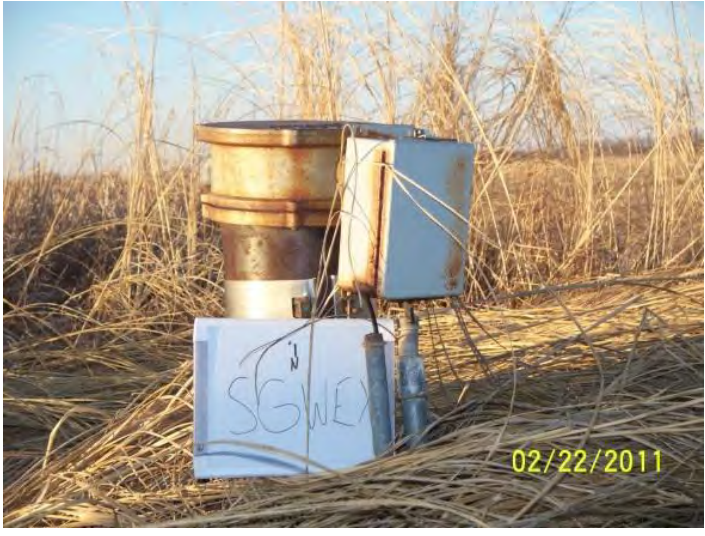

SGWEX

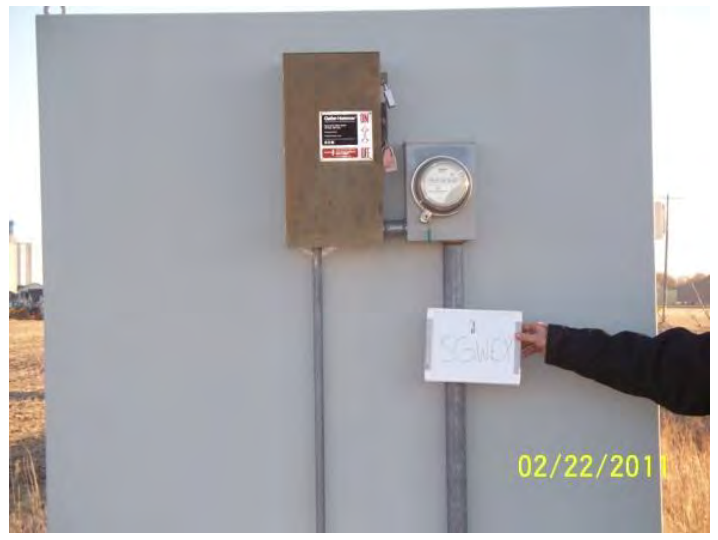

SGWEX 


\section{Soil Gas Monitoring Well Locations}

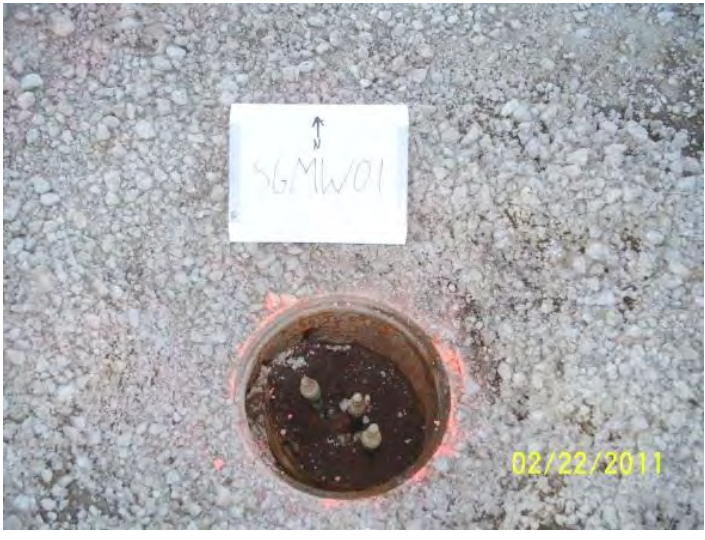

SGMW1

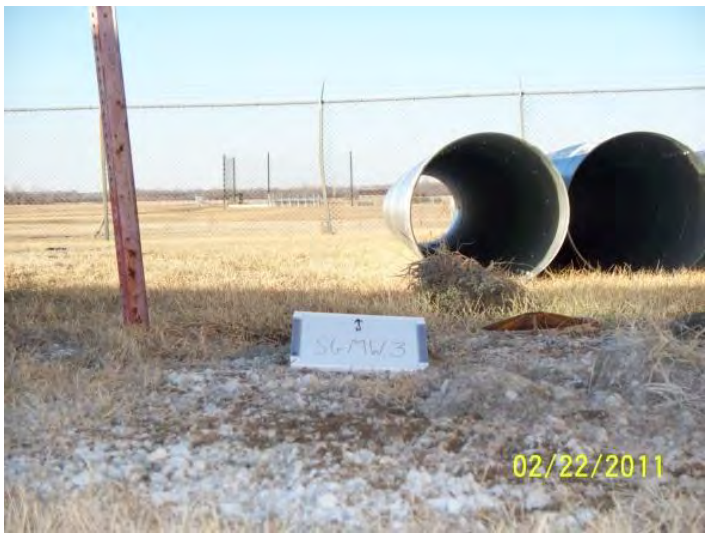

SGMW3

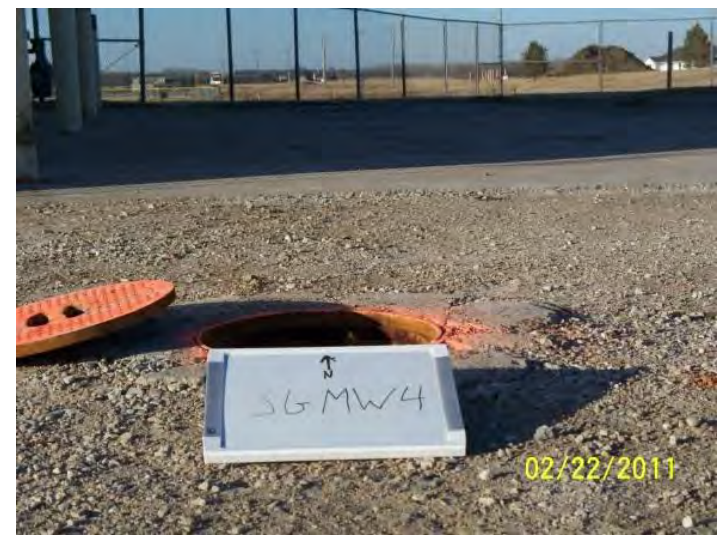

SGMW4

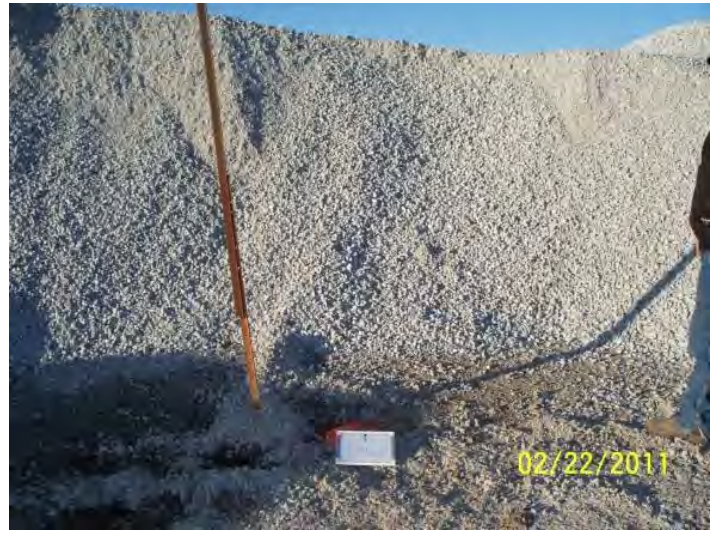

SGMW2

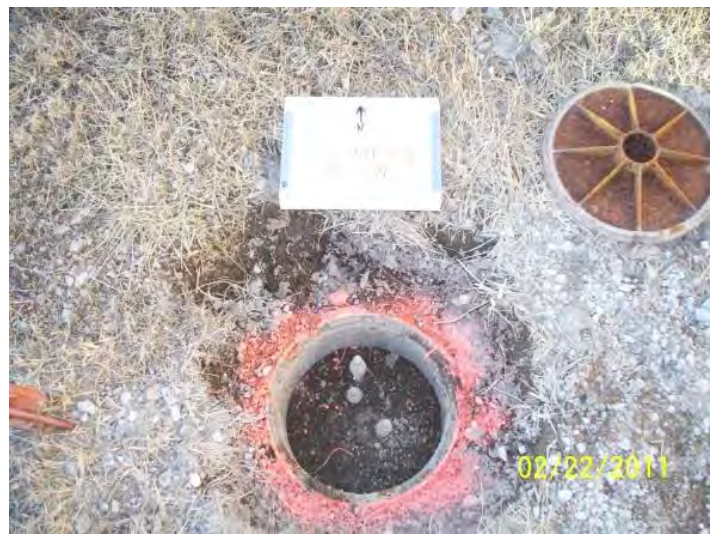

SGMW3

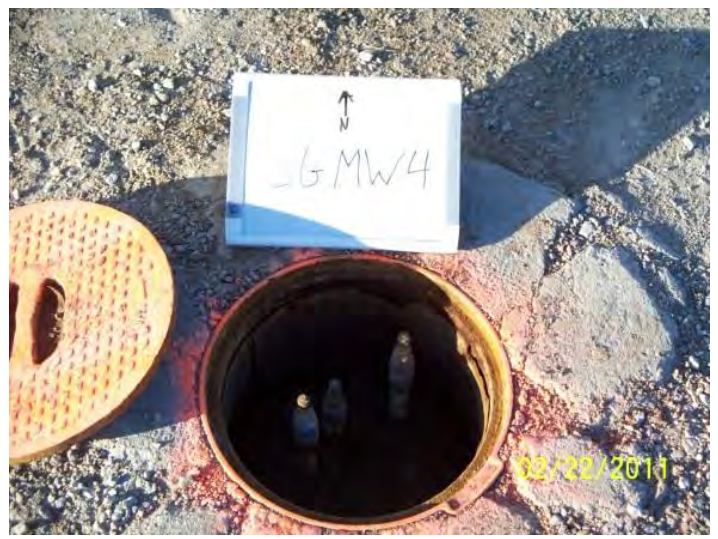

SGMW4 


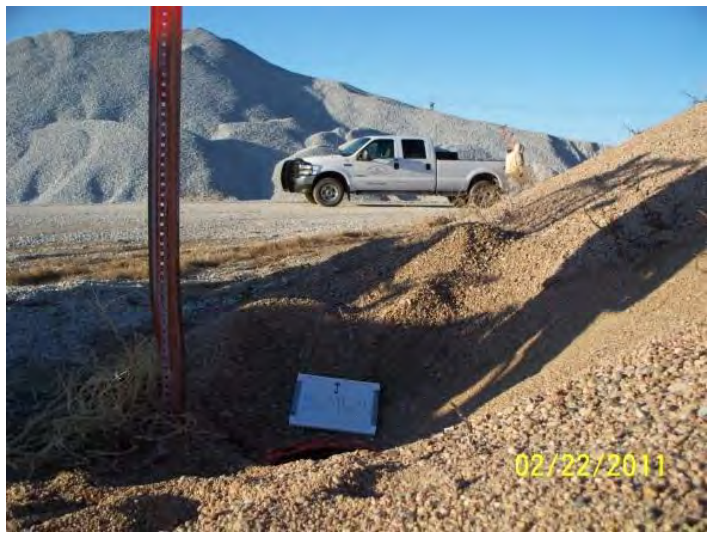

SGMW5 
SGWEX Decommissioning
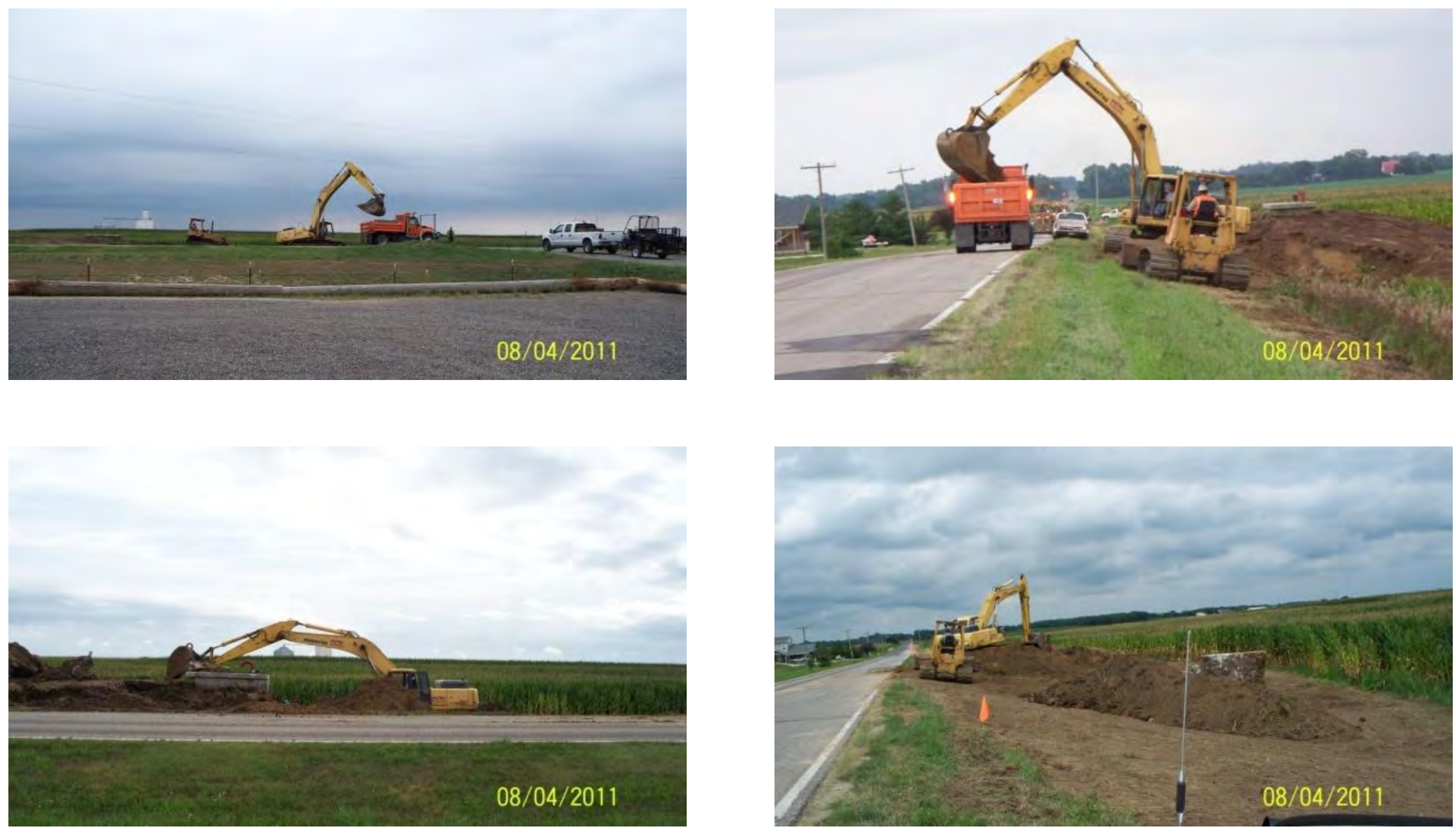

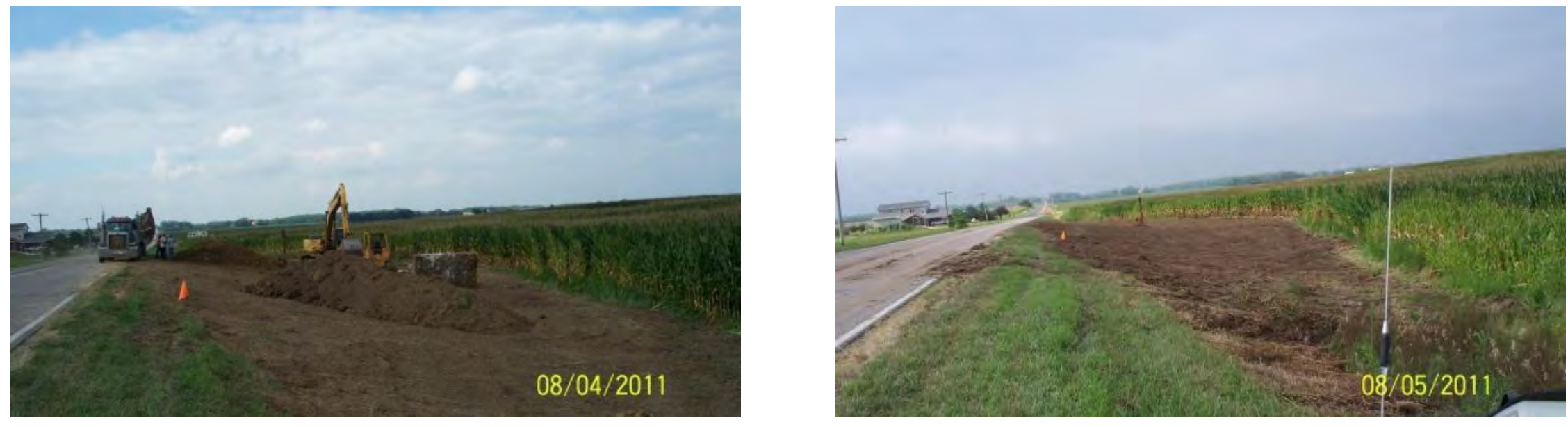

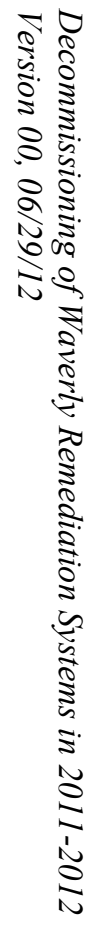

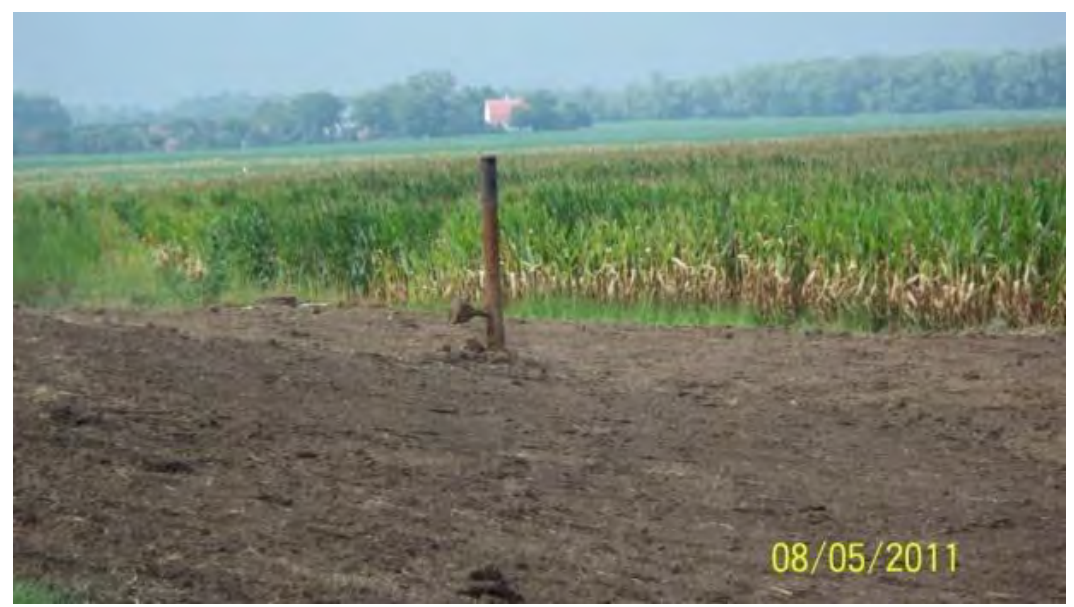




\section{Appendix C:}

\section{Notice of Water Well Decommissioning Forms}


Waverly Well Registration Numbers

Arranged by well number

(Appendix C order)

Arranged by registration number

\begin{tabular}{|c|c|}
\hline Well & Registration Number \\
\hline MW1A & 212251 \\
\hline MW1B & 212252 \\
\hline MW1C & 212253 \\
\hline MW2A & 212254 \\
\hline MW3A & 212255 \\
\hline MW4A & 212256 \\
\hline MW4B & 212257 \\
\hline MW5A & 212258 \\
\hline MW5B & 212259 \\
\hline MW5C & 212260 \\
\hline MW5D & 212261 \\
\hline MW5E & 212262 \\
\hline MW6A & 212263 \\
\hline MW6B & 212264 \\
\hline MW6C & 212265 \\
\hline MW7 & 212266 \\
\hline MW8 & 212267 \\
\hline MW9 & 212268 \\
\hline MW10 & 212269 \\
\hline MW11 & 212270 \\
\hline MW12 & 212271 \\
\hline VES1 & 212272 \\
\hline VES2 & 212273 \\
\hline VES3 & 212274 \\
\hline VES4 & 212275 \\
\hline VES5 & 212276 \\
\hline VES6 & 212277 \\
\hline VES7 & 216356 \\
\hline VES8 & 212278 \\
\hline VES9 & 212279 \\
\hline VES10 & 212280 \\
\hline VES11 & 212281 \\
\hline VES12 & 212282 \\
\hline VES13 & 212283 \\
\hline VES14 & 212284 \\
\hline VES15 & 212285 \\
\hline VES16 & 212286 \\
\hline VES17 & 212287 \\
\hline SGMW1 & 212288 \\
\hline SGMW2 & 212289 \\
\hline SGMW3 & 212290 \\
\hline SGMW4 & 212291 \\
\hline SGMW5 & 212292 \\
\hline GWEX & 212293 \\
\hline SGWEX & 212294 \\
\hline
\end{tabular}

\begin{tabular}{|l|c|}
\hline Well & Registration Number \\
\hline & \\
\hline MW1A & 212251 \\
\hline MW1B & 212252 \\
\hline MW1C & 212253 \\
\hline MW2A & 212254 \\
\hline MW3A & 212255 \\
\hline MW4A & 212256 \\
\hline MW4B & 212257 \\
\hline MW5A & 212258 \\
\hline MW5B & 212259 \\
\hline MW5C & 212260 \\
\hline MW5D & 212261 \\
\hline MW5E & 212262 \\
\hline MW6A & 212263 \\
\hline MW6B & 212264 \\
\hline MW6C & 212265 \\
\hline MW7 & 212266 \\
\hline MW8 & 212267 \\
\hline MW9 & 212268 \\
\hline MW10 & 212269 \\
\hline MW11 & 212270 \\
\hline MW12 & 212271 \\
\hline VES1 & 212272 \\
\hline VES2 & 212273 \\
\hline VES3 & 212274 \\
\hline VES4 & 212275 \\
\hline VES5 & 212276 \\
\hline VES6 & 212277 \\
\hline VES8 & 212278 \\
\hline VES9 & 212279 \\
\hline VES10 & 212280 \\
\hline VES11 & 212281 \\
\hline VES12 & 212282 \\
\hline VES13 & 212283 \\
\hline VES14 & 212284 \\
\hline VES15 & 212285 \\
\hline VES16 & 212286 \\
\hline VES17 & 212287 \\
\hline SGMW1 & 212288 \\
\hline SGMW2 & 212290 \\
\hline SGMW3 & \\
\hline SGMW4 & \\
\hline SGMW5 & 21293 \\
\hline GWEX & \\
\hline VES7 & \\
\hline
\end{tabular}




\section{NOTICE OF WATER WELL DECOMMASSIONING}

\section{FOR DEPARTMENT USE ONLY}

Date Filed_ $8 / 16 / 11$ 08162011 $-\frac{21225}{\text { Well ID }}$ Owner Code No. 60538 Registration No. - DeCf

1. Well Owner"s First Name

OR Company Name United States Dept of A Aricultur

Addiess

$$
1408
$$

Civ Nashineter

Independance Ave

\section{$0<$}

5 W Reom 4719 Zip 20250 Telephone

2. Contiactor (if applicable). Lebster Lell Serves Ihe Telephone Number(402 666-9222 Address Pro.fen 128 City Mars bluff Emais: Whsianutcenet Contractor License No. State Ne. Zip Code $68648+$ 39495
This form is required to be filed within 60 days of decommissioning of the water well.

3z. Weit Registration No.

3. Purpose of Well:

$$
\text { Monitoria }
$$

ic. Daie Well Last Operated. unk

3e. List complete well location: Legal, Footage and/or GPS foordinates

The well is

$3 / 4$ of the Sw $1 / 4$ of Section 18 , Township. feet from the (N口or $S \square$ ) section line and
OR Latitude Degree: $\quad 40$

3. Location of Water Use:
Minute: $\frac{55}{31}$ Second:/ 7.00 Second: 56.00

\footnotetext{
4. Actual Method for Decommissioning of Weli

\section{Piacement Depth in Feet} From 30

5a. Well Casing Size:

$2^{n}$

inereby certify that the information provided on this forn is true and accurate to the best of my knowledge.

Lebster gelt servers Inc. Byi

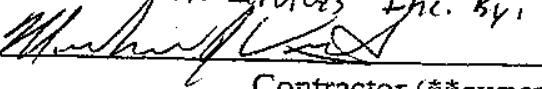

Contractor (**owner)

$$
8-12-11
$$
Bentonite Grout Slurry concreke cap

$\because$ :Owner may sign on wells prior io $7 / 1 / 2001$ or sandpoint or if well no longer exists and it is unknown when decommissioning ficeted
} N/A
1 North, Range feet from the (EQW $\square$ ) section line.

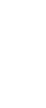




\section{STATE OF NEBRASKA \\ DEPARTMENT OF NATURAL RESOURCES}

\section{NOTICE OF WATER WELL DECOMMISSIONING}

This form is required to be filed within 60 days of decommissioning of the water weil.

\section{FOR DEPARTMENT USE ONLY}

Date Filed $8 / 16 / 11$ Owner Code No. 60538 Registration No. $-N A$ 08162011 - $212252-$ DECF LOWER PLATE SOUTH NRD Well ID

1. Well Owner's First Name

or Company Name United Stakes Dept of Agrulture

Attention Name

Address 1400 Independance Are $5 \mathrm{~m}$ Room 4719 City washrongtow State $\Delta c$ Zip 29250 Telephone

2. Contractor (if applicable). hebster hell Servecs the Address P.O. Bax 128

City Mars BlvEF State $\mathcal{N E}$ Contractor License No. 39495

Email: wwsionits.met

3a. Well Registration No.

3b. Purpose of Well:

3c. Date Well Last Operated.

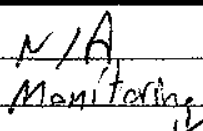

3d. Date of Decommissioning.

$-7-\mid 1-11$

3e. List complete well location: Legal, Footage and/or GPS Coordinates

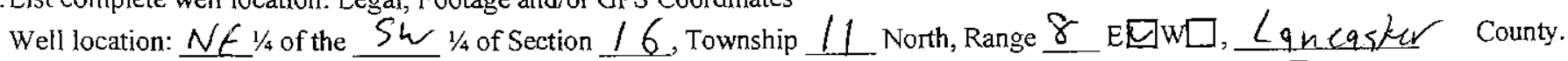

The well is feet from the (N $\square$ or $\mathrm{S} \square$ ) section line and feet from the (E$\square W \square$ ) section line.

OR Latitude Degree: _ $\quad 40$ Longitude Degree: $-9$ $/ / 4$
Minute: 55 Minute: $\quad 31$ Second: 17.00 Second: $55 \cdot 59$

3f. Location of Water Use:

4. Actual Method for Decommissioning of Well

\begin{tabular}{|c|c|c|}
\hline Placement Depth in Feet & \multicolumn{1}{|c|}{ Detailed Description of Material } \\
\hline 55 & To & Bentanite Grout S/urry \\
\hline 6 & 6 & Concrete Cap \\
\hline 5 & 5 & Natwe Soi \\
\hline
\end{tabular}

5a. Well Casing Size: $\quad 2^{k} \quad$ 5b. Bore Hole Diameter: $U n K$

I hereby certify that the information provided on this form is true and accurate to the best of my knowledge.

hebser, well seryikes Inc. By:
If usen Contractor
Contractor (**owner)
$8-|2-1|$
Date

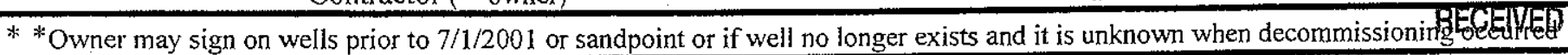


Submit to:

Depariment of Naiural Resources 301 Centennial Mall South

P.O. Box 04676

Lincoln. Nebraska 68509-4676

Phone (d02) 4712363
Oct 2007

DNR DECO

STATE OF NEBRASKA
DEPARTMENT OF NATURAL RESOURCES

This form is required to be filed within 60 days of decommissioning of the water well.

\section{NOTICE OF WATER WELL DECOMMISSIONING}

\section{FOR DEPARTMENT USE ONLY}

Date Filed $8|16| \mathrm{U}$ 08162011 $-\frac{212253}{\text { Well ID }}$ Owner Code No. DECF Registration No. $N A$ LOWER PUTIE SOUTH NRD

I. Well Owner's First Name

OR Company Name USDA

Last Name

Attention Name

4diress 1400 Independance Ane sw Room 4719

city hashington state $D C$ Zip 20250 Telephone

2. Contiactor (if applicable). hebster hell Services Inc Address Pro pox 128 City Merse Bleff

\section{Emaij: husi anntc. net}

3a. Well Registration No.

36. Purpose or Well: $N / A$ Manitoring

3r. Date Weil Last Operated. Unk

3d. Date of Decommissioning. $7-11-11$

3e. List complete well location: Legal, Footage and/or GPS Coordinates

Well location: NE $1 / 4$ of the SW $1 / 4$ of Section $/ 6$, Township

The well is feet from the ( $N \square$ or $S \square$ ) section line and

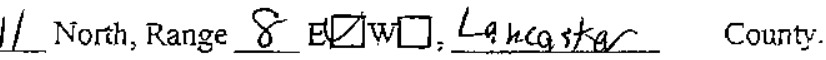
feet from the ( $E \square \mathrm{W} \square$ ) section inine.
OR Latitude Degree: Longitude Degree:
40 $-96$ Minute: 55 Second: $17, \infty$ Second: $55 \cdot 58$

3f. Location of Water Use: $N / A$

4. Actual Method for Decommissioning of Well

\begin{tabular}{|c|c|c|}
\hline $\begin{array}{l}\text { Piacement Depth in Feet } \\
\text { From }\end{array}$ & To & Detailed Description of Material \\
\hline 84 & 6 & Bentontte Greut Slurn \\
\hline 6 & 5 & Concrese cal \\
\hline 5 & 6 & Native Sorll \\
\hline & & \\
\hline
\end{tabular}

5a. Wiell Casing Size:

5b. Bore Hole Diameter:

$u_{n} K$

Thereby certify that the information provided on this forn is true and accurate to the best of my knowledge.

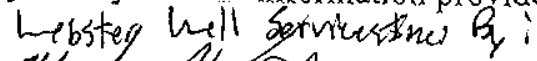

Iftersteg ofl serve

Contractor (** owner)

$$
\frac{8-12-4}{\text { Date }}
$$

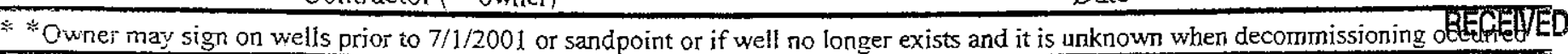


Submit to:

Depariment of Natural Resources

in I Centennial Mall South

P.O. Box 94676

Phone (402) 471 2363
Lincoln. Nebraska 68509-4676

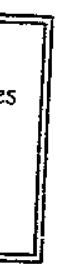

Oct 2007

DNR DECO

STATE OF NEBRASKA
DEPARTMENT OF NATURAL RESOURCES

NOTICE OF WATER WELL DECOMMUSSIONING

\section{FOR DEPARTMENT USE ONLY}

Date Filed 811611 Owiner Code No.

08162011

$$
-\frac{212254}{\text { WelI ID }}
$$

60538

Registration No.

Lower Putte SOUTH

$\sqrt{A}$

This form is required in be filed

within 69 days of decommissioning

of the water well.

1. Welì Owner's First Name

PR Company Name USAA

Attention Narne

Adjiess 1400

Sity washington Independance state $\cap C$ Last Name

2. Contractor (if applicable). hebstor hull Services Ine Address $p B_{c} b_{c} 128$ City Mers Bluff Emaii:-noes a nutc-net S. W. Reom 4719 Zip 26250 Telephone

32. Weil Registracion No.

3. Purpose of Weil:

3c. Daîe Weill Last Operated. UnK

3e. List compleie well location: Legal, Footage and/or GPS Coordinates

The well is

f the State $N$ t $\frac{N / A}{\text { Manitarins }}$

$1 / 4$ of Section 16 , Township. feet from the (N口or $S \square$ ) section line and

$1 /$ North, Range Telephone Number(402) $666-9222$ Contractor License No. 39495
OR Latitude Degree:
Longitude Degree
40
$-96$
Minute:
55 Minute:
Second: $16 \cdot 36$ Second: 51.55

3ิ. Location of Water Use:

$N \angle A$

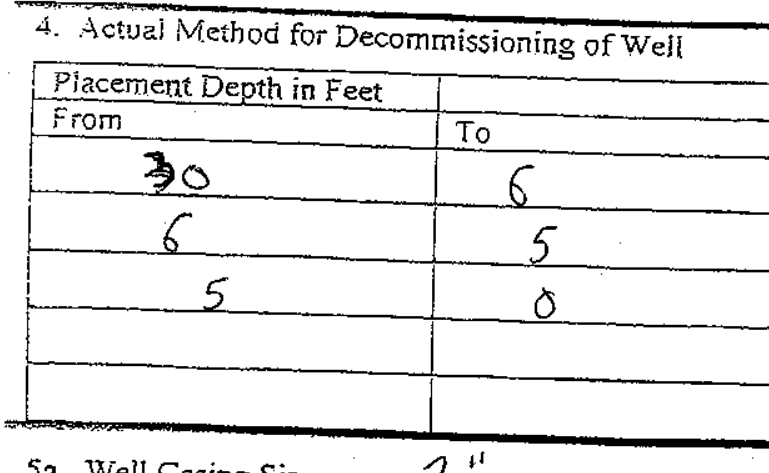

5a. Wiell Casing Size:

$2^{\prime \prime}$

5b. Bore Hole Diameter:

Detailed Description of Material

Bentonite Grout Slurry Concreke Cap

Thereby certify that the information provided on this form is true and accurate to the best of my knowledge.

nebster hell, Servites Inc By:

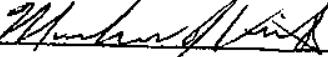
Contractor (**owner)
$\sin 12$
Date

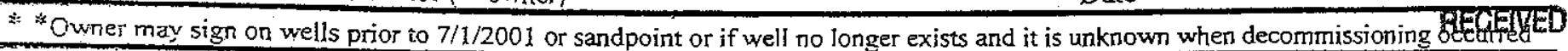

The Department reserves the right to request verification of information provided. 
Submit to:

Depariment of Natural Resources

3.1 Centennial Mall South

P.O. Box 94676

Lincoln. Nebraska 68509-4676

Phone (402) 4712363

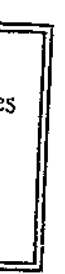

\section{NOTICE OF WATER WELL DECOMMUSSIONING}

Oct 2007

DNR DECO

This form is required to be filed within 60 days of decommissioning of the water well.

\section{FOR DEPARTMENT USE ONLY}

Date Filed $8 / 16 / 11 \quad$ Owner Code No. 60538 Registration No.

08162011 $=\frac{212255}{\text { Well ID }}$

1. Weli Owner's First Name

OR Company Name U USDA

Aitertion Name

Adiess 1400 Independance Ave Sw Room 4719

City washmten State D.

Zip 20250 Telephone

2. Contractor (if applicable). Luebster hell Servies Inc_Lelephone Number(102 666-9zz2

Address P.Q. hoe 128

City Morse BluFE

Emaij: Wwsianntchet

Last Name

3a. Weil Registration No

32. Purpose of Well:

$N \angle \mathbb{A}$

3c. Date Well Last Operated. Menitiona

selistcompletewk

3d. Date of Decommissioning.

$7-11-11$

3e. List complete well location: Legal, Footage and/or GPS Coordinates

Weli location: $N E^{i / 4}$ of the SL 1/4 of Section 16. Township 11 North, Range 8 E[Gw口, Lameaster County.

The well is feet from the (N $\square$ or $S \square$ ) section line and

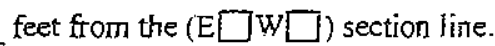

OR Latitude Degree: 40 Longitude Degree: -96

3ิ L Locañon of Water Use:___ N/A

Minute: $\quad 55$

Second: $15 \cdot 32$ Second: $57 \cdot 36$

4. Actual Method for Decommissioning of Well

Piacement Depth in Feet

From

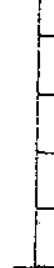

5a. Well Casing Size:

$\frac{6}{5}$

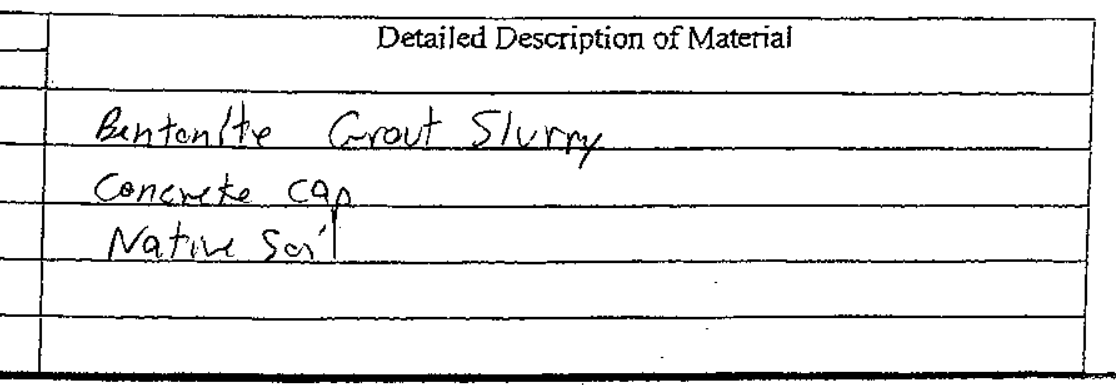

$2^{n}$

5b. Bore Hole Diameter:

UhK

I hereby certify that the information provided on this form is true and accurate to the best of my knowledge.

nebster helj Services Inc. By:

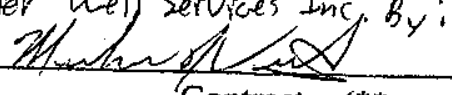

Contractor (**owner)

$$
8-12-14
$$




\section{NOTICE OF WATER WELL DECOMMISSIONING}

This form is required to be filed within 60 days of decommissioning of the water well.

\section{FOR DEPARTMENT USE ONLY}

Date Filed 08162011

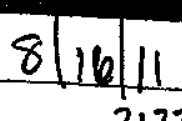
$-\frac{212256}{\text { Well ID }}$
Owner Code No. - DECF
Registration No.

LOWER PLATE SOUTH

i. Well Owner's First Name

PR Company Name_L USDA Last Name

Attention Name

Address 1400 Independance Ave S.w Roon 4719

City hashimston State $0 . C$ Zip 20250 . Telephone

2. Contractor (if applicable). hebster hall Sevures Inc Address - Ro- $80 x-128$ City Marsi Bluff Emaij:Lavsignnte. nt

3z. Weil Registration No

36. Purpose of Weil: State $N t_{1}$ Zip Code 68648

3c. Date Well Last Operated

ic. is ist complete well location: Legal, Footage and/or GPS Coordinates

Well location: $N \in 1 / 4$ of the SW $1 / 4$ of Section 16 , Township

The we!l is feet from the (N口 $\square$ or $S \square$ ) section line and

OR Latitude Degree: $\quad 40$

3r. Location of Water Use:
Minute: Minute:
Second: 15.33 Second: 53.00

\section{Actual Method for Decommissioning of Weil}

\begin{tabular}{|c|c|c|}
\hline Placement Depth in Feet & \\
\hline From & To & Detailed Description of Material \\
\hline 30 & 6 & Contonite Cout Slum cap \\
\hline 6 & 5 & Natwe Sol' \\
\hline 5 & 0 & \\
\hline & & \\
\hline
\end{tabular}

I hereby certify that the information provided on this form is true and accurate to the best of my knowledge.

hebsker hill/ Servyes Ine: By:

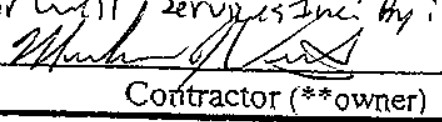

$$
8-12-11
$$


STATE OF NEBRASKA
DEPARTMENT OF NATURAL RESOURCES

NOTICE OF WATER WELL DECOMMUSSIONING

This form is required to be filed within 60 days of decommissioning of the water wiell.

\section{FOR DEPARTMENT USE ONLY}

Daie Filed 811611 08162011

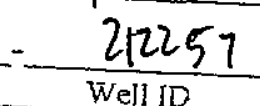

Owner Code No.

DeCF
60538 Registration No. LOWER PUTE SOUTH

1. Well Owner:s First Name

OR Company Name $\quad U S D A$

Attention Name

Address 1400 Last Name

City washibaton

Indefendanae

The Sh Roem 4719 State D.C Zip 20250 Telephone

2. Contractor (if applicable). websker holl Servizes. Ins Address PrQ Bot 128 City Morse bluts

Emait:-awsi D mutc shet Telephone Number(4024 666-9222 Contractor License No. 39495

32. Well Registration No

3c. Purpose of Weil: State NE Zip Code $68648 \div$

ic. Date Well Last Operated.

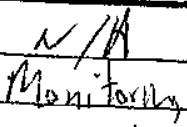

3e. List complete well location: Legal, Footage and/or GPS Coordinates

Thell location
The well is $N \underline{E} i / a$ of the SW $1 / 4$ of Section 16 , Township. feet from the (ND or $S \square$ ) section line and North, Range 8 EGWL, Laucaster County.

OR Latitude Degree: $\quad 40$ Longitude Degree: $\quad-96$ Minute: $\frac{55}{31}$ Second: 15.34 feet from the ( $E \square w \square)$ section line.

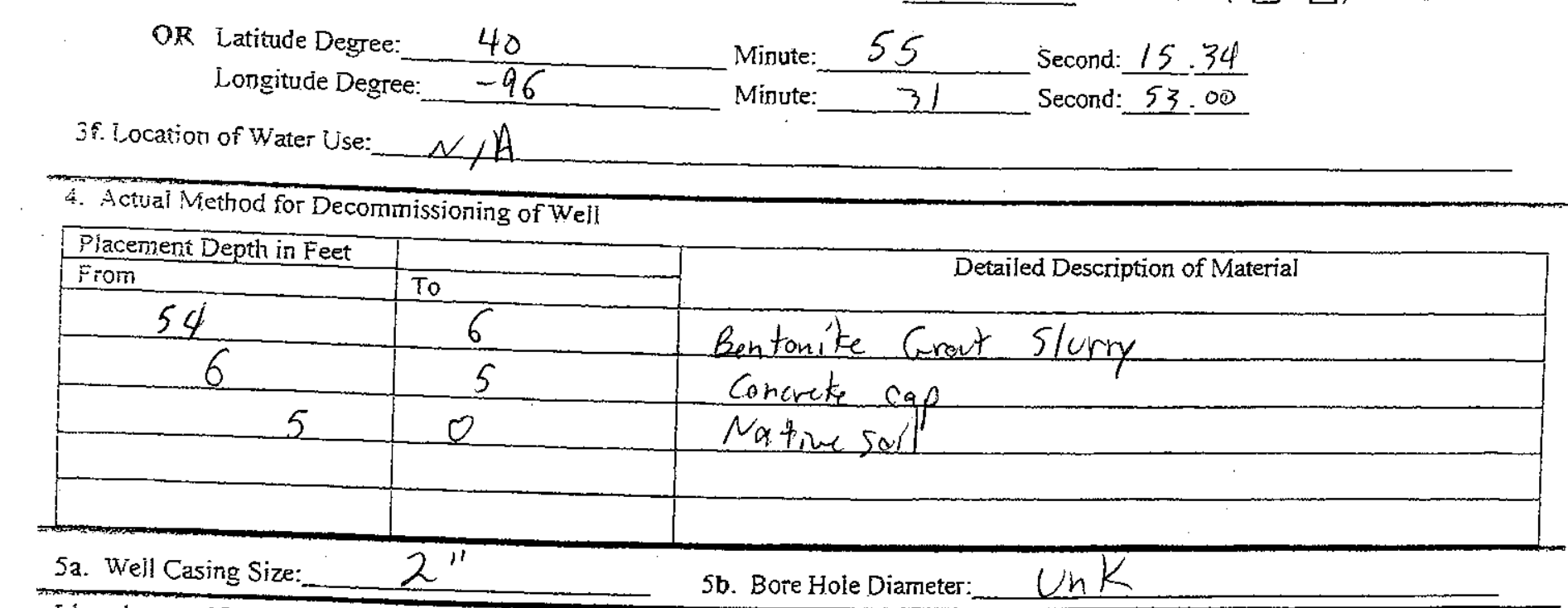

Thereby ceriffy that the information provided on this form is true and accurate to the best of my knowledge.

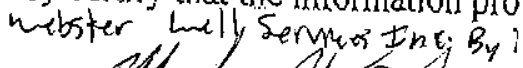
$\frac{\text { Pfucher }}{\text { Contractor (**owner) }}$
$8-12-11$
Date

PIESENED

$\because$ : Owner may sign on wells prior to $7 / 1 / 2001$ or sandpoint or if well no longer exists and it is unknown when decommissioning occurred 


\section{Submit to:}

Depariment of Natural Resources

301 Centennial Mall South

P.D. Box 04676

Lincoln. Nebraska 68509-4676

Phone (402) 4712363

\section{STATE OF NEBRASKA \\ DEPARTMENT OF NATURAL RESOURCES}

Oct 2007

DNR DECO

NOTICE OF WATER WELL DECOMMUSSIONING

\section{FOR DEPARTMENT USE ONLY}

Daie Filed_ $8116 / 11$ Q8162011

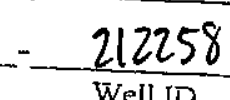

Owner Code No. DECf
60538 Registration No.

1. Well Owner"s First Name

QR Company Name L L D A

Last Name

Attention Name

Address $k 100$ Independance Ave SW Room 4719

ciry luashmeton State

Zip 20250 Telephone

2. Contiactor (if applicable). Webster hell Services the Address P Q Bei 128 City Mor3l Bluff

Email:-whsiQ hntc net

3a. Weil Registration No.

32. Purpose of Weil: State $N e$ Zip Code $68648+$

This form is required to be filed within 60 days of decommissioning of the water well.

ir. Date Weil Last Operated. Mentong

unk

3e. List complete well location: Legal, Footage and/or GPS Coordinates

Weli location: $S E$ i/4 of the $N W$ i/a of Section $/ 6$, Township I/ North, Range 8 E

The well is feet from the (N口 $\square$ or $S \square$ ) section line and

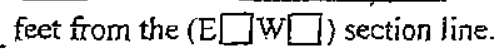

OR Latitude Degree Longitude Degtee $-40$ Minute: Minute: 55 N/A

35. Location of Water Use Second:22.00 Second: 50.00

4. Actuai Method for Decommissioning of Well

\begin{tabular}{|c|c|c|}
\hline piacement Depth in Feet & & \\
\hline 27 & To & Detailed Description of Material \\
\hline 6 & 6 & Bentonite Creut Slurm \\
\hline 5 & 5 & Concrete cap \\
\hline & 0 & Nathe Sol \\
\hline & & \\
\hline
\end{tabular}

5a. Wiell Casing Size: 2

Sb. Bore Hole Diameter:

whK

I hereby cerify that the information provided on this form is true and accurate to the best of my knowledge.

hebstor well serviess Incyby:

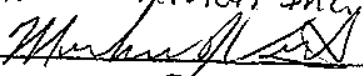

Cbotractor (**owner)

$8-12 r 11$

\section{Date}

* Owner may sign on wells prior to $7 / 1 / 2001$ or sandpoint or if well no longer exists and it is unknown when decommissioning occultedEVED 
Submit to:

Department of Natural Resources

inl Centcrnial Mall South

P.O. Box 9.4676

Lincoln. Nebraska 68509-4676

Phone (402) 47I 2363

\section{NOTICE OF WATER WELL DECOMMISSIONING}

STATE OF NEBRASKA

DEPARTMENT OF NATURAL RESOURCES
Oct 2007

DNR DECO

This form is required in be filed within 60 days of decommissioning of the water well.

\section{FOR DEPARTMENT USE ONLY}

Daie Filed $8116 / 11$ 08162011 $-\frac{212259}{\text { WeII ID }}$ Owiner Code No. $\quad 60538$ Registration No. LOWER PUTE SOUTH NA Decf NRD

i. Well Owner:s First Name

OR Company Name $\quad \angle S D A$ Last Name

Attention Name City hashinston State D.C Zip 20250 Telephone

2. Contractor (if applicable). Webster well Sexvices Ine Telephone Number $402666-9222$ Address Po bex 129

city Marse Bluff

Email: whsionnternet Contractor License No. 39495

3z. Weil Registration No.

3. Purpose of Well:

3. Date Well Last Operated. Mentong

3e. List complete well location: Legal, Footage and/or GPS, Coordinates

Weli location: $S E_{1 / 4}$ of the $\mathcal{N} W_{1 / 4}$ of Section $/ 6$, Township

The well is feet from the (N口or $S \square$ ) section line and

11 North, Range \& EDWD, Cancarter County.
OR Latitude Degree: Longitucie Degree: 40 Minute: $\quad 55$

$\frac{40}{-96}$ Minute: $\frac{55}{31}$ Second: 22.03
feet from the ( $E \square w \square)$ section ine.

3. tocation of Water Use:

\begin{tabular}{|c|c|c|}
\hline Placement Depth in Feet & & \\
\hline From & To & Detailed Description of Material \\
\hline 53 & 6 & Bentonite Grout Slurry \\
\hline 6 & 8 & Concme Cao \\
\hline 5 & 0 & Native So'l \\
\hline & & \\
\hline 52. Well Casing Size: & $2^{\prime \prime}$ & 5b. Bore Hole Diameter: $-\quad$ Un $/ K$ \\
\hline
\end{tabular}

Thereby certify that the information provided on this form is true and accurate to the best of my knowledge.

webster hell services tinc. By?

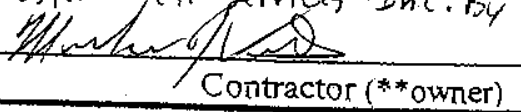

$$
\frac{8-1211}{\text { Date }}
$$

* * Owner may sign on wells prior to $7 / 1 / 2001$ or sandpoint or if well no longer exists and it is unknown when decommissioning occuuted 
Submit to:

Department of Nazural Resources

5ll Centennial Mall South

P.O. Box 04676

Lincoln. Nebraska 68509-4676

Phone (402) 47\} 2363

\author{
STATE OF NEBRASKA \\ DEPARTMENT OF NATURAL RESOURCES
}

Oct 2007

DNR DECO

This form is required to be filed within 60 days of decommissioning of the water well.

\section{NOTICE OF WATER WELL DECOMMASSIONING}

\section{FOR DEPARTMENT USE ONLY}

Date Filed $8116 / 11$ o8162011

$$
=\frac{212260}{\text { Well ID }}
$$

Owiner Code No. - DECF
60538 Registration No. LOWER PUTTE SOUTH

1. Well Owner:s First Name

OR Company Name (LSDA Last Name

Attention Name

Address

city Washrington

Independance AVe state $D_{1} C_{2}$

Raom 4719

2. Contractor (if applicable). hebster hell Servives Inc Adidress City Marse Bluff Email:uwsienntc, net State NE

Telephone Number(482) $666-9222$ Contractor License No. $\quad 39495$

3a. Weil Registration No.

3⿻. Pirpose of Well:

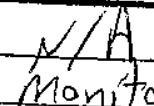

3c. Date Weil Last Operated. Monitoning

3c. List complete well location: Legal, Footage and/or GPS Coordinates

Well location: $S t \quad 1 / 4$ of the $N$ W $1 / 4$ of Section 16, Township

The well is feet from the (N口or $\mathrm{S} \square$ ) section line and Zip Code $68648+$ Zip 20250 Telephone
OR Latitude Degree: Longitude Degree:
40
$-96$ Minute: $\frac{55}{31}$ Second: 22.07 Second: 50.00

3. Tocation of Water Use: $N, A$

4. Actual Method for Decommissioning of Weil

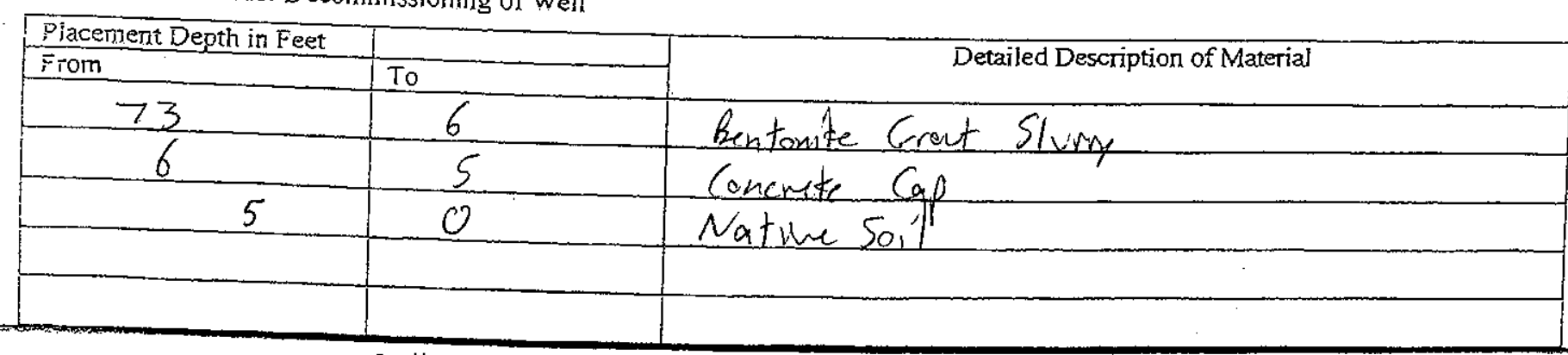

5a. Wiell Casing Size:

$2^{11}$

5b. Bore Hole Diameter:

ink

Inereby certify that the information provided on this form is true and accurate to the best of my knowledge.

uibster lugll semings Ime By:

$$
\frac{8-12-\mid 1}{\text { Date }}
$$

$\because$ * Owner may sign on wells prior to 7/1/2001 or sandpoint or if well no longer exists and it is unknown when decommissioning occurefled 


\section{STATE OF NEBRASKA DEPARTMENT OF NATURAL RESOURCES}

\section{NOTICE OF WATER WELL DECOMMUSSIONING}

\section{FOR DEPARTMENT UUSE ONLY}

Date Filed $8 / 16 / 11$ Q8162011- $-\frac{212261}{\text { Well ID }}-$ DECF

60538 Registration No. LOWER PUTE SOUTH NRD

i. Well Owner:s First Name

OR Company Name__ USDA

Attention Name

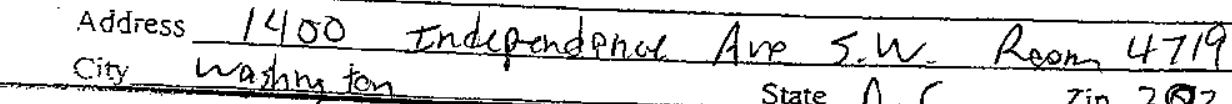
State $0 . C$ Zip 20250 Telephone

2. Contractor (if applicable). heloster hell Servives Inc Address $P . Q$ bet 128 City Mors Bluf Emaii:hwsiantine Last Name

This form is required io be filed within 60 days of decommissioning of the water well.

Telephone Number 402$) 666-9222$ Contractor License No. 39495

3a. Weil Registration No.

3. Purpose of Well: $N /$ A

3c. Daîe Well Last Operated. Lnk

3c. List complete well location: Legal, Footage and/or GPS Coordinates

Well location: $S E$ i/4 of the $N W^{3 / 4}$ of Section 16 , Township $1 /$ North, Range 8 EUw口, Lancas ter County. The well is feet from the (N口or $S \square$ ) section line and

OR Latitude Degree: Longitude Degree: $-40$ Minute: $\quad 55$ Second: 22.11 Second: 50.00

\section{I Location of Water Use:} $N / A$

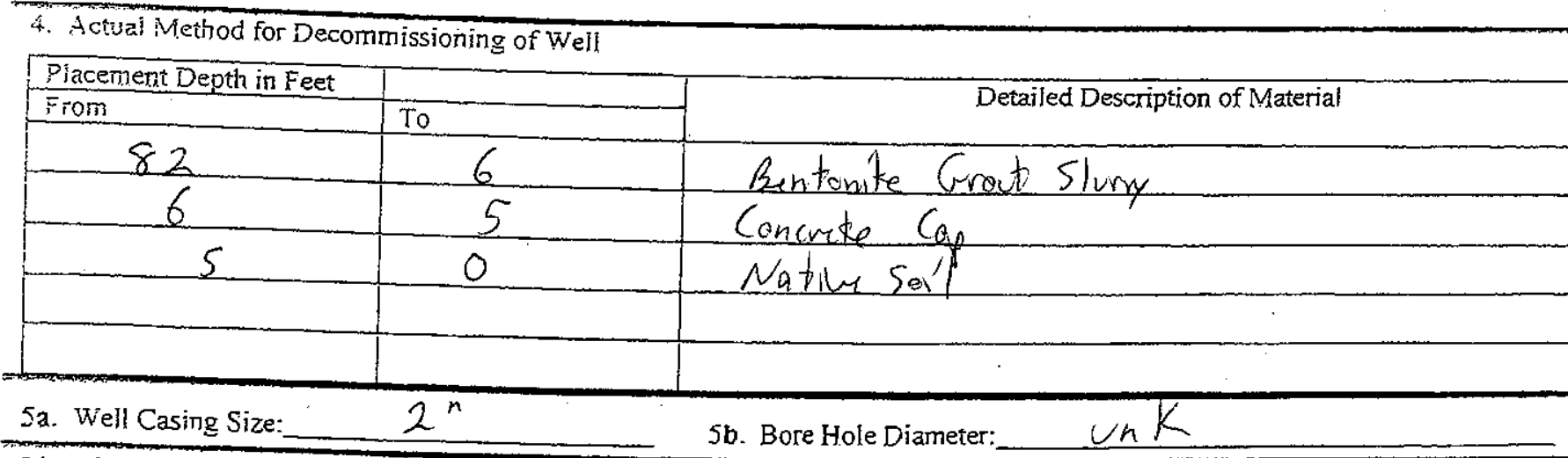

Thereby certify that the information provided on this form is true and accurate to the best of my knowledge.

wibiter hyll servies Inc $B_{y}$ :

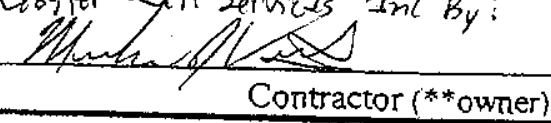

$$
\frac{8-12-1 \mid}{\text { Date }}
$$

$*$ Owner may sign on wells prios to $7 / 1 / 2001$ or sandpoint or if well no longer exists and it is unknown when decommissioning occurred 


\section{NOTICE OF WATER WELL DECOMMUSSIONING}

This form is required in be filed within 60 days of decommissioning of the water well.

\section{FOR DEPARTMENT USE ONLY}

Daîe Filed

$8 / 16] 11$

08162011

$$
-\frac{212262}{\text { Well }}
$$

Owner Code No. $\quad 60538$

- DECF
Registration No.

NA

LOWER PUTTE SOUTH

I. Well Owner's First Name

$\mathrm{OR}$ Company Name__ $\angle 5 D A$

Last Name

Attertion Name

4diress _ 1400

city hashiviton Independano

Ave Sw Reom 4719 State $D, C \quad$ Zip 20250 Telephone

2. Contractor (if applicable) webster hall Servius Inc

City Morse Bluef

Email: wusionute net

Telephone Number 402 666-9222

Contractor License No. 39495

32. Weil Registration No.

3. Purpose of Well: State NG. Zip Code $68648 \mp$

Zc. Daîe Well Last Operated.

$$
N / A
$$

3e. List complete well location: Legal, Footage and/or GPS Coordinates

Well location: $S E$ i/4 of the $N W$ 1/a of Section 16 , Township

The we!l is feet from the (N $\square$ or $S \square$ ) section line and
OR Latitude Degree: $\quad 40$
Longitude Degree: -96 Minute: $\frac{55}{31}$ Second: 2217 Second: 50.00

3t. Location of Water Use: $N A A$

4. Actuai Method for Decommissioning of Weil

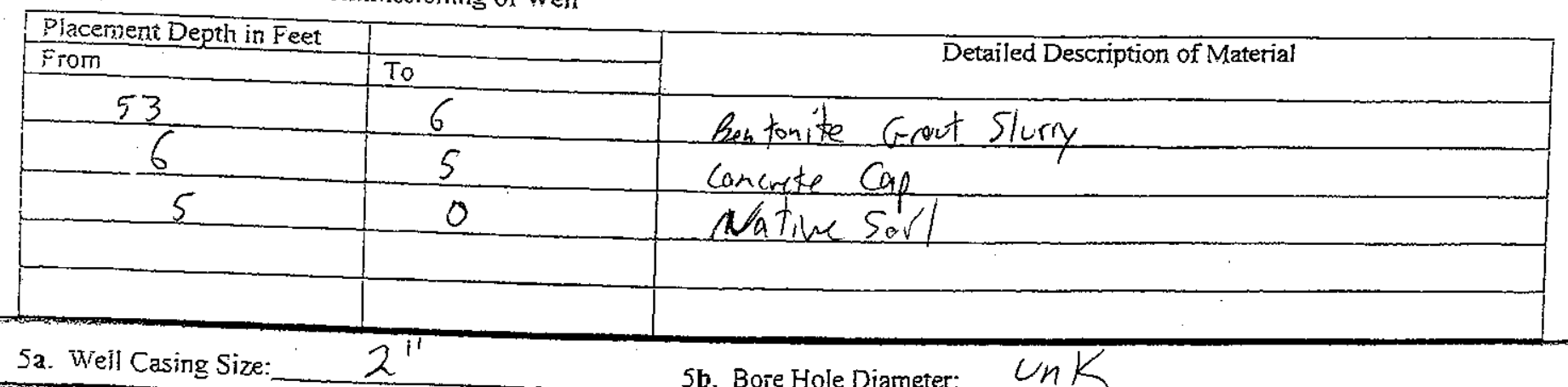

Thereby certify that the information provided on this form is true and accurate to the best of my knowledge.

mebster weld severes Inc By.

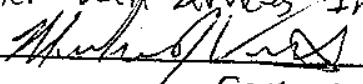

*Owner may sign on wells prior to $7 / 1 / 2001$ or

$8-|z-1|$

The Department reserves the right to request verification of information provided.

AECENUED

AUG 162011 
STATE OF NEBRASKA

DEPARTMENT OF NATURAL RESOURCES

Oct 2007

DNR DECO

\section{NOTICE OF WATER WELL DECOMMUSSIONING}

\section{FOR DEPARTMENT USE ONLY}

Date Filed $8 / 16 / 11$ 08162011 $-\frac{212263}{\text { Well ID }}$ Owner Code No. $\quad 60538$ - DECF Registration No. LOWER PUTTE SOUTA $\sqrt{A}-$

This form is required to be filed within 60 days of decommissioning of the water well.

1. Well Owner's First Name

$O R$ Company Name USDA

Attention Name

Adiress 1400 City washinton Last Name Independance $\begin{array}{cc}\text { Ave S.w Room } 4719 \\ \text { state } 0 . C & \text { Zip } 20250\end{array}$ Telephone

2. Contractor (if applicable). hebster ladl Servives Ine Address P.O Bat 128 City Mor's blusf Emaii: husionitr.ax State $N \epsilon$ Telephone Number 4026669222 Contractor License No. 39495

3r. Weil Registration No.

32. Purpiose of Well:

$$
\text { Men } / A
$$

3c. Date Well Last Operated $1 \ln k$ 3d. Date of Decommissioning $7-11-1 \mid$

3e. List complete well location: Legal, Footage and/or GPS Coordinates

weli location: $S E$ i/a of the $N W 1 / 4$ of Section 16 , Township The well is feet from the (N口or $S \square$ ) section line and
Norih, Range \& EXJw] Lancaster County.

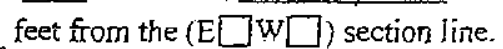
OR Latitude Degree: Longitude Degree: Minute: 55 Minute: Second: 18.00 Second: 56.28

3f. I- ocation of Water Use: $N A A$

4. Actuai Method for Decommissioning of Well

\begin{tabular}{|c|c|}
\hline Placement Depth in Feet & \\
\hline From & To \\
\hline 28 & 6 \\
\hline 6 & 5 \\
\hline 5 & 5 \\
\hline
\end{tabular}

Thereby certify that the information provided on this form is true and accurate to the best of my knowledge.

nebster gull serviestne By.

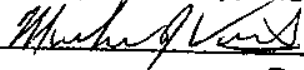




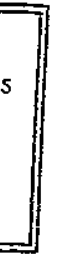

Oct 2007

DNR DECO

\begin{tabular}{c|c|} 
STATE OF NEBRASKA & $\begin{array}{l}\text { This form is required to be filed } \\
\text { within } 60 \text { days of decommissioning } \\
\text { of the water well. }\end{array}$ \\
\hline DEPARTMENT OF NATURAL RESOURCES
\end{tabular}

\section{NOTICE OF WATER WELL DECOMMUSSIONING}

\section{FOR DEPARTMENT USE ONLY}

Daie Filed 8116$) 11$ O8162011

\section{- 212264}

Well ID
Owiner Code No. 60538 Registration No.
LOWER PUAHE SOOTH

i. Well Owner's First Name

OR Company Name USDA

Last Name

Attertion Name

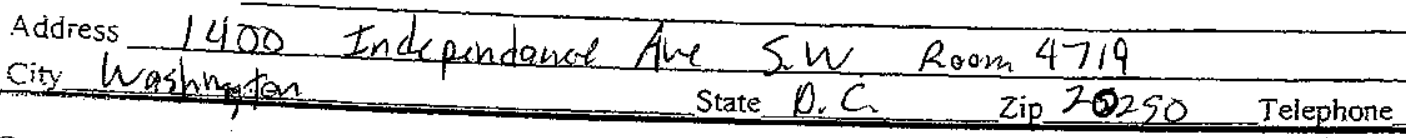

2. Contractor (if applicable). Webster hell Servizes Inc Telephone Number(joz) $666-9222$

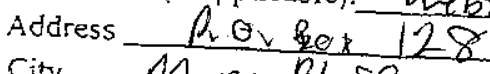

City Marse Bluff

Emaiinusionnte, het Contractor License No. 39495

3a. Well Registration No.

32. Purpose of Weil: State NG. Zip Code 68648

3c. Date Weil tast Operated Mandtoring

\section{3r. List complete well location: Legal, Footage and/or GPS Coordinates}

Weli location: St $1 / 4$ of the $N w_{1 / 4}$ of Section 16 , Township.

The well is feet from the (N口or $S \square]$ ) section line and

North, Range \& EDw $\square$, Lancaster County.

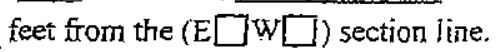
OR Latitude Degree: Longitude Degree:
40
$-96$ Minute: $\frac{55}{31}$ Second: $\frac{18}{56} \cdot \frac{\infty}{10}$

3. Location of Water Use: N/A

4. Actual Method for Decommissioning of Well

\begin{tabular}{|c|c|c|}
\hline $\begin{array}{l}\text { Placement Deoth in Feet } \\
\text { From }\end{array}$ & To & Detailed Description of Material \\
\hline 52 & 6 & Bentonite Grout Slury \\
\hline 6 & 5 & Concrete cap \\
\hline 5 & $\mathcal{O}$ & native sól \\
\hline & & \\
\hline
\end{tabular}

5a. Well Casing Size:

$4^{n}$

5b. Bore Hole Diameter:

unk

I hereby certify that the information provided on this form is true and accurate to the best of my knowledge.

webster hell fervices tha By.

Mekpen of ting

Contractor (**owner)

$8-12-4$

\section{Date}

$\because$ Owner may sign on wells prior to $7 / 1 / 2001$ or sandpoint or if well no longer exists and it is unknown when decommissioning occured

The Department reserves the right to request verification of information provided. 


\begin{tabular}{l} 
Submit to: \\
Depariment of Natural Resources \\
301 Centennial Mall South \\
P.O. Box 04676 \\
$\begin{array}{l}\text { Lincoln. Nebraska 68509-4676 } \\
\text { Phone }(402) 47 \mathrm{j} 2363\end{array}$ \\
\hline
\end{tabular}

\section{NOTICE OF WATER WELL DECOMMISSIONING}

\section{FOR DEPARTMENT USE ONLY}

Date Filed $8 / 16] 11$

08162011

$$
=\frac{212265}{\text { Well ID }}-\text { DECF }
$$

Owiner Code No. 60538 Registration No.

LOWER FUTE SOUTH NRD

1. Well Owner's First Name

OR Company Name

$$
\cup 5 D A
$$

Last Name

Attention Name

Address 1400 Independene Ave Sw Room 4719

City hashington State D.C Zip 20250 Telephone

2. Contractor (if applicable). yabbstec haell Sevvices Inc Telephone Number(402666-9222-

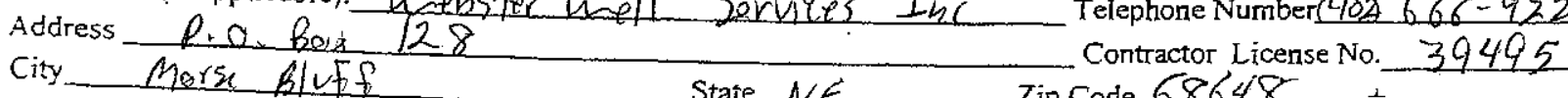

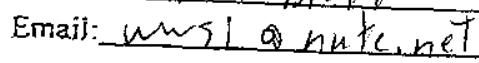
State $N E$ Zip Code 68648

3r. Weil Registration No.

32. Purpose of Well:<smiles>CCC(C)C(C)=C1CCCCC1</smiles>

3ิ. Dâte Well Last Operated. UnK 3d. Date of Decommissioning. $7-11-11$

3e. List complete well location: Legal, Footage and/or GPS Coordinates

Well location: $\Sigma t i / 4$ of the $N W 1 / 4$ of Section $/ 6$, Township.

The we!l is feet from the (N口 or $S \square$ ) section line and

$1 /$ North, Range 8 EDW L Lancaster County.

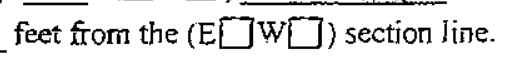
OR Latitude Degree: Longitude Degree: $-40$ Minute: 55 Second: 18.00 Second: 55.50

3र्. Location of Water Use: $N / A$

4. Actual Method for Decommissioning of Well

\begin{tabular}{|c|c|c|}
\hline Piacement Depth in Feet & & \\
\hline 89 & To & Detailed Description of Material \\
\hline 6 & 6 & Contonite Cout Slurry \\
\hline 5 & 5 & Nathl Sol \\
\hline & 0 & \\
\hline
\end{tabular}

I hereby certify that the infomation provided on this form is the and accurate to the best of my knowledge. nebster hell servicestinc. By:

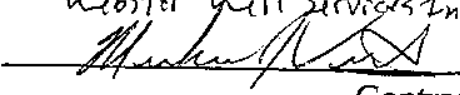
Contractor (**owner)

$$
8-12-11
$$
Date RECENED

$\approx$ *Owner may sign on wells prior to $7 / 1 / 2001$ or sandpoint or if well no longer exists and it is unknown when decommissioning occurred

The Department reserves the right to request verification of information provided. 
Submit to:

Depariment of Natural Resources

inl Cenicnniai Mall South

P.O. Box 94676

Lincoln. Nebraska 68509-4576

Phone (402) 4712363
STATE OF NEBRASKA
DEPARTMENT OF NATURAL RESOURCES

Oct 2007

DNR DECO

This form is required in be filed within 60 days of decornmissioning of the water well.

\section{NOTICE OF WATER WELL DECOMMISSIONING}

\section{FOR DEPARTMENT USE ONLY}

Daie Filed 8116 (11)

Owner Code No.

08162011

$$
-\quad 212266
$$

60538

Registration No.

LOWER PLTIE SOUTH NRD

i. Weli Owner's First Name

OR Company Name C USAA

Attertion Name

Addiess 1400 Independance Ahe S,w Room 4219

City lughington state O. C Zip 20250 Telephone

2. Contractor (if applicable). Lebster hell Serviaes Inc Aüdress P.O Box 128 City Mere Bluff Enaii: ubesionitene

Last Name

3a. Well Registration No.

36. Purpose of Well:

$$
\text { Monfterme }
$$

ż. Dấe Well Last Operated.

un $k$

3d. Date of Decommissioning.

Telephone Number 1046669222

Contractor License No. 39495

3e. List complete well location: Legal, Footage and/or GPS Coordinates

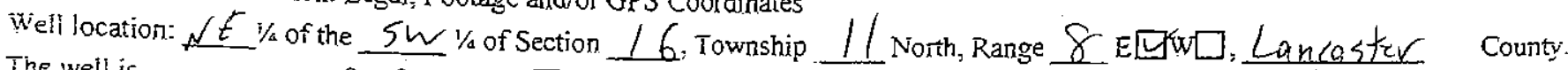
The well is feet from the (N $\square$ or $S \square$ ) section line and feet from the (EDW[ section line.

OR Latitude Degree Longitude Degree:

40 $-96$

3f. Location of Water Use: $\quad N / A$
Minute: 55 Minute:
Second: 05.08 Second: $51 \cdot 41$

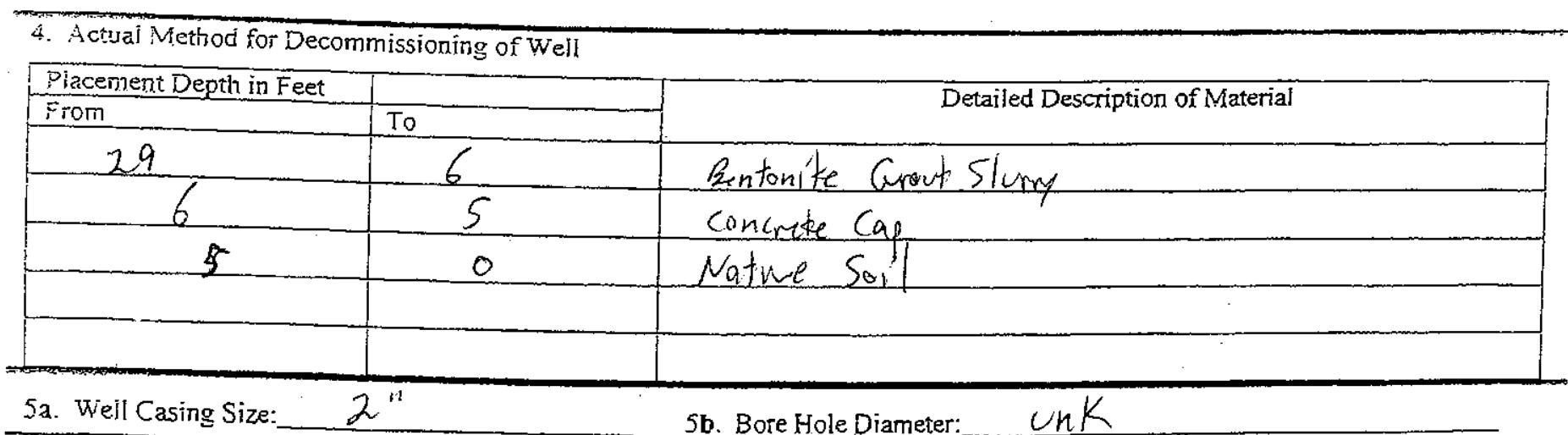

Thereby certify that the information provided on this form is true and accurate to the best of my knowledge.

webster nell servies Ine By?

Hum and as

$$
\text { Contractor (**owner) }
$$$$
8-1211
$$ 
Submit to:

Department of Natural Resources

301 Centennial Mail South

P.O. Box 04676

Lincoln. Nebraska 68509-4676

Phone (402) 47] 2363
Oct 2007

DNR DECO

\author{
STATE OF NEBRASKA \\ DEPARTMENT OF NATURAL RESOURCES
}

This form is reguired to be filed within 60 days of decommissioning of the water well.

\section{NOTICE OF WATER WELL DECOMMISSIONING}

\section{FOR DEPARTMENT USE ONLY}

Date Filed $\quad 8 / 16 / 11$

08162011

$$
-\frac{212267}{\text { Well ID }}-\text { DEC }
$$

Owner Code No.

60538

Registration No.

lower Plutte south $N R D$

1. Well Owner's First Name

PR Company Name

Last Name

Attention Name

Addiess 1400 Independang Awe S.w Room 4719 city hashington State D.e Zip 20250 Telephone

2. Contractor (if applicable). Wrebster hall Serviees Ine Ajdress P.O Bax 128

Gity Marse Bluff

Email: rusionicut net

Telephone Number $/ 02666,9222$ Contractor License No. 39495

3a. Weil Registration No.

3. Purpose of Well:

NA

Monitoring

3x. Date Weil Last Operated. un $<$

State $N E$ Zip Code 68648 $+$

3e. List complete well location: Legal, Footage and/or GPS Coordinates

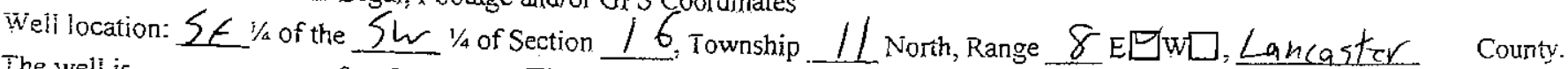

The well is feet from the (N口or $\mathrm{S} \square$ ) section line and feet from the (E口W $\square$ ) section line.
OR Latiude Degree:
Longitude Degree:
Minute: Minute:
55
31
Second: 00.02 Second: 59.38

3. Location of Water Use:

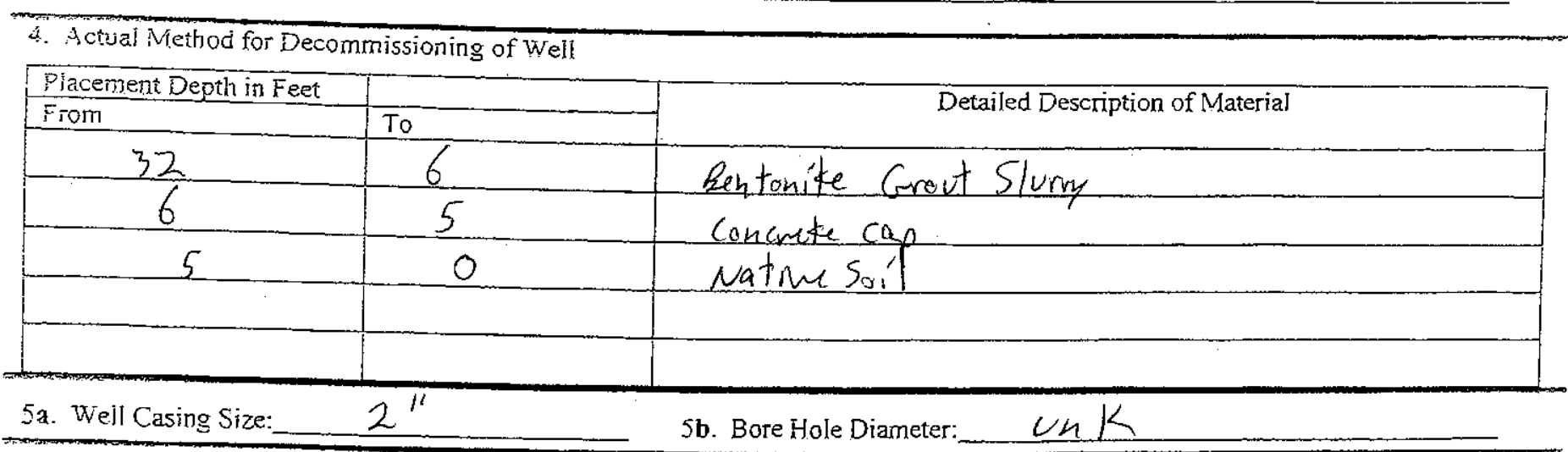

Thereby certify that the information provided on this forn is true and accurate to the best of my knowledge.

webster hedl servies the By:

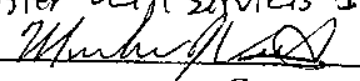

Contractor (**owner)

$$
8-12-11
$$

Date

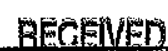

* :Owner may sign on wells prior to $7 / 1 / 2001$ or sandpoint or if well no longer exists and it is unknown when decommissioning occurted

The Department reserves the right to request verification of information provided. AUG 162011 
Submit to:

Department of Natural Resources

301 Centeonial Mall South

Lincoln. Nebraska 68509-4676

Phone (402) 47J 2363
P.O. Box 94676

STATE OF NEBRASKA

DEPARTMENT OF NATURAL RESOURCES

NOTICE OF WATER WELL DECOMMISSIONING

\section{FOR DEPARTMENT USE ONLY}

Date Filed $8[16] 11$

Owner Code No.

60538 Registration No.

\section{1} $-\frac{212268}{\text { Well ID }}$ Decf
Oct 2007

DNR DECO

This form is required to be filed within 60 days of decommissioning of the water well.

1. Well Owner's First Name

OR Company Name_L LSDA

Atiention Name

Address 1400 Independance Ave S.W Reom 4719

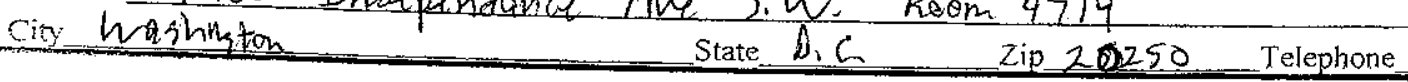

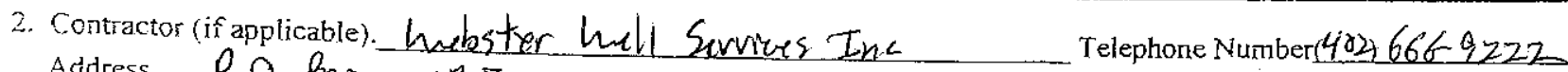

Address $2.0280 x-128$

City Mors Bluff

Email: wrsi Qnntc net

32. Well Registration No.

3t. Purpose of Weil:

$$
\text { Monitame }
$$

3c. Date Weil Last Operated. $\mathrm{VhK}$

3d. Date of Decommissioning. $\quad 7 \sim 11-11$

30. List complete well location: Legal, Footage and/or GPS Coordinates

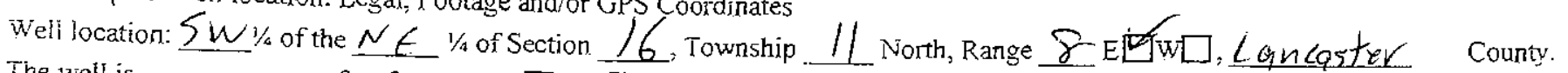

The well is feet from the ( $\mathrm{L} \square$ or $\mathrm{S} \square$ ) section line and

Contractor License No. 39495

State $N E$ Zip Code 68648 feet from the (E[ $[W \square$ ) section Iine.
OR Latitude Degree: ___ 40
Longitude Degree: $\quad-96$
Minute: $\quad 55$ Minute:
31
Second: 26.04 Second: $49 \cdot 59$

3f. Locaition of Water Use:

$1 / A$

4. Actial Method for Decommissioning of Well

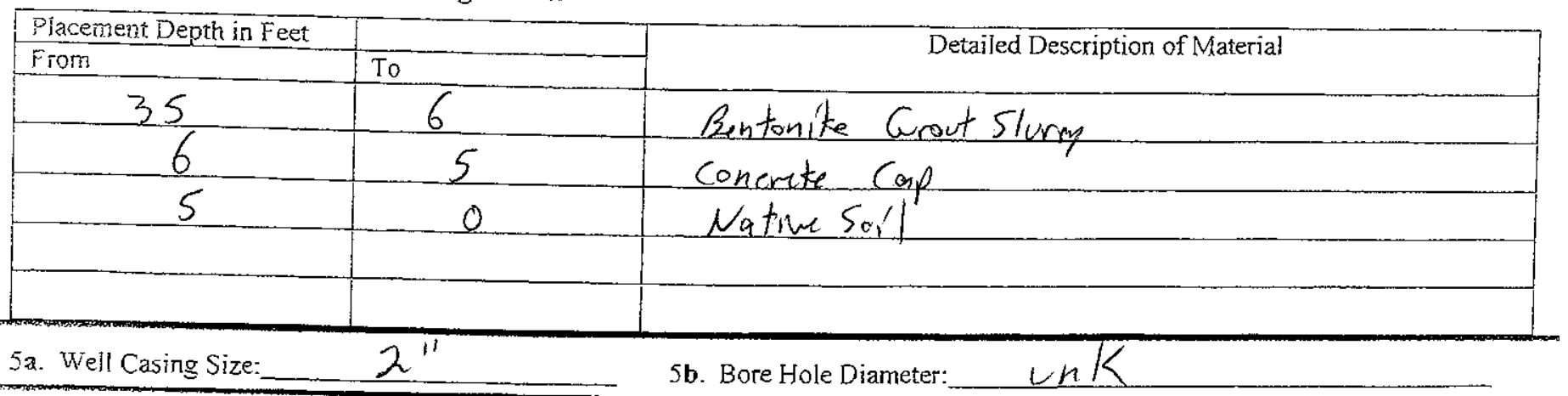

thereby certify that the information provided on this form is true and accurate to the best of my knowledge.

webster yeil serviess tini. By:

Mhellan $\frac{}{\text { Contractor (**owner) }}$

$8-12-11$

Date

* * Owner may sign on wells prior to $7 / 1 / 2001$ or sandpoint or if well no longer exists and it is unknown when decommissioning occuried

The Department reserves the right to request verification of information provided.

AUG 162011 


\section{NOTICE OF WATER WELL DECOMMUSSIONING}

This form is required to be filed within 60 days of decommissioning of the water well.

\section{FOR DEPARTMENT USE ONLY}

Date Filed $8(16 / 11$

08162011

$-\frac{212269}{\text { Well ID }}-$ DECf

Owiner Code No. $\quad 60538$

Registration No.

LOWER PUTEE SOUTH

NRD

1. Well Owner's First Name

OR Company Name USDA

Last Name

Attertion Name

Adiess 1400 Indupendance Ave 5.w

city washingtom State $D, C$

Rocm 4719 Zip 29250 Telephone

2. Contractor (if applicable). Wubstre hall Servives Inc Telephone Number(400) 666 9222 Adidress P.Q Be 128 City Morse Bluff

Emaii: wmsion nnts.net Contractor License No. 39495

3z. Weil Registration No.

3. Purpose of Weil: State $N G$ Zip Code $68648+$

ic. Date Weil Last Operated. Un 3d. Date of Decommissioning. $7-11-11$

3 c. List complere well location: Legal, Footage and/or GPS Coordinates

Weli location: $N W^{i / 4}$ of the $N E$ 1/4 of Section $/ 6$ Township $1 /$ North, Range 8 EW W , Laneaster County.

The well is feet from the (N $\square$ or $S \square$ ) section line and

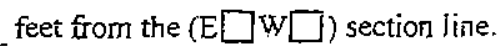
OR Latitude Degree: Longitude Degree:
40 Minute:
55 Second: 35.04 Minute: 31 Second: 49.58

3र. Iocation of Water Use: $N / A$

4. Actual Method for Decommissioning of Weli

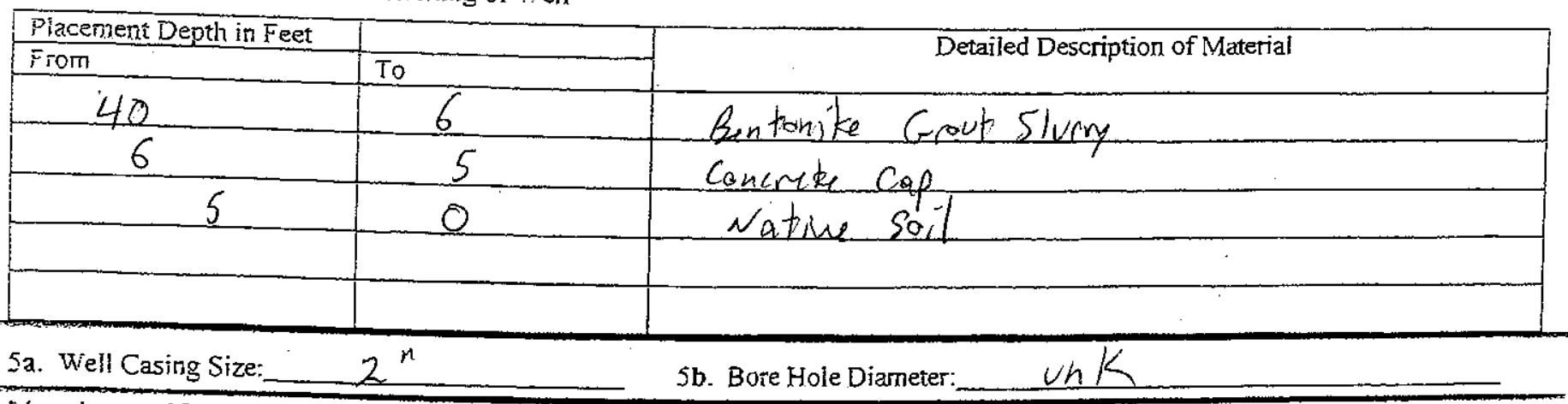

I hereby cerify that the information provided on this form is true and accurate to the best of my knowledge.

unbster hell, serviestina Bu

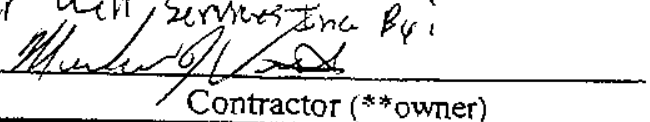

$8-12-1 \mid$ Contractor (**owner) 
Deparment of Natural Resources

501 Centonnial Mall South

P.O. Box 04676

Lincoln. Nebraska $68509-4676$

Phone (402) $471236 j$
STATE OF NEBRASKA

DEPARTMRENT OF NATURAL RESOURCES

This form is required to be filed within 60 days of decommissioning of the water well.

\section{NOTICE OF WATER WELL DECOMMISSIONING}

\section{FOR DEPARTMENT USE ONLY}

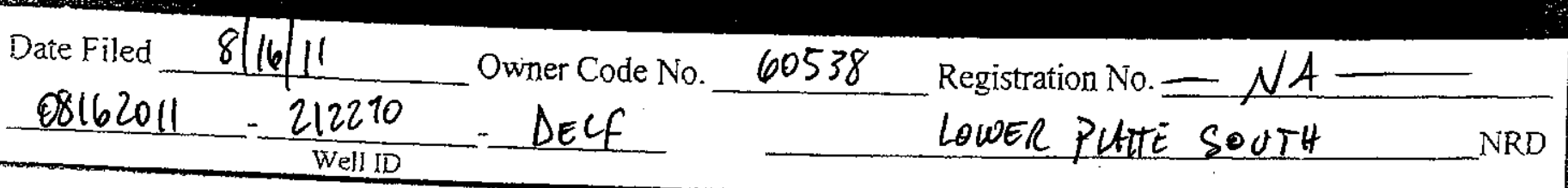

1. Well Owner"s First Name

OR Company Name $\quad \cup \overline{S A}$

Last Name

Attention Name

Address 1400 tndependance Ave Sw Room 4719

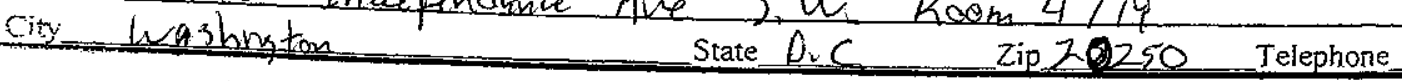

2. Contractor (if applicable). Whebster hell Servies Inc Telephone Number(402666 9222

Address $P Q=B O 128$ Contractor License No. 39495

City Morse Bleff $\quad$ State $N G_{1} \quad$ Zip Code $68648 \div$

3a. Well Registration No.

3b. Purpose of Weil:

§c. Date Well Last Operated.

3d. Date of Decommissioning.

3e. List complete well location: Legal, Footage and/or GPS Coordinates

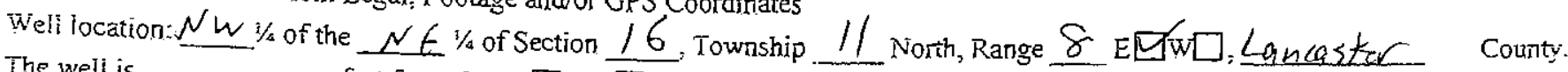

The we!l is feet from the (N口or S $\square$ ) section bine and feet from the (E $\square w \square$ ) section line.
OR Latitude Degree: Longitude Degree:
40 Minute: $\frac{55}{31}$ Second: 43.59 Second: 34.06

3. Location of Water Use:___ N/A

4. Actual Method for Decommissioning of Well

Placement Depth in Feet From

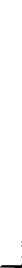

5a. Well Casing Size:

\begin{tabular}{|c|c|}
\hline & To \\
\hline & 6 \\
\hline & 0 \\
\hline & \\
\hline
\end{tabular}

5b. Bore Hole Diameter:__ 내 $\quad$ K Concrete Carp Native Soll

thereby certify that the information provided on this form is true and accurate to the best of my knowledge.

vebstei well sernies Ine: By:

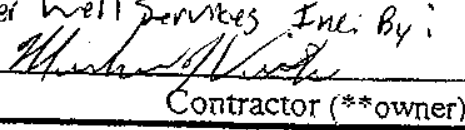

$$
8-|z-1|
$$
Date

* Cwner may sign on wells prior to 7/1/2001 or sandpoint or if well no longer exists and it is unknown when decommissioning occurred 


\section{NOTICE OF WATER WELL DECOMMUSSIONING}

\section{FOR DEPARTMENT UISE ONLY}

Date Filed__ 8/16/11_ Owiner Code No. 60538

O8162011

$$
-\frac{212271}{\text { Well ID }}-\text { Deff }
$$

i. Well Owner's First Name

OR Company Name $\quad \overline{S D A}$

Last Name

Attention Name

Address 1400 independance five S.U Room 4719

ciry washibston state $D_{i} C$ Zip 20250

2. Contractor (if applicable). Webster hell Services Inc

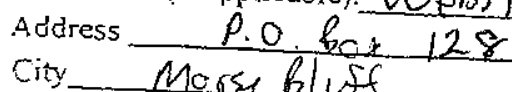

Emaij: wosiQnntene

Telephone Number $\left.\mathrm{H}_{22}\right) 666-9222$ Contractor License No. 39495

Zip Code $68648+$

3a. Weil Registration No. N P A A A

sc. Date Weil Last Operated. LnK

3e. List complete well location: Legal, Footage and/or GPS Coordinates

Weli location: SW $1 / 4$ of the $N E^{1 / 4}$ of Section 16 , Township

The well is feet from the $(N \square$ or $S \square)$ section line and

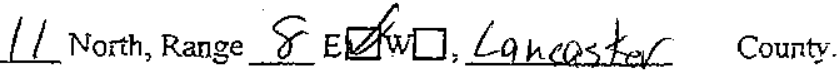
OR L̇atitude Degree:
Longitude Degree:
40
-96 Minute: $\quad 55$ Second: $\frac{30}{28}$ Second: $49 \cdot \frac{59}{59}$

feet ffom the ( $E \square] \square \square$ ) section ine.

3. Location of Water Use:

4. Actual Method for Decommissioning of Well

\begin{tabular}{|c|c|c|}
\hline $\begin{array}{l}\text { Piacennent Depth in Feet } \\
\text { Fiom }\end{array}$ & To & Detailed Description of Material \\
\hline 52 & 6 & Entonte Grout Slume \\
\hline 6 & 5 & concrete con \\
\hline 5 & 0 & Native Soil \\
\hline & & \\
\hline
\end{tabular}

5a. Well Casing Size: $2^{\prime \prime}$

5b. Bore Hole Diameter: unK

I hereby certify that the information provided on this form is true and accurate to the best of my knowledge.

nebster hell Gervices Ine: By

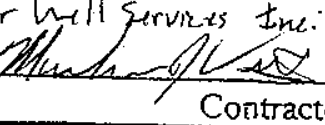
Contractor (**owner)
$8-1211$ Dâie

"Owner may sign on wells prior to 7/1/2001 or sandpoint or if well no longer exjsts and it is unknown when decommissioning occulied

The Department reserves the right to request verification of information provided. 
Submit to:

Department of Natural Resources

301 Centennial Mall South

P.D. Box 94676

Lincoln. Nebraska 68509-4676

Phone (402) 4732363

\section{STATE OF NEBRASKA \\ DEPARTMENT OF NATURAL RESOURCES}

Oct 2007

DNR DECO

\section{NOTICE OF WATER WELL DECOMMISSIONING}

\section{FOR DEPARTMENT USE ONLY}

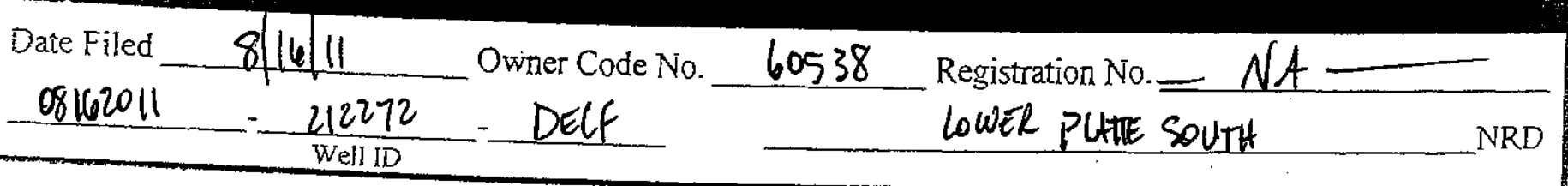

1. Well Owter"s First Name

OR Company Name $\cup S D A$

Last Name

Aftention Name

Address 1400 tndependance Ave Sw Roem 4719

city washingten $\quad$ state $O C \quad$ Zip 20250 Telephone

2. Contractor (if applicable). Wabster hell Services Inc Telephone Number(402666-9222

Address P.O. Box 128

City More Bleff State NE

Emaii: hus sio nutconet

Contractor License No. 39495

This form is required to be filed

within 60 days of decommissigning

of the water well.

3a. Weit Registration No.

32. Purpose of Well:

$$
N / A
$$

Vapor Extaction

ic. Date iveil Last Opeãated. UnK 3d. Date of Decommissioning. $7-|1-1|$

3e. List complete well location: Legal, Footage and/or GPS Coordinates

The well is

e $5 w 1 / 4$ of Section $/ 6$. Township

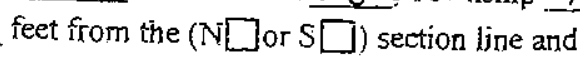

11 North, Range 8 E[G feet from the (E $\square w \square)$ section ine.
OR Latitude Degree:
Longitude Degree:
Minute: $\frac{55}{31}$
Second: 16.59
Second: 56.08

3र. Location of Water Use:

$N / A$

4. Actual Method for Decommissioning of Well

\begin{tabular}{|c|c|c|}
\hline Piacement Depth in Feet & \\
\hline 31 & To & Detailed Description of Material \\
\hline 6 & 6 & Neat Cement qrout Slury \\
\hline 5 & 5 & Concrake Cqp \\
\hline & 0 & Native Ser' \\
\hline & & \\
\hline
\end{tabular}

5a. Well Casing Size:

$2^{11}$

5b. Bore Hole Diameter:

UnK

I hereby certify that the information provided on this form is true and accurate to the best of my knowledge.

hebster indll services Inc. By.

Hhale

Contractor (**owner)

$8-12-11$

Date

* * Owner may sign on wells prior to $7 / 1 / 2001$ or sandpoint or if well no longer exists and it is unknown when decommissioning occurted

The Department reserves the right to request verification of information provided. 


\section{NOTTCE OF WATER WELL DECOMMISSIONING}

This form is required to be filed within 60 days of deconmissioning of the water well.

\section{FOR DEPARTMENT USE ONLY}

Daie Filed $8 / 16111$

Oslezoll

$$
-\frac{212273}{\text { Well ID }}
$$

Owner Code No.

- DECF
Registration No.

i. Weli Owner:s First Name

OR Company Name_L USDA

Last Name

Atiention Name

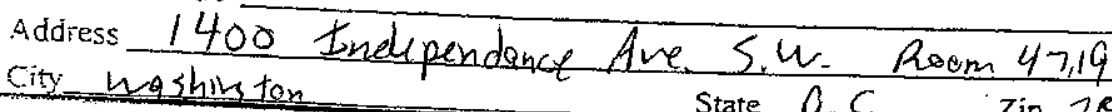
State $0 . C$ Lip 20250

Telephone

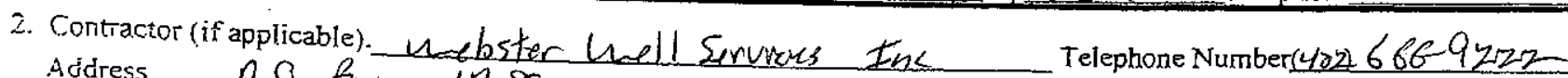

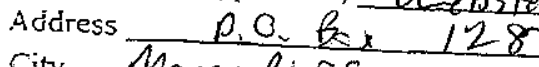
City Mars Binff

Email: hmsi Q unte, nd State $N E$ Contractor License No. 39495

Zip Code 68648

3a. Weil Registrazion No.

36. Purpose of Well:

$$
\frac{N / A}{\text { Vaper Extraction }}
$$

3c. Date Well Last Operated. L L L K

3e. Zist complete well location: Legal, Footage and/or GPS Coordinates

Weli location: $N E^{i / 4}$ of the $5 \mathcal{L}_{1 / 4}$ of Section 16 , Township

The well is

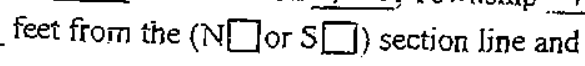

$\begin{array}{rr}\text { OR Latitude Degree: } & 40 \\ \text { Longitude Degree: } & -96 \\ \text { 35. Location of Water Use: } & N / A\end{array}$

Minute: $\frac{55}{31}$ Second: $\frac{16}{54} \cdot \frac{19}{59}$
Minute: 31

\section{Second: 54.59}

4. Actual Method for Decommissioning of Well

\begin{tabular}{|c|c|c|}
\hline Placenent Depth in Feet & & \\
\hline 27 & To & Detailed Description of Material \\
\hline 6 & 6 & Neat Cement Slury \\
\hline 5 & 5 & Natwe Sol \\
\hline & 0 & \\
\hline
\end{tabular}

5a. Well Casing Size:

$2^{11}$

5b. Bore Hole Diameter:

UnK

I hereby certify that the information provided on this form is true and accurate to the best of my knowledge.

nebster hell, servies 先, By:

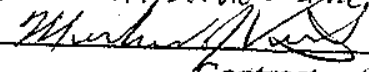
Contractor (**owner)
$8-12 \sim 11$
Date

:Owner may sign on wells prior to 7/1/2001 or sandpoint or if well no longer exists and it is unknown when decommissioning ocentile

The Department reserves the right to request verification of information provided. 


\section{NOTTCE OF WATER WELL DECOMMUSSIONING}

This form is required to be filed within 60) days of deconmissioning of the water well.

\section{FOR DEPARTMENT USE ONLY}

Date Filed $8 \mid 16 / 11$ 08162011 $=\frac{212274}{\text { Well ID }}$ Owner Code No. 60538 Registration No. lowER PutTE SOUTH NRD

1. Weli Owner's First Name

OR Company Name USDA Last Name

Attention Name

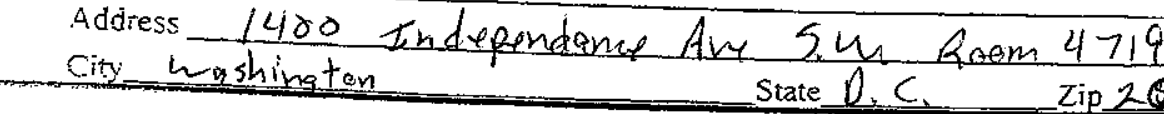
Lip 20250 Telephone

2. Contractor (if applicable). Webster hell Services. Inc Adidress $\mathrm{P} . \mathrm{O} \mathrm{BCx} 128$ Civy Mors Bluff Email:Lusidnutcint Telephone Number( $/ 02866-9222$ Contractor License No. 39495

\section{Well Registration No. $N / A$}

32. Purpose of Weil: Vapor Extraction

3x. Daie Weil Last Operated. UnK Staie $N \in$ Zip Code $68648+$

\section{5e. List complete well location: Legal, Footage and/or GPS Coordinates}

Weli location: NEi/4 of the $5 w / 3$ of Section 16 , Township feet from the (N口or $\overline{S \square}$ ) section line and
$1 /$ North, Range 8 EDJw口, Lancaster County.

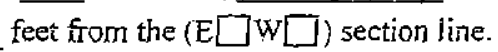
OR Latitude Degree:
40
Longitude Degree:
Minute:
55
Second: 16.59
Minute: Second: $53 \cdot 53$

3. I. Iocation of Water Use: $N, A$

4. Actual Method for Decommissioning of Weil

\begin{tabular}{|c|c|c|}
\hline Piacement Depth in Feet & & \multicolumn{1}{|c|}{ Detailed Description of Material } \\
\hline $3 !$ & 6 & Neat Cement Slurry \\
\hline 6 & 5 & Concmete Cap \\
\hline 5 & 0 & Native So'l \\
\hline & & \\
\hline
\end{tabular}

5a. Well Casing Size: $2^{\prime \prime}$

5b. Bore Hole Diameter: _. $/$ n K

I hereby certify that the information provided on this form is true and accurate to the best of my knowledge.

wibster hell Serviets Inc. By:

Mulact/ und Inc. By. Contractor (**owner) $8-|2-1|$ Date

* * Owner may sign on wells prior to $7 / 1 / 2001$ or sandpoint or if well no longer exists and it is unknown when decommissioning oo BETHEDVD 
Submit to:

Depariment of Natural Resources

¿nl Centergial Malf South

P.O. Box 04676

Lincoln. Nebraska 68509-4676

Phone (402) $471236 j$

\footnotetext{
(
}

ons
Oct 2007

DNR DECO

This form is required to be filed within 60 days of decommissioning of the water weil.

\section{NOTICE OF WATER WELL DECOMMISSIONING}

\section{FOR DEPARTMENT USE ONLY}

Date Filed $8 / 16 / 11$

$08162011-\frac{212275}{\text { Well ID }}-$ DECF Owiner Code No. 60538 Registration No. LOWEL PUTIE SOUTH NRD

1. Well Owner's First Name

OR Company Name USDA

Last Name

Attertion Name

Adiress 1400 Independence Ave Sw Room 4719 City washkgton State $L_{C}$ Lip 20250 Telephone

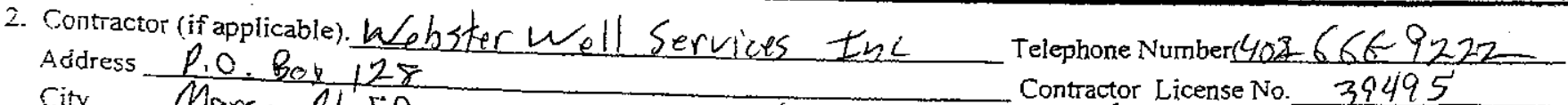

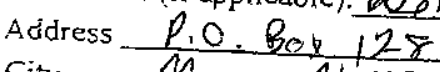
City Morse Bletef

Email: whsionnte not Telephone Number 4026669222
Contractor License No. 39495 Telephone Number 4026669222
Contractor License No. 39495

3z. Weil Registration No.

3. Purpose of Well: State $N F$ Zip Code 68648

3c. Date Weill Last Operated. Napor Extraction

3e. List complete well location: Legal, Footage and/or GPS Coordinates

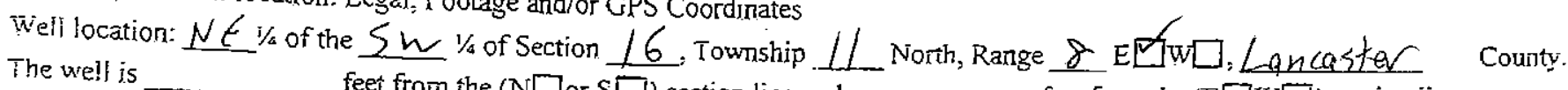

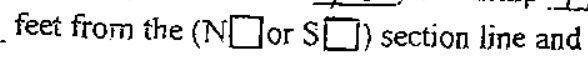

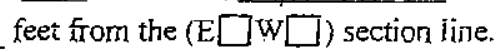
OR Latitude Degree: Longitude Degree. 40 $-96$ Minute: $\quad 55$ Second: 15.23 Second: 53.31 $N / A$

3. Location of Water Use:

4. Actual Method for Decommissioning of Well

\begin{tabular}{|c|c|c|}
\hline Placement Depth in Feet & \multicolumn{2}{|c|}{ Detailed Description of Material } \\
\hline From & To & Neat Cement Slure \\
\hline 6 & 6 & Concrete Cop \\
\hline 5 & 5 & Native Sei \\
\hline & 0 & \\
\hline & & \\
\hline
\end{tabular}

5a. Well Casing Size:

$2^{\prime \prime}$

5b. Bore Hole Diameter:

ink

I hereby certify that the information provided on this form is true and accurate to the best of my knowledge.

hebster hely services Fne. By

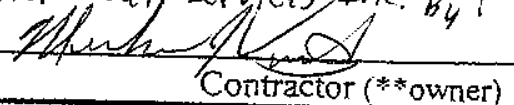

$$
8-12-11
$$


Submit to:

Deparment of Natural Resources

In) Centcnnjal Mall South

P.O. Box 94676

Lincoln. Nebraska 68509-4,676
Phone (402) 47\} 2363

Oct 2007

DNR DECO

STATE OF NEBRASKA
DEPARTMENT OF NATURAL RESOURCES

NOTICE OF WATER WELL DECOMMISSIONING

\section{FOR DEPARTMENT USE ONLY}

Date Filed $8 \longdiv { 1 6 } 1 1$ $-\frac{212276}{\text { Well ID }}$

Owner Code No. $\quad 60538$

Registration No.

LOWER PUTE SOUTH

This form is required in be filed

within 60 days of decommissinning

of the water well.

1. Well Owner's First Name

OR Company Name USDA

Attention Name

Addiess 1400 Independaha Ave Sw Room 4719

City Washnton State DC Zip 20250 Telephone

2. Contractor (if applicable). Webster hell Services Ine Telephone Number(4026669722

Address P.O. Bad 128

City Mors BluFF

Enaii: Lursi a nutcenut

State NE

Contractor License No. 39495

3a. Weil Registration No.

3. Purpose of Well:

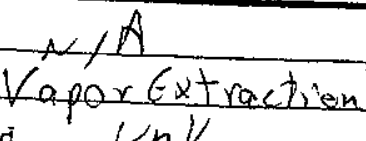

Sc. Date Weil Last Operated.

$\operatorname{lnk}$

3d. Date of Decommissioning.

$2-11-11$

3e. List compleie well location: Legal, Footage and/or GPS Coordinates

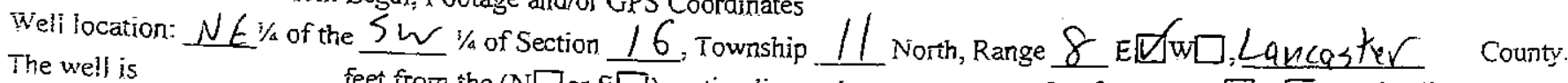
feet from the (N $\square$ or $S \square$ ) section line and

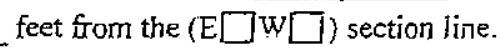
OR Latitude Degree:
Longitude Degree:
40
$-96$
Minute: $\quad 55$
Second: 16.59
Second: 51.01

3ิ. İocation of Water Use: NA

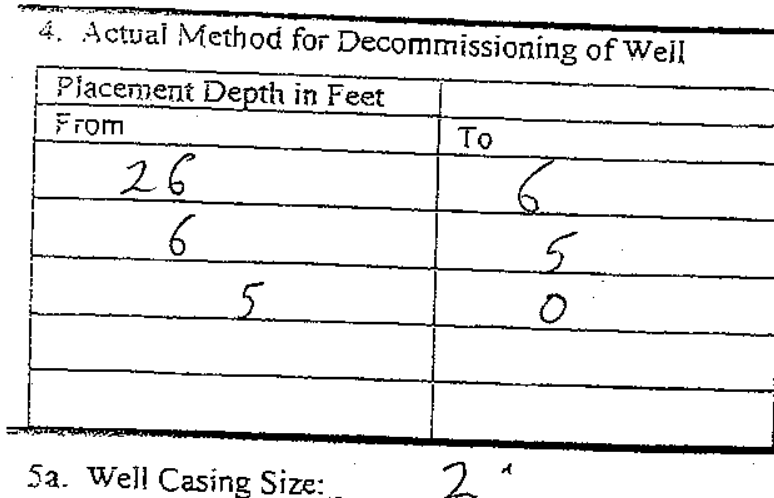

5a. Well Casing Size:

21

5b. Bore Hole Diameter: UnK-

thereby certify that the information provided on this forn is true and accurate to the best of my knowledge.

nebster hely sexvios Inc. Byl

Contractor (**owner)

$8-12-11$ Date

* * Owner may sign on wells prior to 7/1/2001 or sandpoint or if well no longer exists and it is unknown when decommissioning BEE

The Department reserves the right to request verification of information provided. 


Submit to:
Deparment of Naural Resources
3n Centengial Mail South
P.O. Box 0.4676
Lincoln. Nebraska $68509-4676$
Phone (402) 47$\} 2363$

STATE OF NEBRASKA
DEPARTMENT OF NATURAL RESOURCES

\section{NOTICE OF WATER WELL DECOMMUSSIONING}

\section{FOR DEPARTMENT USE ONLY}

Date Filed 8116111

$08162011-\frac{212277}{\text { Well ID }}-$ DECF

Owner Code No. 60538 Registration No. $\quad N A$

1. Well Owner"s First Name

OR Company Name USDA

Last Name

Attention Name

Adiress 1400 Independance Ave Sw Room 4719

Civ hashinton State $10 . C$ Zip 20250 Telephone

2. Contractor (if applicable). hebzter hell Servibes Inc Telephone Number(402660-9222

Address $\frac{P .0 .80 \lambda-128}{12}$

City More Bluff

Emaji: hesi a hntl.neJ

Contractor License No.

Zip Code 68648

39495

32. Weil Registration No._N/A

32. Purpose of Well: Lapar Extraction

3c. Date Weil Last Operated. UNK

5e. List compleie well location: Legal, Footage and/or GPS Coordinates

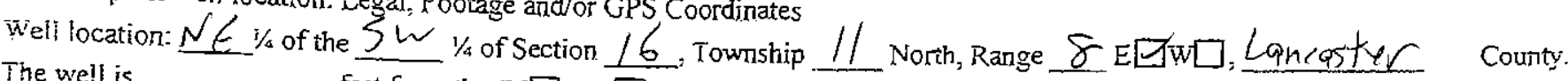

The we!l is feet from the (N口] or $S \square$ ) section line and

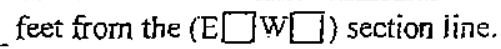
OR Latitude Degree:
Longitude Degree:
40
Q6
Minute: $\quad \frac{55}{31}$
Second: 16.01
Second: 51.4

3. I Iocation of Water Use:

$\sim \angle A$

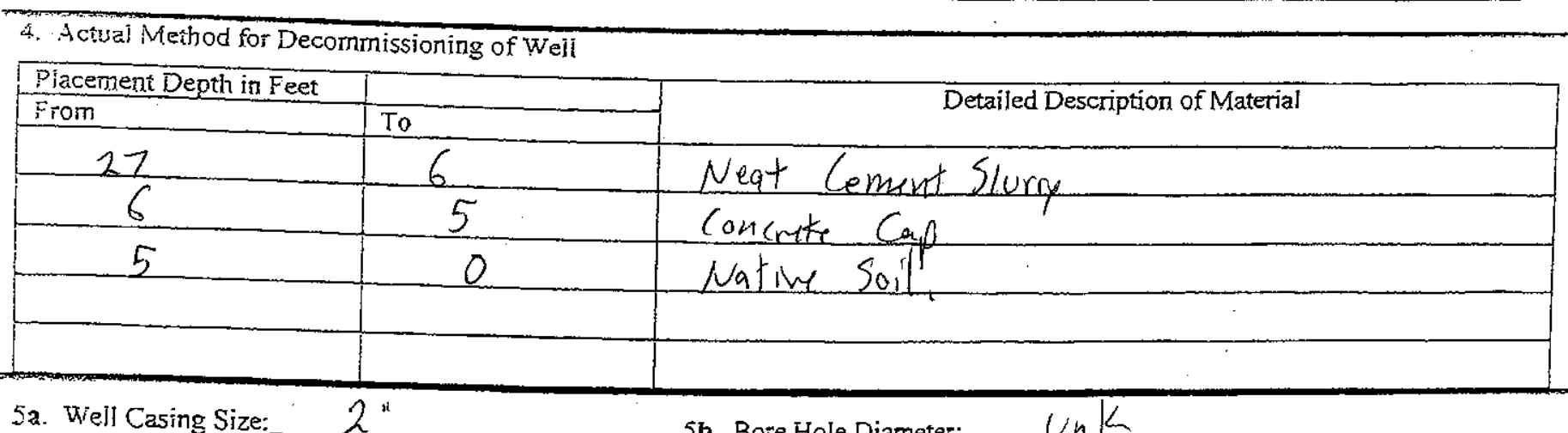

5b. Bore Hole Diameter:

Unk

I hereby certify that the information provided on this form is true and accurate to the best of my knowledge.

webster weh services Int. By.

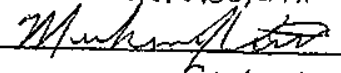
Contractor (**owner)
$8-\mid 2-11$ Date

* * Owner may sign on wells prior to 7/1/2001 or sandpoint or if well no longer exists and it is unknown when decommissioning occured 


\section{NOTICE OF WATER WELL DECOMMUSSIONING}

This form is required to be filed within 60 days of decomrnissioning of the water well.

\section{FOR DEPARTMENT USE ONLY}

Daie Filed 3129112 03292012 $-\frac{216356}{\text { Well ID }}$ Owiner Code No. DEF Registration No. NA

1. Well Owner's First Name

OR Company Name $\cup \overline{S A}$ LOWER PUATE SOUTH NRD

Attention Name

Adiress 1400 Independance Ave S.W Room 4719

city Wajkington State $A . C$ Zip 20250 Telephone

2. Contractor (î applicable). Webster Well Services In Telephone Numbert(10z 666-9222 Ađiress P.a box 128 Email:uwsignatcinet Contractor License No. 39495 Last Name

3a. Weil Registration No. $N / A$

39. Purpose of Well: Vapar Extraction

ic. Date Weil Last Operated. Un K

3e. List complete well location: Legal, Footage and/or GPS Coordinates

veli iocation: $N E$ i/4 of the SW $1 / 4$ of Section $/ 6$. Township

The we! is feet from the (N $\square$ or $S \square$ ) section line and

Nonth, Range 8 EDWD, Lancoster County. Zip Code $68648+$
OK Latitude Degree: $\quad 40$ Longitude Degree Minute: 55
$-96$ Minute: Second: 15.59 Second: 53.00 feet from the ( $E[\square W \square$ ) section inte.

Tิ. Iocation of Water Use:

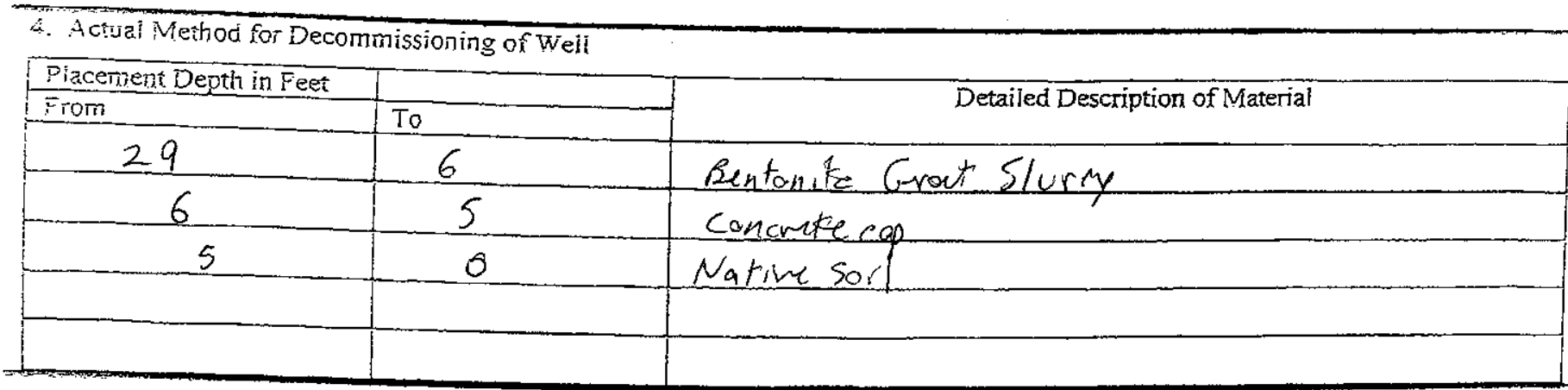

5a. Well Casing Size: 2

5b. Bore Hole Diameter:

unk

Thereby certify that the information provided on this form is true and accurate to the best of my knowledge.

mebster hell servirgatucBy:

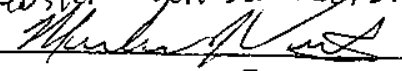

Contractor (**owner)

$$
8-12-11
$$

Daie

$\because$ Owner may sign on wells prior to $7 / 1 / 2001$ or sandpoint or if well no longer exists and it is unknown when decormmissioning occurted 


\section{NOTICE OF WATER WELL DECOMAMSSIONING}

This form is required to be filled within 60 days of decommissioning of the water well.

\section{FOR DEPARTMENT USE ONLY}

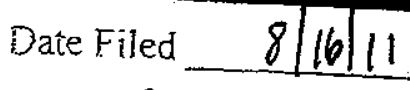

08162011 $-\frac{212278}{\text { WeIl ID }}$

Owner Code No.

DECF
Registration No. LOWEL PlattE SOUTH

1. Well Owner's First Name

OR Company Name USDA Last Name

Attention Name

Address 1400 Civ hashmenton Independance Ave S.w Room 4719 State $D<$ Zip 20250 Telephone

2. Coritractor (if applicable). hebster hell Servizes Inc Adidress p.O Boy 128 City Marse Bluff Emais: wasionnte,net

32. Well Registration No.

30. Purpose of Weil: State $N E$ Zip Code $68648+$

is. Date Well Last Operated. U U K 3d. Date of Decommissioning. $7-11-11$

5. List compleie well location: Legal, Footage and/or GPS Coordinates

Weli location: $N E_{1 / 4}$ of the SL $1 / 4$ of Section 16 , Township The we!l is feet from the (N口or $S \square$ ) section line and
11 North, Range 8 EVW $\square$, Lancaster County.

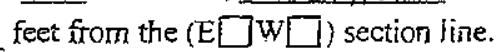
OR Latitude Degree: Longitude Degree: Minute: 55 Minute: -31 Second: 15.59 Second: 54.03 $-40$

3r. tocation of Water Use: $N / A$

4. Actual Method for Decommissioning of Well

\begin{tabular}{|c|c|c|}
\hline Piacenent Depth in Feet & & \\
\hline 21 & To & Detailed Description of Material \\
\hline 6 & 6 & Neat Cement Slurry \\
\hline 5 & 5 & Native Soi \\
\hline & 0 & \\
\hline & & \\
\hline
\end{tabular}

5a. Weil Casing Size: $2^{\prime \prime}$

5b. Bore Hole Diameter: Un $/<$

inereby certify that the information provided on this form is true and accurate to the best of my knowledge.

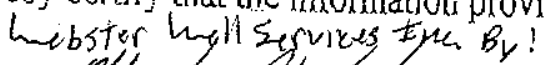

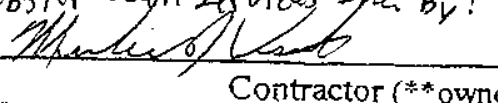$$
8-1211
$$
Date

* * Ownei may sign on wells prior to $7 / 1 / 2001$ or sandpoint or if well no ionger exists and it is unknown when decommissioning occured 


\section{NOTICE OF WATER WELL DECOMMISSIONING}

This form is required to be filed within 60 days of decommissioning of the water well.

\section{FOR DEPARTMENT USE ONLY}

Date Filed $8 / 16 / 11$
O81620U $-\frac{212279}{\text { Well ID }}-$ DECf

1. Well Owner"s First Name

OR Company Name USDA Last Name

Attention Name

Addiess 1400 Independance Ave SW Room 4719

City hashihaten State D.C Zip 20250 Telephone

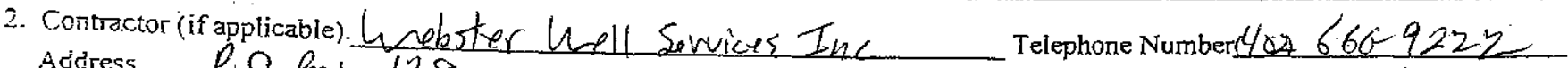
Adiress Pio fot 128 City Marse Bluff

Email: lavsignetcinet Contractor License No. 39495

32. Weir Registration No.

3. Purpose of Weil:

$$
\text { Vapar Gxtraction }
$$

3c. Date Well Last Operated. $\bigcup n K$ 3d. Date of Decommissioning. $7-1|-1|$

\section{3e. List complete well location: Legal, Footage and/or GPS Coordinates}

Weli location: $N E^{1 / 4}$ of the $S W / 1 / 4$ of Section /6. Township

The well is feet from the (N口] or $\mathrm{S \square}$ ) section line and

\section{North, Range 8 EVw $\square$, Lancoster County.}

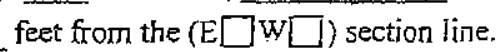
OR Latitude Degree: 40
Longitude Degree: -96
Minute: $\quad 55$
Second: 15.59 Second: 55.37

3. Location of Water Use:____ N/A

\section{Actual Method for Decommissioning of Well}

\begin{tabular}{|c|c|c|}
\hline Piacement Depth in Feet & & \\
\hline From & To & Detailed Description of Material \\
\hline 18 & 6 & Neaf Censet Slurry \\
\hline 6 & 5 & Conevele Cof \\
\hline 5 & 0 & Native Sel \\
\hline & & \\
\hline & & \\
\hline
\end{tabular}

5a. Well Casing Size:

$2^{\prime \prime}$

5b. Bore Hole Diameter:__un $K$

I hereby certify that the information provided on this form is true and accurate to the best of my knowiedge.

hebster hen Servives Inc. By:

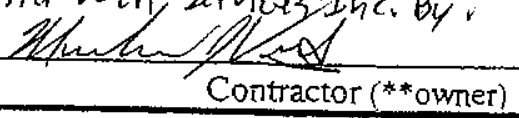

$$
5-12-1 \mid
$$
Date

* * Owner may sign on wells prior to 7/1/2001 or sandpoint or if well no longer exists and it is unknown when decommissioning obeefFEVVED 
Submit to:

Department of Natural Resources

301 Cenicinial Mail South

P.0. Box 94676

Eincoln. Nebraska 68509-4676

Prone (402) 4712363

STATE OF NEBRASKA

DEPARTMENT OF NATURAL RESOURCES

Oct 2007

DNR DECO

NOTICE OF WATER WELL DECOMMISSIONING

\section{FOR DEPARTMENT USE ONLY}

Daie Filed $8116 / 11$ 0816201 $-\frac{212280}{\text { Well ID }}$ Owner Code No.

DÉCF Registration No. $\sqrt{A-}$

This form is required to be fifled within 60 days of decornmissioning of the water well.

1. Well Owner"s First Name

OR Company Name USDA

Attention Name

Addiess 1400 Independance Ave Su Ream 4719

city washington State $D . C$ Zip 20250 Telephone

2. Contiactor (if applicable). Webster hall Sevvicys. Inc. Telephone Number(40) 6668222 Address $\quad$ D. O Box 128 City Merse Bluff Enaii: whsiontic net Last Name

3a. Weil Registration No.

32. Purpose of Weil: Vapar Extraction

3r. Date Well Last Operated. unk 3d. Date of Decommissioning. $7-1 / 11$ Contractor License No. 39495

3. List complete well location: Legal, Footage and/or GPS Coordinates

Well location: $N E^{i / 4}$ of the SW $1 / 4$ of Section 16 . Township. The well is feet from the (N口 $\square$ or $\mathrm{S} \square$ ) section line and North, Range 8 EUw口, Lancaster county.
OR Latitude Degree: $\quad 40$ Longitude Degree: Misute: 55 Second: 15.59 Minute: second: 57.03

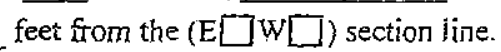

31. Incation of Water Use:

4. Actual Method for Decommissioning of Well

\begin{tabular}{|c|c|c|}
\hline $\begin{array}{l}\text { Placentent Depth in Feet } \\
\text { From }\end{array}$ & To & Detailed Description of Material \\
\hline 11 & 6 & Neat cement slurm \\
\hline 6 & $S$ & conevite cap \\
\hline 5 & $\theta$ & Natue Sol \\
\hline & & 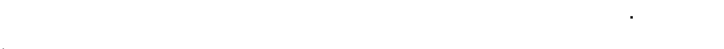 \\
\hline
\end{tabular}

5a. Well Casing Size:

$2^{\prime \prime}$

5b. Bore Hole Diameter:

$\ln K$

I hereby certify that the information provided on this form is true and accurate to the best of my knowledge.

nebster mell servigss tan By.

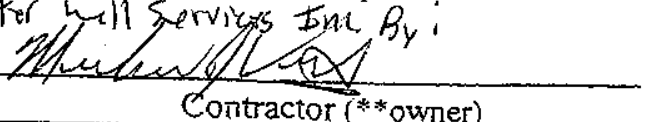

$$
8-12-11
$$
Contractor (**owner) Date

* Owner may sign on wells prior to $7 / 1 / 2001$ or sandpoint or if well no longer exists and it is unknown when decommissioning occurece 


\section{NOTICE OF WATER WELL DECOMMISSIONING}
STATE OF NEBRASKA
DEPARTMENT OF NATURAL RESOURCES
This form is required to be filed within 60 days of deconmissioning of the water well.

\section{FOR DEPARTMENT UUSE ONLY}

Daîe Filed $8[16] 11$ 08162011 $-\frac{212281}{\text { WeII ID }}$ Registration No.

60538 DECF

1. Well Owner's First Name

OR Company Name USDA Last Name

Attertion Name

Address 1400 Independance Ave S.W Room 4719

City washington state D.C. Zip 20250 Telephone

2. Contractor (if applicable). Webster hell Services Inc. Address P. O. Bol 128 City Merse BluFf Emaii: hrsionaternet

3a. Weil Registrasion No.

36. Purpose of Weil: Vapor $E$
3c. Date Well Last Operated. $U H L$ Stâie $N E$ Zip Code $68048+$ 3d. Date of Decommissioning.

3e. List complete well location: Legal, Footage and/or GPS Coordinates

Well location: $N E_{i} / 4$ of the SW 1/4 of Section 16 , Township

The well is feet from the (N口or $S \square$ ) section line and

$1 /$ North, Range \& E W W L Lancaster County.
OR Latitude Degree:
40
Longitude Degree: -96 Minute: 55
Second: 15.03 Second: $55 \cdot 03$ feet from the (E $\square W \square$ ) section Iine.

3. Location of Water Use:

$\sim / A$

\begin{tabular}{|c|c|c|}
\hline $\begin{array}{l}\text { Placennent Depth in Feet } \\
\text { Fiom }\end{array}$ & $T$ & Detailed Description of Material \\
\hline 17 & 6 & Neat Cement Slurm \\
\hline 6 & 5 & Conevete Cap \\
\hline 5 & 0 & Natius Soll \\
\hline & & \\
\hline 5a. Well Casing Size: & $2^{\prime \prime}$ & 5b. Bore Hole Diameter: $v_{n} K$ \\
\hline
\end{tabular}

I hereby certify that the information provided on this form is true and accurate to the best of my knowledge.

hebster uellyservives, Ine Bu.

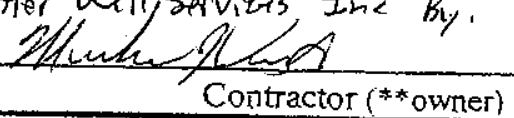

$$
8-12-1 \mid
$$




\section{STATE OF NEBRASKA DEPARTMENT OF NATURAL RESOURCES \\ This form is required to be filed within 60 days of decommissioning of the water well.}

\section{NOTICE OF WATER WELL DECOMMISSIONING}

\section{FOR DEPARTMENT USE ONLY}

Daie Filed__ $8 \mid 16 / 11$ 08162011

$$
-\frac{212282}{\text { Well ID }}
$$

Owner Code No.

Decf
60538

Registration No. -NA -

i. Well Owner's First Name

OR Company Name U USDA Last Name

Attertion Name

4diess 1400 Independince Ave SW Room 4719

city washington State $0, C$. Zip 20258 Telephone

2. Contractor (if applicable). Webster hell Lervers Inc Adidress P.Q Bot 128 City Marse Bluff Email: whi, onntc.net

Telephone Number 403669922 Contractor License No. 39495

32. Weil Registration No.

32. Purpose of Wejt: State $N G$ LOWER iLATIE SOUTH NRD

3. Date wieil Vapor Extraction

ac. Un K

3x. List complete well location: Legal, Footage and/or GPS Coordinates

3d. Date of Decommissioning. $7-11-1$

Well location: $N \in \overline{1} / 4$ of the SL $1 / 4$ of Section 16 , Township

The we!l is feet from the (ND or $S \square$ ) section line and

11 North, Range 8 E tw口, Lancaster County.
OR Latitude Degree: Longitude Degree: Minute: $\frac{55}{31}$ Second: 15.03

$\frac{40}{-96}$ Second: 53.42

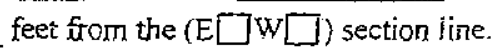

3f. Iocation of Water Use:

4. Actual Method for Decommissioning of Well

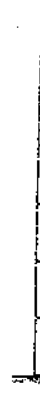

\begin{tabular}{|c|c|}
\hline Placenent Depth in Feet & \\
\hline From & To \\
\hline 16 & 6 \\
\hline 6 & 5 \\
\hline 5 & 0 \\
\hline & \\
\hline & \\
\hline
\end{tabular}

5a. Wiell Casing Size: $2^{11}$

5b. Bore Hole Diameter: Detailed Description of Material

I hereby certify that the information provided on this form is true and accurate to the best of my knowledge.

nebster hell, Servives Inc. By: $\frac{\text { Hewator }}{\text { Contractor (**owner) }}$ $8-1211$ Date $\because$ OWner may sign on wells prior to $7 / 1 / 2001$ or sandpoint or if well no longer exists and it is unknown when decommissioning occutred 


\author{
STATE OF NEBRASKA \\ DEPARTMENT OF NATURAL RESOURCES
}

NOTICE OF WATER WELL DECOMMUSSIONING

\section{FOR DEPARTMENT USE ONLY}

Owner Code No. $\quad 60538$ $-\frac{212283}{\text { Well ID }}-$ DECF

Registration No. $-N A$ LOWER PGITE SOUTH
Oct 2007

DNR DECO

This form is required to be filed within 60 days of deconmissionning of the water well.

Date Filed $8 / 16 / 11$

08162011 Last Name

I. Well Owner's First Name

OR Company Name_L $\quad$ _S $D A$

Attention Name

Address 1400 tndependame fine 5 w Room 4719

Cive Whashom State D.C. Zip 20250 Telephone

2. Contractor (if applicable). Webster hall Services Inc Adaress P.Q $\mathrm{Bat} 12 \mathrm{x}$ City Mers Bluff Emaii: hensionut, nd Telephone Numberifos 6669222 Contractor License No. 39495 Zip Code $68648+$

3a. Well Registration No

32. Purpose of Well: $M / A$ Vapar Extraction

3c. Date Well Last Operated. UnK 3d. Date of Decommissioning. $7-11-11$

je. List complete well location: Legal, Footage and/or GPS Coordinates

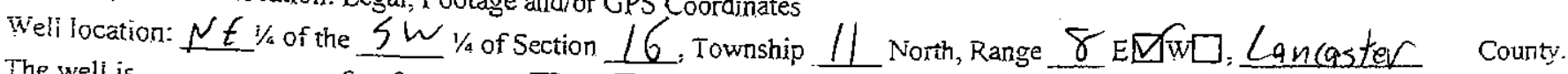

The we!l is feet from the (ND] $S \square$ ) section line and feet from the (E$\square w \square)$ section ine. OR Latitude Degree:
Longitude Degree: $\quad-40$

3. Location of Water Use: Minute: $\frac{55}{31}$ Second: $\frac{15}{52} \cdot \frac{83}{13}$

\footnotetext{
4. Actual Method for Decommissioning of Well
}

\section{Placement Depth in Feet} From

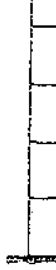

5a. Weill Casing Size:

$N / A$ NRD 
STATE OF NEBRASKA

DEPARTMENT OF NATURAL RESOURCES
Oct 2007

DNR DECO

This form is requited to be filed within 60 days of decommissioning of the water well.

\section{NOTICE OF WATER WELL DECOMMISSIONING}

\section{FOR DEPARTMENT USE ONLY}

Date Filed 8$] 16 / 11$ 08162011

$$
=\frac{212284}{\text { WelliD }}-\text { DECF }
$$

Owiner Code No. 60538

Registration No.

i. Well Owner:s First Name

OR Company Name

Attention Name

Adjress 1400

Ende pendance

city hajhmaton tependance. Hive sh hoom 4719 LOWER

NA $\longrightarrow$

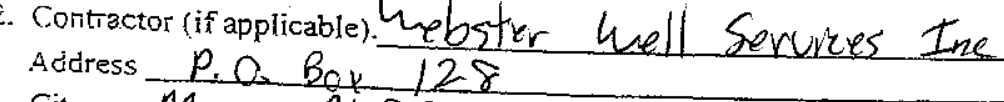
City Morse Bluff Email:Lwsionnte.nat

32. Weil Registration No.

3. Purpose of Weil:

N/A

2x. Dase Weil Last Operated. UnK 3d. Date of Decommissioning. $7 \sim 11 \sim 11$

3e. List complete well location: Legal, Footage and/or GPS Coordinates

Wieli location: $N E^{i / 4}$ of the SW $1 / 4$ of Section /6, Township

The well is feet from the (N口 $\square$ or 5 ) section line and
$1 /$ North, Range \& EEwD. Lahcastor County.

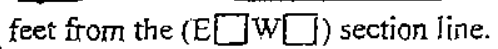
OR Latitude Degree: Longitude Degree
40 $-96$ Minute: $\quad 55$ Second: $/ 5.03$ Second: 51.03

3र. Location of Water Use: N/A

\footnotetext{
4. Actual Method for Decommissioning of Weil
}

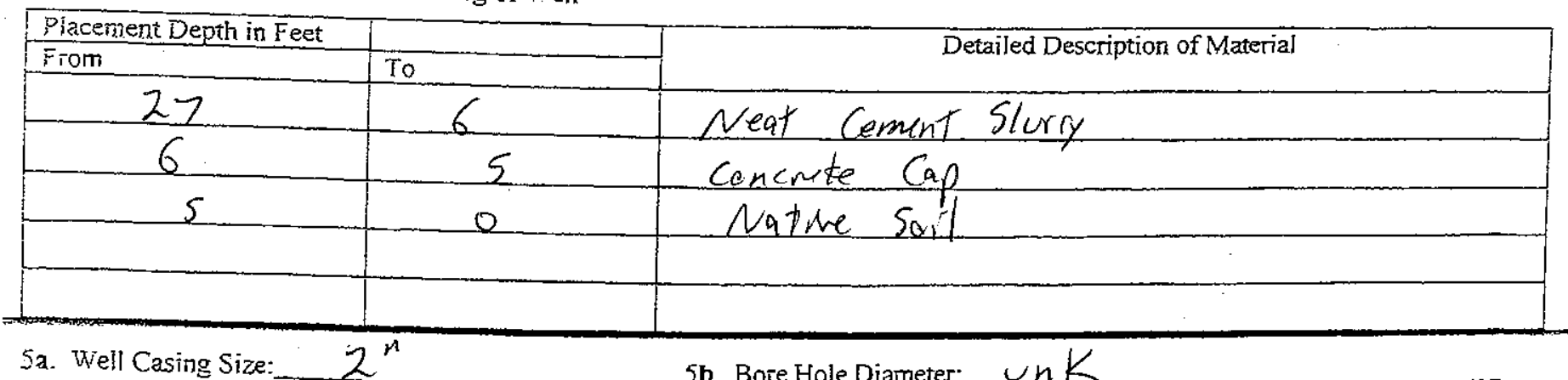

inereby certify that the information provided on this form is true and accurate to the best of my knowledge.

nebsfer uell services tine by ?

Houla

$8-|2-1|$

*: *Owner may sign on wells prior to $7 / 1 / 2001$ or sandpoint or if well no longer exists and it is unknown when decommissioning occurted Date 


\section{Submit to:}

Department of Natural Resources

301 Centonnial Mall South

P.0. Box 0.4676

Eincoln. Nebraska 68509-4676

Phone $(402) 4712363$
STATE OF NEBRASKA
DEPARTMENT OF NATURAL RESOURCES

Oct 2007

DNR DECO

This form is required to be filed within 60 days of decornmissioning of the water well.

\section{NOTICE OF WATER WELL DECOMMISSIONING}

\section{FOR DEPARTMENT USE ONLY}

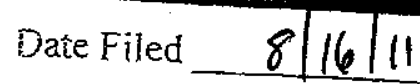
08162011
Owner Code No.

DEF
60538 Registration No. Loarel PLATEE SOUTH NRD

1. Well Owner"s First Name

QR Company Name $\operatorname{USDA}$ Last Name

Attention Name

Address 1400 Independaned twe Sw. Room 4719 City washnaton State $R_{2}$ in 20250 Telephone

2. Contractor (if applicable). Webster weh Servieres Ind Telephone Number(402666 92z2

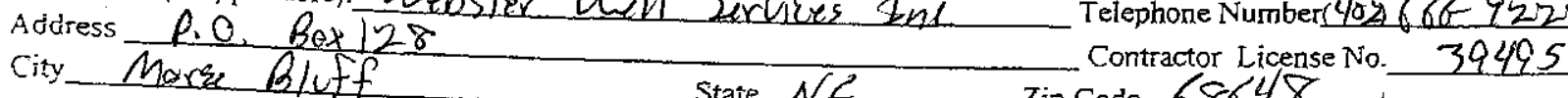
Email: Lurs/Q nntcrhet Zip Code 68648

3r. Weil Registration No.

3. Purpose of Well: $\alpha / 1$

3c. Date Well Last Operated. UnK 3d. Date of Decommissioning. $7-15-11$

2e. List complete well location: Legal, Footage and/or GPS Coordinates

Weli location: $N E^{1 / 4}$ of the $S W$ 1/4 of Section /6, Township

The well is feet from the (ND] or $S \square$ ) section line and
$1 /$ North, Range 8 E[VWD, Lancasten County. feet from the (E[ $\square w \square$ ) section line.

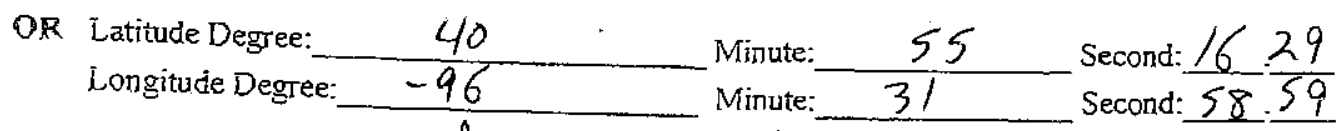

3. Location of Water Use:

$N / A$

4. Actual Method for Decommissioning of Well

\begin{tabular}{|c|c|c|}
\hline Placement Depth in Feet & & \\
\hline From & To & Detailed Description of Material \\
\hline 20 & 6 & Neat Cement Slurry \\
\hline 6 & 5 & Concrete Cap \\
\hline 5 & 6 & Natihe Sor \\
\hline & & \\
\hline
\end{tabular}

5a. Well Casing Size: $2^{n}$

5b. Bore Hole Diameter: $\cup_{n} K$

thereby certify that the infonmation provided on this form is true and accurate to the best of my knowledge.

ubstir helysenzes tye By.

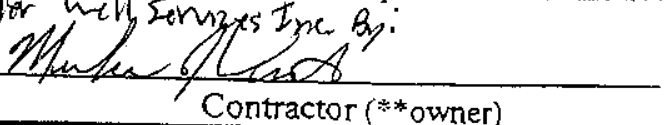

$8-12-11$ 


\section{NOTICE OF WATER WELL DECOMAMISSIONING}

\section{FOR DEPARTMENT USE ONLY}

Date Filed $8116 / 11$ 08162011 $-\frac{212286}{\text { Well ID }}$ Owner Code No. 60538 DECE Registration No. LOWER PUATE SOUTH $N R D$

I. Well Owner's First Name

OR Company Name $U S D A$ Last Name

Attention Name

Address 1420 city washington independance Ave Sur Room 4719

2. Coritiactor (if applicable). Luebster well Servies Ine Address $P . Q B_{20}-128$ City Mors Bluff Email:unsi@unterne Lip 20250 Telephone

This form is required to be filed within 60 days of deconmissioning of the water well.

32. Weil Registration No. N/A

36. Purpose of Well:_L_Lapor Extraction

3c. Date Well Last Operated. UnK 3d. Date of Decommissioning. $\quad 7-11-11$

3x. List complete well location: Legal, Footage and/or GPS Coordinates

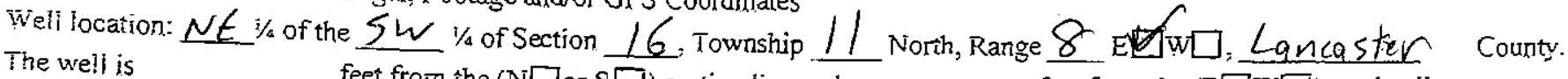
feet from the (N $\square$ or $S \square$ ) section line and

Telephone Number 4 (r2) 666 Q222 Contractor License No. Zip Code 68648 39495
OR Latitude Degree: Longitude Degree:
40 Minute: 55 Minute: Second: 14.40 Second: 58.40

3f. Location of Water Use: $N / A$

4. Actual Method for Decommissioning of Well

\begin{tabular}{|c|c|c|}
\hline Placenent Depth in Feet & & Detailed Description of Material \\
\hline From & To & Neat Cement Slumy \\
\hline 6 & 6 & concrek Cap \\
\hline 5 & 5 & Natihe Sor \\
\hline & 0 & \\
\hline
\end{tabular}

5a. Well Casing Size:

$2^{\mu}$

Sb. Bore Hole Diameter:

Un $K$

I hereby certify that the information provided on this form is true and accurate to the best of my knowledge.

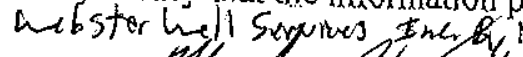

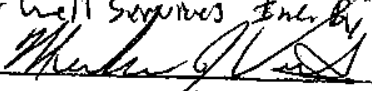

Contractor (**owner)
$8-12-11$ Date

$\therefore$ *Owner may sign on wells prior to 7/1/2001 or sandpoint or if well no longer exists and it is unknown when decommissioning occhECEEVED 


\section{STATE OF NEBRASKA DEPARTMENT OF NATURAL RESOURCES}

DNR DECO

This form is required to be filed within 60 days of decommissioning of the water well.

\section{NOTICE OF WATER WELL DECOMAMUSSIONING}

\section{FOR DEPARTMENT USE ONLY}

Date Filed 8/16]11 $08162011-212281$
Owner Code No.

DECF
60538 Registration No. LOWER JLATE COUTH

i. Weli Owner's First Name

OR Company Name

Attention Name

Address 1400 Inde pendance Ave SW Room 4719

City Washmiton State D.C. Zip 20250 Telephone

2. Contractor (if applicable). Webstor well Servives the Adidress PQ hat $\frac{128}{128}$ City Mors Bluff Emaii: Lw Sionntlind

3a. Weil Registration No.

i. Purpose of Well:

3x. Date Well Last Operated. Vaper Extraction 3d. Date of Decommissioning. $7-11-11$

\section{3c. List complete well location: Legali, Footage and/or GPS Coordinates}

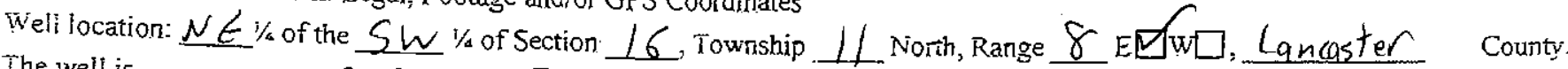
The we!l is feet from the (N口 or $S \square$ ) section line and feet from the (E$\square W \square$ ) section line.
OR Latitude Degree: $\quad 40$ Longitude Degree: $\sim 96$ Minute: $\quad 55$ Minute: 31 Second: 14.41 Second: 57.04

\section{3̂. tocation of Water Use: _ N N/A}

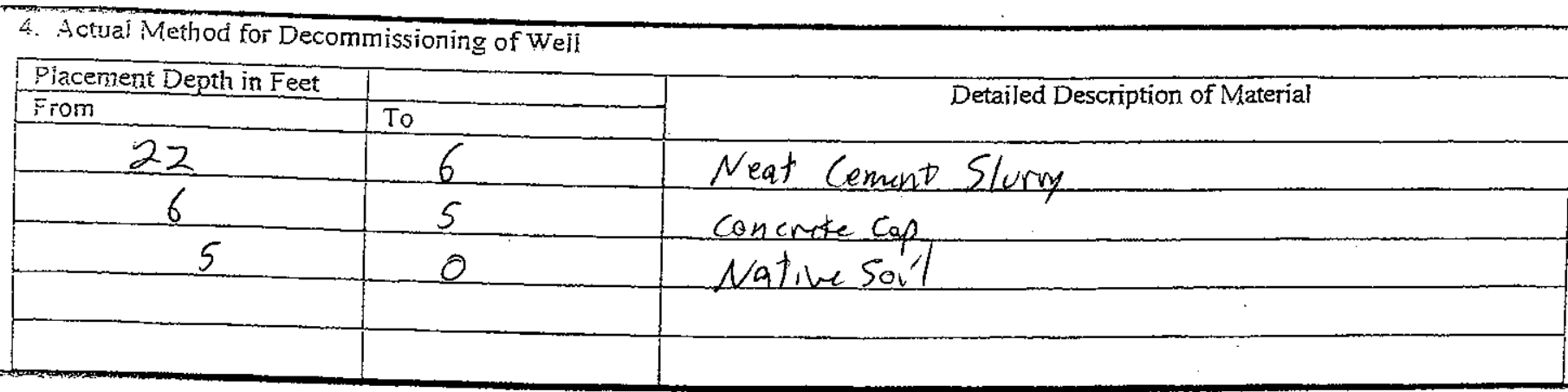

5a. Wiell Casing Size: $22^{n}$

Sb. Bore Hole Diameter: Uh $\mathrm{K}$

I hereby certify that the information provided on this form is true and accurate to the best of my knowledge.

hebstor hellyerviesim By:

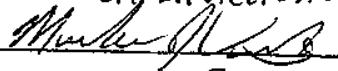




Submit to:
Department of Natural Resources
301 Centconial Mall South
P.O. Box 04676
Lincoln. Nebraska $68509-4676$
Phone (402) 47J 2363

STATE OF NEBRASKA
DEPARTMENT OF NATURAL RESOURCES

NOTICE OF WATER WELL DECOMMUSSIONING

\section{FOR DEPARTMENT USE ONLY}

Daie Filed $8 / 6) 11$ 08162011
Owiner Code No.

- DECF
60538
Registration No. $N k$. LOWER PLtTE SOUTH
This form is required to be filed within 60 days of decommissioning of the water well.

1. Weli Owner"s First Name

OR Company Name $\cup S D A$

Last Name

Attention Name

Adiress 1400

ciry washiston

Independane

(2)

Last Name 2. Contractor (if applicable). Webster hell sorwes Ine City Morse Bllff Emait: whs! o nutc neT State $\mathbb{N}$ Ave Sw Room 4719

3a. Weit Registration No. N/A

3c. Purpose of Well:_ Soll Gas Menitonig

3c. Date Weil Last Operated. Unk 3d. Date of Decommissioning. $\quad 7 \sim 11-1$

Telephone Numbertirz 6669222 Contractor License No. 39495

3c. List complete well location: Legal, Footage and/or GPS Goordinates

Well location: $N t^{i / 4}$ of the $5 \mathrm{~W}$ \% of Section $/ 6$, Township.
The well is feet from the (NDor $S \square$ ) section line and
$1 /$ North, Range \&EVWL, Lancaster County. feet from the ( $E \square W \square)$ section line.
OR Latitude Degree:
Longitude Degree:
40
Minute: $\frac{55}{3 /}$
second: 1601
Second: $58 \cdot 40$

3f. I,ocation of Water Use:

, $A$

4. Actual Method for Decommissioning of Weil

\begin{tabular}{|c|c|c|}
\hline Piacement Depth in Feet & & \\
\hline 18 & To & Detailed Description of Material \\
\hline 6 & 6 & Neat Cemant Slurry \\
\hline 5 & 5 & Concrete Conp \\
\hline & 0 & Natne Sor \\
\hline & & \\
\hline
\end{tabular}

5a. Weill Casing Size:

$1^{r}$

Sb. Bore Hole Diameter:

unk

Thereby certify that the information provided on this form is true and accurate to the best of my knowledge.

uebster hyeh servesy sne. Byi

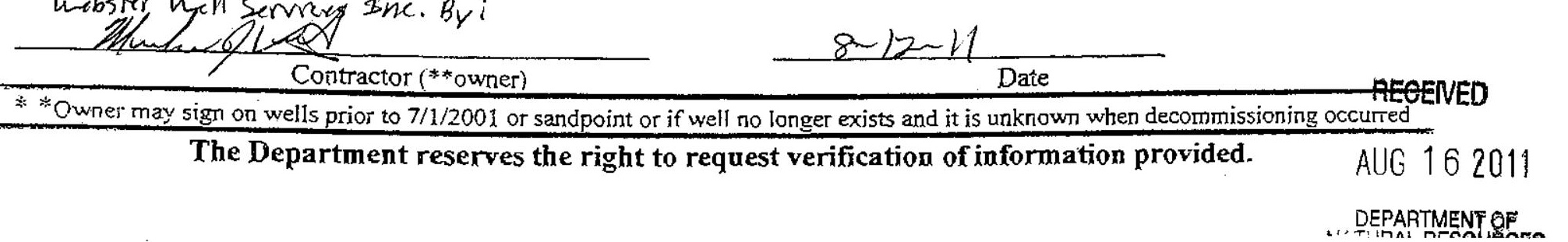




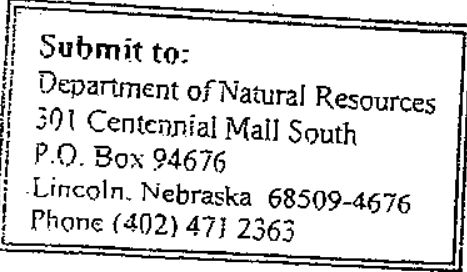

STATE OF NEBRASKA
DEPARTMENT OF NATURAL RESOURCES

NOTICE OF WATER WELL DECOMMISSIONING

Daie Filed $8 / 16 / 11$ 08162011. $-\frac{212289}{\text { Well ID }}$ Owiner Code No. $\quad 60538$ Registration No. DECF LOWER PLTTE SOUTH NRD

i. Well Owner's First Name

SR Company Name USOA

Last Name

Aitention Name

Adjiess 1400 Independence Ale Sw Room 4719

City washingten $\quad$ State D.C. Zip 20250 Telephone

2. Contiactor (if applicable). We boter hell Servies the Telephone Number(4026669222 Adidess P.Q. Bex 128

City Morse BLff

Email: husionite ne

3a. Weil Registration No. N/A

3. Purpose of Weil: Sol Gas Monltorling

3c. Date Weil Last Operated. $U$ L $L$

je. List complete well location: Legal, Footage and/or GPS Coordinates

weli location: $N t^{i / 4}$ of the $S W 1 / 4$ of Section $/ 6$. Township

The well is feet from the (NDor S $\square$ ) section line and

Zip Code 68648

State NE $+$
OR Latitude Degree: $\quad-40$
Longitude Degree: $-\frac{-96}{}$ Minute: $\frac{55}{31}$ Second: 16.25 Second: $55 \cdot 46$

3f. Location of Water Use:

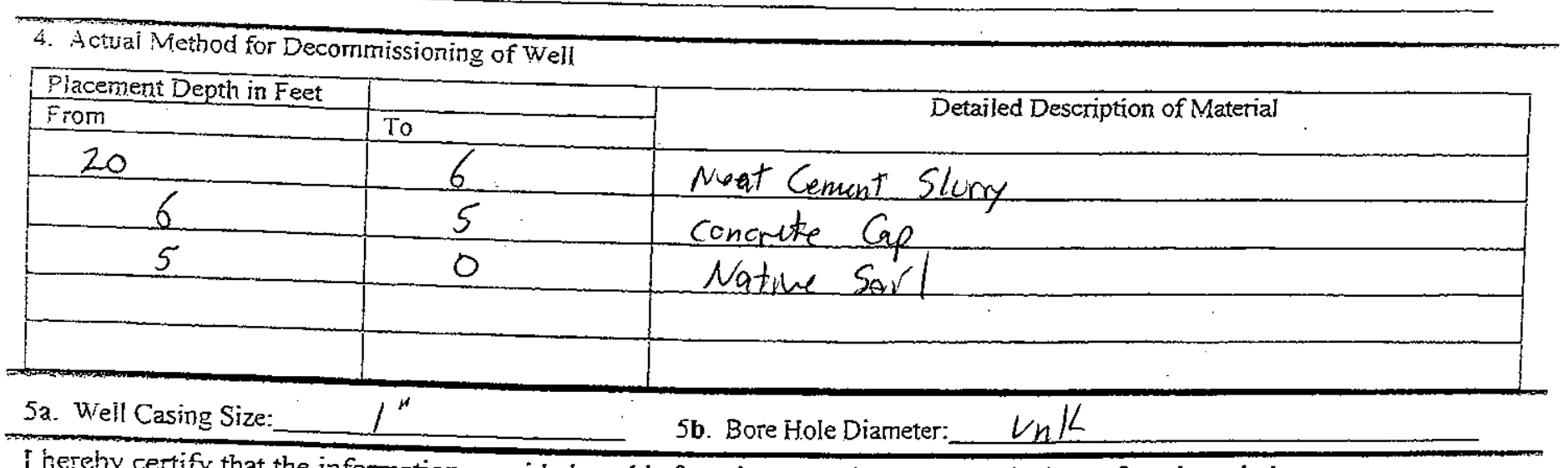

thereby certify that the information provided on this form is true and accurate to the best of my knowledge.

Hebster hell Serviges Inc. By Contractor (**owner)
$8-12-11$ Date 
Submit to:

Department of Natural Resources

301 Centengial Mall South

P.O. Box 04676

. Liлcoln. Nebraska 68509-4676

Phore (402) 471 2363
STATE OF NEBRASKA

DEPARTMENT OF NATURAL RESOURCES
Oct 2007

DNR DECO

This form is required to be filed within 60 days of decommissioning of the water weil.

\section{NOTICE OF WATER WELL DECOMMMSSIONING}

\section{FOR DEPARTMENT USE ONLY}

Date Filed 811611 08162011

$$
-\frac{212290}{\text { Well ID }}
$$

Owner Code No.

DECF
60538 Registration No. LOWER PWATE SOUTH

i. Weli Owner's First Name

OR Company Name USDA

Attention Name

Addiess 1400 Independence Ave sw heom 4719

city hashingtion State D.C. Zip 20250 Telephone

2. Contractor (if applicable). Webster hell Senvers Bhe Address $P 0_{*} \mathrm{Bap} 128$ City Marse Bleff Enail:wusiantatenep Last Name

3z. Weil Registration No

36. Purpose of Weil:

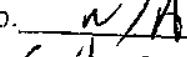
Soll Gas Monitoring

3c. Date Weil Last Operated. UnK State $N G$

Telephone Number( $402866-9222$ Contractor License No. 39495

3e. List complete well location: Legal, Footage and/or GPS Coordinates

Theli location:
The well is $5 \mathrm{~L} 1 / 4$ of Section 16 , Township. feet from the (ND $\square$ or $S \square$ ) section line and Zip Code 68648 $+$

The well is

$$
\begin{array}{rr}
\text { OR Latitude Degree: } & 40 \\
& \text { Longitude Degree: }
\end{array}
$$
Minute: $\quad 55$ 3. Date of Decommissioning. $>-11-11$

$\hat{\imath} \hat{\hat{t}}$ tocation of Water Use:

I/ North, Range $8 E \nabla w \square$, Lancaster feet from the ( $E[\square W \square)$ section line.

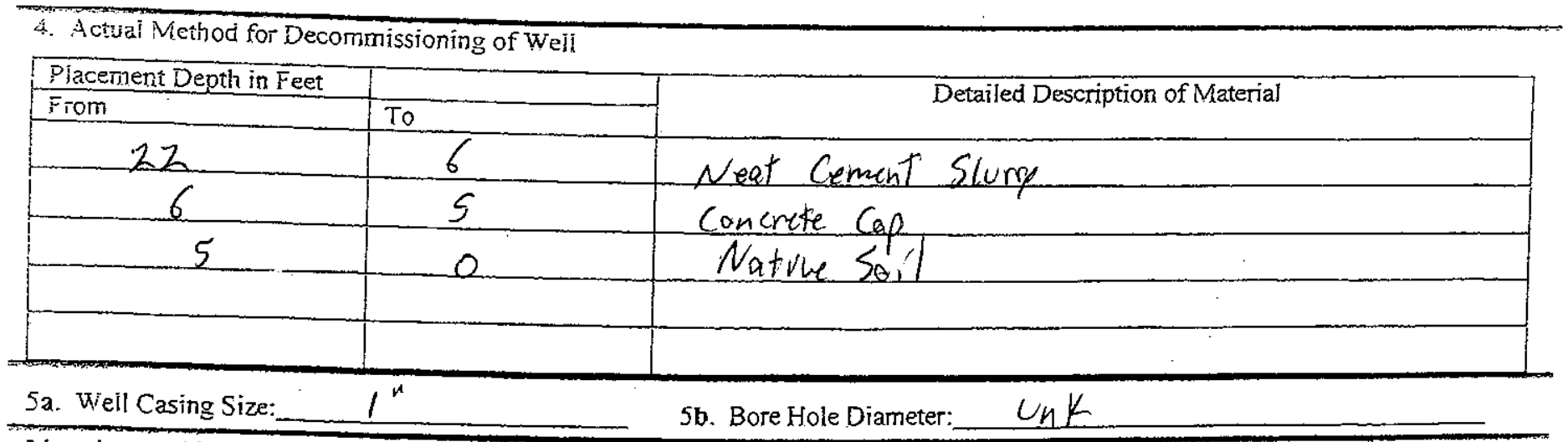

I hereby certify that the information provided on this form is true and accurate to the best of my knowiedge.

nebrter, hill zurvers Inc By?

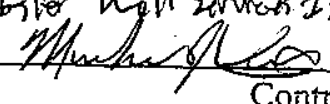

$*$ * Owner may sign on wells prior to 7/1/2001 or san Date 
Submit to:

Department of Natural Resources

301 Centeinjal Mall South

P.O. Box 0.4676

Lincoln. Nebraska 68509-4676

Phone (402) 47] 2363

STATE OF NEBRASKA

DEPARTMENT OF NATURAL RESOURCES

Oct 2007

DNR DECO

\section{NOTICE OF WATER WELL DECOMMISSIONING}

\section{FOR DEPARTMENT USE ONLY}

Date Filed $8[16) 11$ 0816 Ro11

$$
-\frac{212291}{\text { WelliD }}=\text { DECf }
$$
Owner Code No. $\quad 60538$ Registration No.

1. Well Owner's First Name

OR Company Name USDA

Last Name

Attention Name

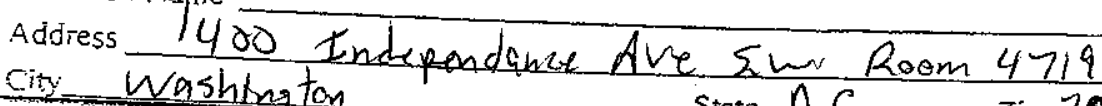 state D.C. Lip $20250 \quad$ Telephone

2. Contractor (if applicable). Webster hell Services Ine Adidress P.Q. Q 128 City Mars Bluff Emai: whsionnting State $A$ L

Telephone Number(482 666 9202 Contractor License No. 39495

3a. Weil Registration No.

36. Purpose of well:

$$
\text { o. } \mathrm{N} / \mathrm{h}
$$
Soil Cas Monitong

3. Daie Well Last Operated. LHK 3d. Date of Decommissioning.

This form is required to be filed within 60 days of decommissioning of the water well.

\section{2x. List complere well location: Legal, Footage and/or GPS Coordinates}

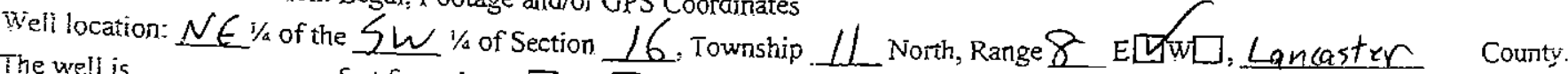

The well is feet from the (N口or $S \square$ ) section line and

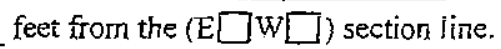

OR Latitude Degree: $\quad 40$ Longitude Degree: $\quad-96$

3f. Location of Water Use: Minute: $\quad 55$ Second: 15.59 Second: 52.09

\section{Actual Method for Decommissioning of Well}

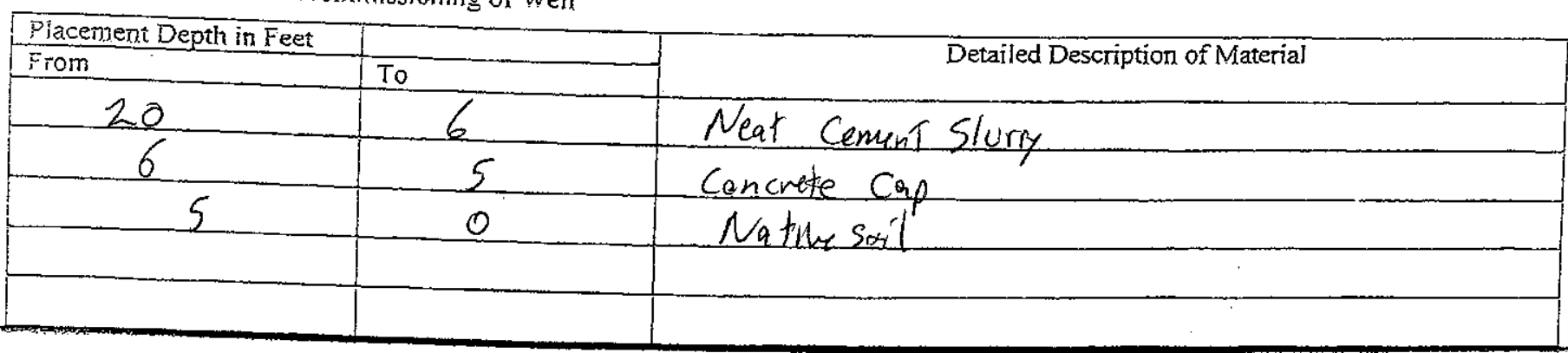

5a. Well Casing Size: $/^{r}$

5b. Bore Hole Diameter: UnK

Thereby certify that the information provided on this form is true and accurate to the best of my knowledge.

hubstat hill servoes the by:

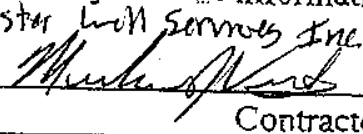


Submit to:

Depariment of Natural Resources

inl Centennial Mall South

P.O. Box 0.4676

Limcoln. Nebraska 68509-4676

Phone (402) 47) 2363
Oct 2007

DNR DECO

STATE OF NEBRASKA

DEPARTMENT OF NATURAL RESOURCES

This form is required to be filed

within 60 days of decommissioning

of the water well.

\section{NOTTCE OF WATER WELL DECOMMUSSIONING}

\section{FOR DEPARTMENT USE ONLY}

Date Filed__ $8 / 16 / 11$

$08162011+212292$

Owner Code No. $\quad 60538$

Well ID

DECF

Registration No.

LOWER PLTIE SOUTH

NRO

1. Wail Owner's First Name

OR Company Name USOA

Last Name

Attention Name

4diress 1400 Independance Ave 3.w Room 4719

city washmation State D.C Zip 26250 Telephone

2. Contractor (if applicable). Webstor hell Services Ine Aúdress P.Q Be 128 Cisy Mers Buff

Enaii:whsionnte net

Telephone Number 4046669222

Contractor License No. 39495

32. Weil Registration No.

3 . Purpose of Well: $N / A$

3x. Date Weil Last Operated. $U_{n K}$ State_NE Zip Code $68648+$

3c. List complete well location: Legal, Footage and/or GPS Coordinates

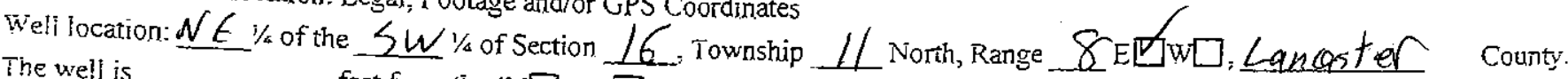

The we!l is feet from the (N口or $S \square$ ) section line and

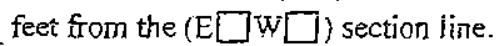
OR Latitude Degree: Longitude Degree:
40
Minute: $\frac{55}{31}$ Second: 15.29 Second: $56 \cdot 15$

35. Location of Water Use: $-\frac{-96}{N A}$

4. Actual Method for Decommissioning of Weil

\begin{tabular}{|c|c|c|}
\hline Placement Depth in Feet & \\
\hline 20 & 6 & Detailed Description of Material \\
\hline 6 & 5 & Neat Cemont Slucy \\
\hline 5 & 0 & Cencrete Coup \\
\hline & & Nathe Sor \\
\hline & & \\
\hline
\end{tabular}

5a. Well Casing Size:

$1^{n}$

5b. Bore Hole Diameter:

UnK

Thereby certify that the information provided on this form is true and accurate to the best of my knowledge.

nelbster yell Servives Ine By:
Ifta

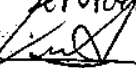
$8-\mid z \sim 11$

Contractor (**owner)

Daîe

* * Owner may sign on wells prior to $7 / 1 / 2001$ or sandpoint or if well no longer exists and it is unknown when decommissioning occurred

The Department reserves the right to request verification of information provided.

AUG 162011 
STATE OF NEBRASKA

NOTICE OF WATER WELL DECOMMUSSIONENG

\section{FOR DEPARTMENT USE ONLY}

Oct 2007

DNR DECO

This form is requited to be filed within 60 days of decommissinning of the water weil.
Date Filed $\quad 8\|\| \|$ 08162011

\section{$-\quad 212293$}

Well ID
Owner Code No.

- Decf
60538 Registration No.

LOWER PLATE SOUTH

1. Well Owner's First Name

OR Company Name USDA

Last Name

Attention Name

Address 1400 Independance Ave S.ur Room 4719

Sity wajhiton State $A_{2} C_{2}$ Zip 20250

Telephone 2. Contractor (if applicable). Webster hell Servives tome City Morse Bluff

Emaii: Wwsidentchu

3r. Weil Registration No.

3. Purpose of Weîl:

State $N E$ Zip Code 68648

\section{Date Well Last Operated. Cn K}

3e. List compleie well location: Legal, Footage and/or GPS Coordinates

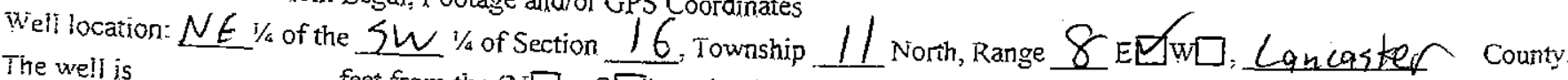
The well is feet from the (N口or $S \square$ ) section line and

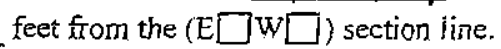
OR Latitude Degree: Longitude Degree:
40
$=96$
Minute: $\quad 55$ Second: 17.01 Minute: $\quad 3 /$ Second: 54.06

3\%. I, ocation of Water Use:_Laneaster Counh

4. Actual Method for Decommissioning of Well

\begin{tabular}{|c|c|}
\hline Placement Depth in Feet & \\
\hline From & To \\
\hline 68 & 6 \\
\hline 5 & 5 \\
\hline & 0 \\
\hline & \\
\hline
\end{tabular}

Sa. Wiell Casing Size: 8

5b. Bore Hole Diameter: UhK

I hereby certify that the information provided on this form is true and accurate to the best of my knowledge.

hibsty hey servies tine. By:

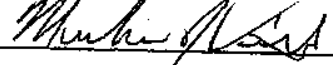

Contractor (**owner)

$8-12-11$

Buntonite Grout Slury Cencrete Cap

* * Owner may sign on wells prior to $7 / 1 / 2001$ or sandpoint or if well no longer exists and it is unknown when decommissioning occurred 


\section{NOTICE OF WATER WELL DECOMMISSIONTNG}

\section{FOR DEPARTMENT USE ONLY}

Date Filed $8 / 16) 11$ Owiner Code No.

0862011 $-\frac{212294}{\text { Well iD }}$ - DECf 60538 Registration No. LOWER PLATE SOUTH NRD

i. Well Owner's First Name

OR Company Name $U / \overline{D A}$ Last Name

Attention Name

Adress 1400 Independance Ave Sw Ream 4719 cin washination State $D C$ Zip Z0250 Telephone

2. Contractor (if applicable). Webster well Servicus Bne Address Pa Bes 128 City Merse Bluff Emaii: wwsianntrant

This form is required to be filed within 60 days of decommissioning of the water weil.

3a. Well Registration No.

3. Purpose of Well: State $N \in$ Zip Code 68648 $+$

3c. Date Weil Last Operated. UnK 3d. Date of Decommissioning. $7-11 \sim 11$

3e. List complete well location: Legal, Footage and/or GPS Coordinates

Weli location: $N W^{i / 4}$ of the $\mathcal{N} E$ 1/4 of Section $/ 6$, Township The well is feet from the (N口) $\mathrm{S} \square$ ) section line and North, Range 8 E[Dw]. Lancaster County.

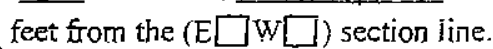
OR Latitude Degree: $\quad 40$ Longitude Degree: $\quad-96$ Minute: $\quad 55$ Second: 34.05 Minute: 31 Second: $49 \cdot 27$

3r. Location of Water Use:_Lancaster County

4. Actual Method for Decommissioning of Weil

\begin{tabular}{|c|c|c|}
\hline Piacement Deoth in Feet & & Detailed Description of Material \\
\hline 45 & To & Bentonite Grout Slurry \\
\hline 6 & 5 & Conerete $\mathrm{CaO}_{\mathrm{O}}$ \\
\hline 5 & 0 & Native Sorl \\
\hline & & 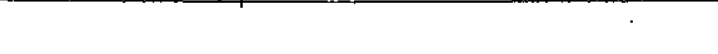 \\
\hline & & \\
\hline
\end{tabular}

5a. Well Casing Size:

10

Sb. Bore Hole Diameter:

UnK

I hereby gertify that the information provided on this form is true and accurate to the best of my knowledge.

hebstor hell servies tme $b_{y}$ : Hate 10 Contractor (**owner)

$$
8-|z-1|
$$

* * Owne" may sign on wells prior to 7/1/2001 or sandpoint or if well no longer exists and it is unknown when decommissioning ockleGEGVE 
Argonne

\section{Environmental Science Division}

Argonne National Laboratory

9700 South Cass Avenue, Bldg. 203

Argonne, IL 60439-4843

www.anl.gov 